\section{To: (Receiving Organization) \\ FFTF Engineering}

\section{Proj./Prog./Dept./Div.: \\ FFTF}

\section{Originator Remarks:}

Transmittal of HNF-1844, Transportation of Medical Isotopes
3. From: (Originating Organization)

Pacific Northwest National Laboratory

6. Design Authority/ Design Agent/Cog. Engr.:

J.C. Lavender

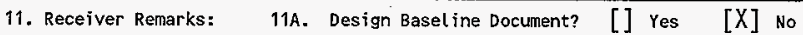

4. Related EDT No.:

$$
\mathrm{N} / \mathrm{A}
$$

7. Purchase Order No.:

$$
\mathrm{N} / \mathrm{A}
$$

9. Equip./Component No.:

$$
\mathrm{N} / \mathrm{A}
$$

10. System/Bldg./Facility: $N / A$

12. Major Assm. Dwg. No.: $N / A$

13. Permit/Permit Application No.: $N / A$

14. Required Response Date:

November 19. 1997

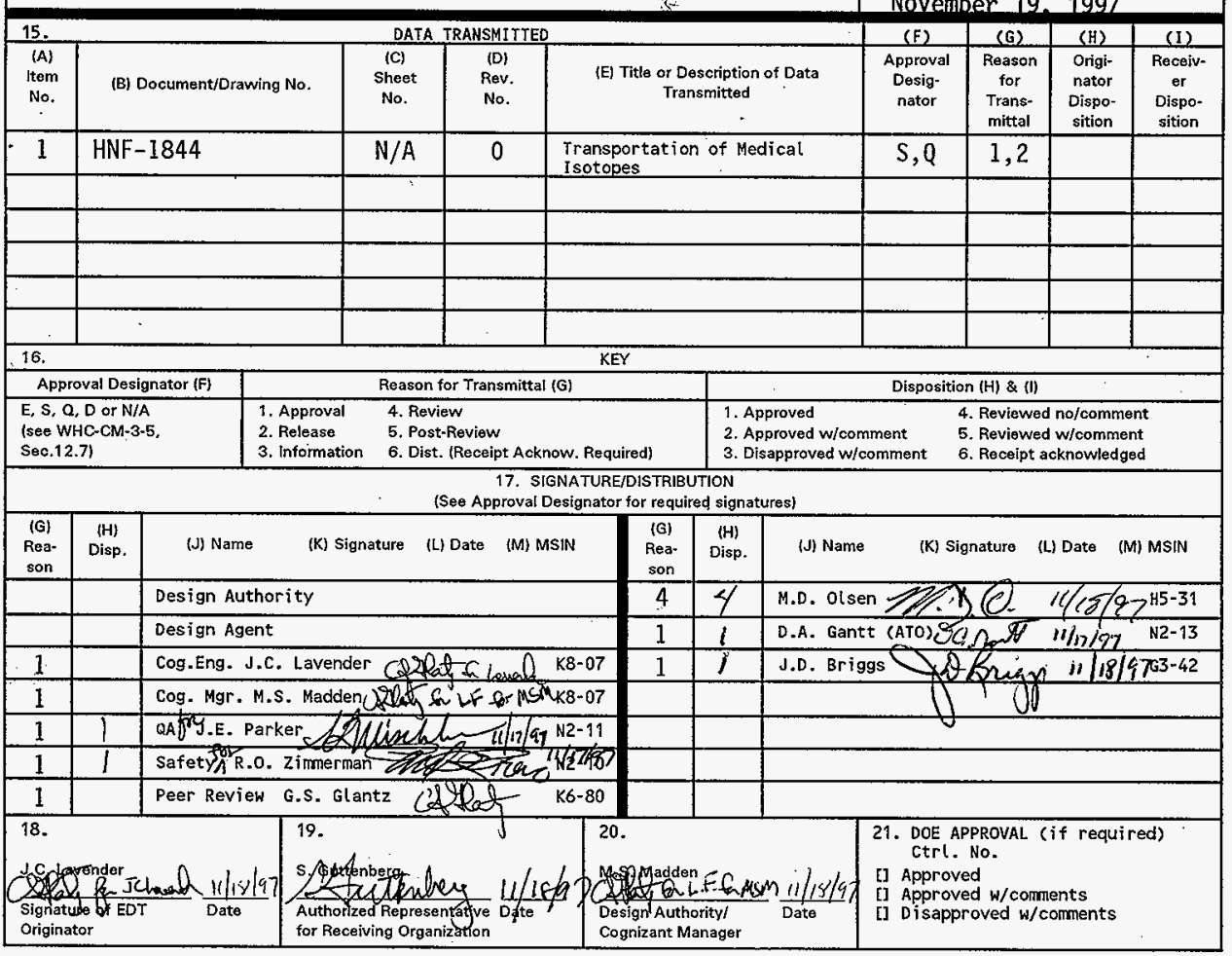




\title{
Transportation Of Medical Isotopes
}

\author{
J.C. Lavender
}

Pacific Northwest NationaT Laboratory, Richland, WA 99352

D. L. Nielsen

B \& W Hanford Company, Richland, WA 99352

U.S. Department of Energy Contract DE-AC06-96RL13200

\begin{tabular}{|c|c|c|c|}
\hline $\begin{array}{l}\text { EDT/ECN: } 6 \\
\text { Org Code: } \\
\text { B\&R Code: }\end{array}$ & $\begin{array}{l}619616 \\
18200 \\
\text { EX7002000 }\end{array}$ & $\begin{array}{l}\text { UC: } 513 \\
\text { Charge Code: } \\
\text { Total Pages: }\end{array}$ & $\begin{array}{l}\text { BE2600 } \\
92\end{array}$ \\
\hline
\end{tabular}

Key Words: Medical Isotopes, Transportation, Hanford Site, 300 Area

Abstract: A Draft Technical Information Document (HNF-1855) is being prepared to evaluate proposed interim tritium and medical isotope production at the Fast Flux Test Facility (FFTF). This assessment examines the potential health and safety impacts of transportation operations associated with the production of medical isotopes. Incident-free and accidenta 7 impacts are assessed using bounding source terms for the shipment of nonradiological target materials to the Hanford Site, the shipment of irradiated targets from the FFTF to the 325 Building, and the shipment of medical isotope products from the 325 Building to medical distributors. The health and safety consequences to workers and the public from the incident-free transportation of targets and isotope products would be within acceptable levels. For transportation accidents, risks to works and the public also would be within acceptable levels. This assessment is based on best information available at this time. As the medical isotope program matures, this analysis will be revised, if necessary, to support development of a final revision to the Technical Information Document.

TRADEMARK DISCLAIMER. Reference herein to any specific comercial product, process, or service by trade name, trademark, manufacturer, or otherwise, does not necessarily consti tute or imply its endorsement, recommendation, or favoring by the United States Government or any agency thereof or its contractors or subcontractors.

Printed in the United States of America. To obtain copies of this document, contact: Document Control Services, P.0. Box 950, Mailstop H6-08, Richland WA 99352, Phone (509) 372-2420;

Fax (509) 376-4989.
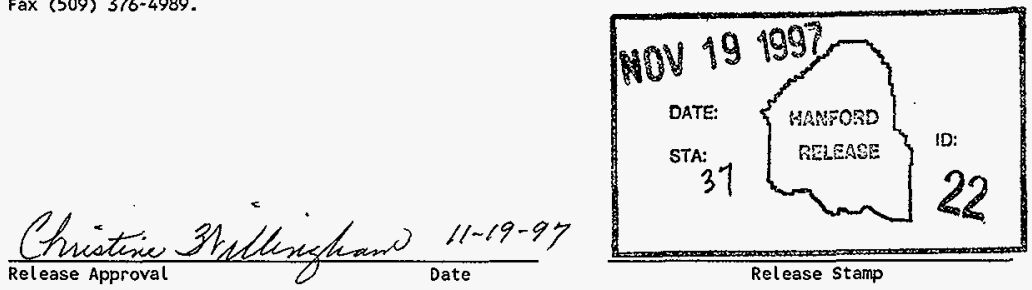

\section{Approved for Public Release}


HNF-1844, Rev. 0

\section{TRANSPORTATION OF MEDICAL ISOTOPES}

This document provides the basic information required to evaluate transportation impacts associated with the production of medical isotopes. The transportation impacts addressed here include external radiation exposures during routine transport and internal and external exposures due to vehicular accidents that result in a release of radioactive materials. Also addressed are the nonradiological impacts from routine emissions and vehicular accidents. The nonradiological routine impacts are due to pollutants emitted from the engine exhaust of the transport vehicles and the vehicular accident impacts are due to traumatic fatalities.

This evaluation addresses the shipment of enriched target materials from Oak Ridge National Laboratory (ORNL) to the Pacific Northwest National Laboratory (PNNL) for target fabrication, shipping the fabricated targets to the Fast Flux Test Facility (FFTF), shipping the irradiated targets from the FFTF to the 325 Building for target processing, and shipping isotope products to three representative pharmaceutical distributors, i.e., DupontMerck (Boston, Massachusetts), Amersham Mediphysics (Chicago, Illinois) and Mallinckrodt (St. Louis, Missouri). The shipment of isotope products would involve a combination of truck and air transportation. The isotopes would be transported from the separations facility to the Tri-Cities Airport by truck, transported by air to Salt Lake City, transferred at Salt Lake City to a non-stop connecting flight, transported by air (using direct flights) to the airport nearest the pharmaceutical distributor, and transported from the airport to the pharmaceutical distributor by truck. Passenger air service was assumed in the transportation impact analysis as a bounding assumption, as cargo air service would result in smaller impacts. During routine operations, air cargo service would be the primary air carrier for isotope products. Passenger air service would only be used to expedite urgent shipments of medical isotopes for critical research or patient treatment applications.

The next section discusses the approach used to evaluate the impacts (Section 1). Section 2 addresses the transportation requirements. The transportation system, including descriptions of the shipping casks, transporters, and routes are discussed in Section 3. The input parameters used in the transportation impact calculations are provided in Section 4 and Section 5 provides the results of the impact analyses. 


\subsection{APPROACH}

This section describes the methods used to estimate the impacts of normal and accidental exposures of individuals and populations to radioactive materials. The RADTRAN 4 (Neuhauser and Kanipe 1992) computer code was used to calculate the radiological routine and accident transportation impacts to the exposed populations, and the GENII software package (Napier et al. 1988) was used to estimate the consequences to the maximum exposed individuals.

Nonradiological incident-free and accident impacts were also evaluated. Nonradiological incident-free impacts are the potential health effects from air pollutants (e.g. NOx, CO) emitted from the engine exhaust of transport vehicles. Nonradiological accident impacts are the predicted fatalities resulting from vehicular accidents during transport activities. Neither of these two categories of impacts are related to the radiological characteristics of the cargo. Nonradiological impacts were calculated using unit risk factors (impacts per unit distance traveled) taken from Rao et al. (1982) for routine emissions and from Saricks and Kvitek (1994) for accidents.

\subsection{RADTRAN 4 Computer Code}

The RADTRAN 4 computer code (Neuhauser and Kanipe 1992) was used to perform the analyses of the radiological impacts of routine transport, and the integrated population risks of accidents during transport. RADTRAN was developed by Sandia National Laboratories (SNL) to calculate the risks associated with the transportation of radioactive materials. The original code was written by SNL in 1977 in association with the preparation of NUREG-0170, Final Environmental Statement on the Transportation of Radioactive Material by Air and Other Modes (NRC 1977). The code has since been refined and expanded and is currently maintained by SNL under contract with DOE. RADTRAN 4 is an update of the RADTRAN 3 (Madsen et al. 1986) and RADTRAN 2 (Taylor and Daniel 1982, Madsen et al. 1983) computer codes.

The RADTRAN 4 computer code is organized into the following seven models (Neuhauser and Kanipe 1992):

- material model

- transportation model

- population distribution model

- health effects model

- accident severity and package release model

- meteorological dispersion model

- economic model. 
The code uses the first three models to calculate the potential population dose from normal, incident-free transportation and the first six models are used to calculate the risk to the population from user-defined accident scenarios. The economic model is not used in this study.

1.1.1 Material Model. The material model defines the source as either a point source or as a line source. For exposure distances less than twice the package dimension, the source is conservatively assumed to be a line source. For all other cases, the source is modeled as a point source that emits radiation equally in all directions.

The material model also contains a library of 59 isotopes, each of which has 11 defining parameters that are used in the calculation of dose. The user can add isotopes not in the RADTRAN library by creating a data table in the input file consisting of the eleven parameters.

1.1.2 Transportation Model. The transportation model allows the user to input descriptions of the transportation route. A transportation route may be divided into links or segments of the journey with information for each link on population density, mode of travel (e.g., trailer truck or ship), accident rate, vehicle speed, road type, vehicle density, and link length. Alternatively, the transportation route also can be described by aggregate route data for rural, urban, and suburban areas. For this analysis, the aggregate route method was used for each potential origin-destination combination.

The HIGHWAY computer code (Johnson et al. 1993) was used to develop the transportation routing information. The information developed included aggregate population densities along the transport route and the distance traveled in each population density zone (i.e., rural, suburban and urban) for each state traversed.

1.1.3 Health Effects Model. The health effects model in RADTRAN 4 is not used and is replaced by hand calculations. The conversion factors, based on recommendations of the International Commission on Radiological Protection (ICRP 1991) for low dose, low dose rate radiological exposures were used to convert population dose to latent cancer fatalities (LCF). The health effects are determined by multiplying the integrated population dose (person-rem) calculated by RADTRAN 4 by a conversion factor to express the consequences in terms of potential latent cancer fatalities (LCF).

1.1.4 Accident Severity and Package Release Model. Accident analysis in RADTRAN 4 is performed using the accident severity and package release model. The user can define up to 20 severity categories for three population densities (urban, suburban, and rural), each increasing in magnitude. Eight severity categories for spent nuclear fuel containers that are related to fire, puncture, crush, and immersion environments are defined in NUREG-0170 (NRC 1977 and Fischer et al. 1987 ). Various other studies also have been performed for 
small packages (Clarke et al. 1976) and large packages (Dennis et al. 1978) that also can be used to generate severity categories. The accident scenarios are further defined by allowing the user to input release fractions and aerosol and respirable fractions for each severity . category. These fractions are a function of the physical-chemical properties of the materials being transported and the thermal and structural accident conditions generated within each severity category.

1.1.5 Meteorological Dispersion Model. RADTRAN 4 allows the user to choose two different methods for modeling the atmospheric transport of radionuclides after a potential accident. The user can either input Pasquill atmospheric-stability category data or averaged time-integrated concentrations. In this analysis, the dispersion of radionuclides after a potential accident is modeled by the use of time-integrated concentration values in downwind areas compiled from national averages by SNL.

1.1.6 Incident-Free Transport. The models described above are used by RADTRAN 4 to determine dose from incident-free transportation or risk (product of the accident frequencies and consequences) from potential accidents. The public and worker doses calculated by RADTRAN 4 for incident-free transportation are dependent on the type of material being transported and the transportation index (TI) of the package or packages. The TI is defined as the highest package dose rate in millirem per hour at a distance of $1 \mathrm{~m}$ from the external surface of the package. Dose consequences are also dependent on the size of the package, which as indicated in the material model description, will determine whether the exposures are modeled as a point source or line source.

1.1.7 Analysis of Potential Accidents. The accident analysis performed in RADTRAN 4 calculates population doses for each accident severity category using six exposure pathway models. They include inhalation, resuspension, groundshine, cloudshine, ingestion, and direct exposure from lost or damaged shielding. This analysis assumes that any contaminated area is either mitigated or public access controlled so there is no exposure via the ingestion pathway. The consequences calculated for each severity category are multiplied by the appropriate frequencies for accidents in each category and summed over all severity categories to give a total point estimate of risk for radiological accidents.

\subsection{GENII Description}

GENII (Napier et al. 1988), which is also referred to as the Hanford Environmental Dosimetry Software System, was developed and written by the Pacific Northwest Laboratory, to analyze radiological releases to the environment. GENII is composed of seven linked computer programs and their associated data libraries. This includes user interface programs, internal and external dose factor generators, and the environmental dosimetry programs. 
GENII is capable of:

- Calculating doses resulting from acute or chronic releases, including options for annual dose, committed dose, and accumulated dose

- Calculating doses from various exposure pathways evaluated including those through direct exposure via water, soil, and air as well as inhalation and ingestion pathways

- Acute and chronic elevated and ground level releases to air

- Acute and chronic releases to water

- Initial contamination of soil or surfaces

- Radionuclide decay.

The pathways considered in this analysis include inhalation, submersion and external exposures due to ground contamination.

\subsection{MICROSHIELD}

Microshield (Grove Engineering 1996) is used to analyze the shielding of and estimate exposures from gamma radiation. Microshield analyses are used for shielding design, container design, temporary shielding selection, source strength inference from radiation measurements, and ALARA planning. This program is a microcomputer adaptation of the main frame code ISOSHLD, a public domain "point kernel" code first written in the early 1960 's.

Microshield was used in this analysis to calculate the TI or estimated dose rate (mrem/hr) at one meter from a shipping cask. This estimated dose rate is required in RADTRAN to calculate public and worker exposures resulting from routine transportation. 


\subsection{TRANSPORTATION REQUIREMENTS}

The following sections describe the transportation requirements and assumptions used to evaluate the transportation impacts. The analysis focuses on the activities associated with transportation of the target fabrication materials, unirradiated and irradiated targets, and medical isotopes. Figure 1 provides a one-line diagram summarizing the transportation mode, the shipment origin and destination, and type of material shipped in support of the medical isotope production mission.

With the exception of the production of Actinium-227, Thorium228, and Thorium 229, this evaluation assumes that the same transportation scenario, from the target material supplier to the pharmaceutical distributor, is applicable to each isotope. That is, target materials are shipped from ORNL to PNNL, fabricated targets are shipped from PNNL to FFTF, irradiated targets are shipped from FFTF to PNNL, and the separated isotopes are shipped from PNNL to the three isotope distributors. Actinium-227, Thorium 228, and Thorium 229 are produced by irradiating a Radium-226 target. Sufficient quantities of Radium-226 would be stored at the target fabrication facility; therefore, Ra-226 target material is not shipped from ORNL to PNNL. The rest of the transport scenario from the target fabrication facility to the pharmaceutical distributor is the same as for other isotopes.

The target materials (with the exception of Radium-226) required to produce the medical isotopes are assumed to be obtained from ORNL. The target materials would be shipped on an as-needed basis from ORNL to PNNL for target fabrication. Target fabrication is assumed to occur in the 300 Area of the Hanford Site. For this analysis, it is assumed that only one target material would be shipped by truck at a time from ORNL to PNNL. This is a bounding assumption that maximizes the number of shipments, because the trucks are capable of transporting loads containing multiple types of target materials. All of the target materials received from ORNL are nonradioactive. The total shipping distance, using public highways, from ORNL to the 300 area is approximately $3,830 \mathrm{~km}(2,380$ miles). This was determined using the HIGHWAY computer code (Johnson, 1993). 


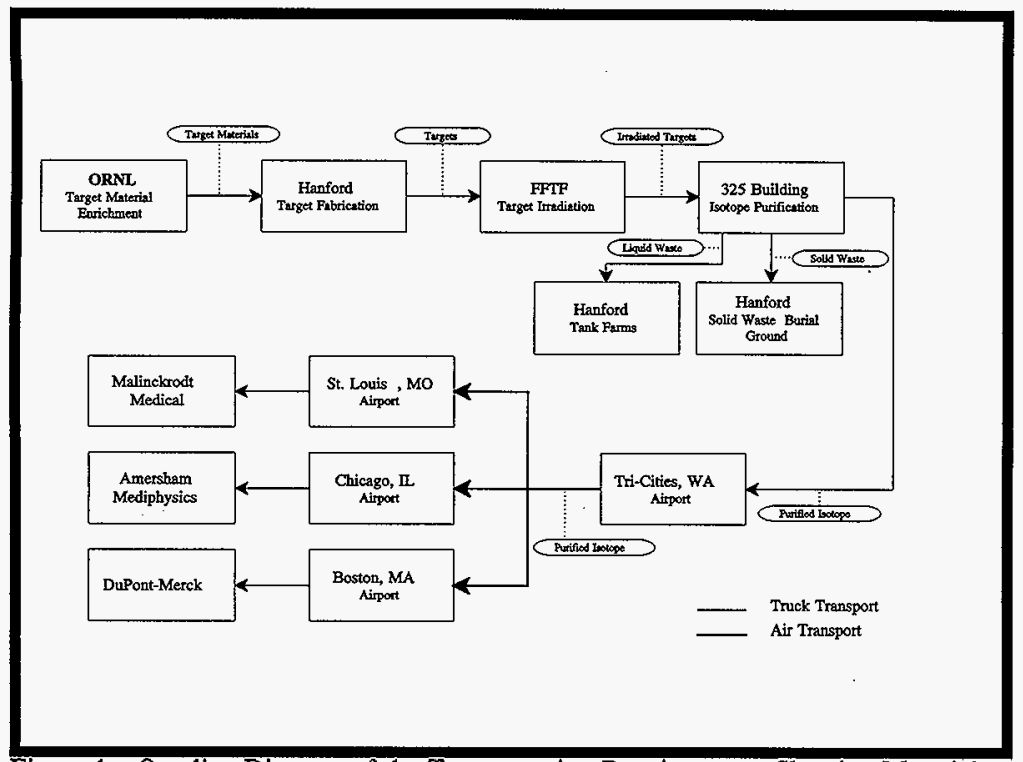

Figure 1. One-line Diagram of the Transportation Requirements, Showing Material Transported, Transportation Mode, the Shipment Origin and Destination

The target materials would be fabricated into specially- designed targets for irradiation at FFTF. The fabricated targets would be shipped by truck from either the 325 Building or 306-E Building to the FFTF. As with the target materials shipments, it was assumed that only one unirradiated target would be shipped at a time to the FFTF. The total shipping distance from the 325 Building or 306-E Building to the FFTF is approximately $14 \mathrm{~km}(8.7$ miles) and uses both Hanford Site and public roadways.

Following irradiation in the FFTF, the irradiated targets would be shipped to the 325 Building for required processing. One irradiated target was assumed to be shipped by truck at a time from the FFTF. The total shipping distance, using a combination of Hanford Site and public roadways, from the FFTF to the 325 Building is approximately $14 \mathrm{~km}(8.7$ miles). 
Following required processing and packaging, an isotope product would be shipped by truck approximately $32 \mathrm{~km}$ ( 22 miles) from the 325 Building to the Tri-Cities Airport located in Pasco, Washington. From the Tri-Cities Airport, the isotopes transported by air, using commercial passenger flights, to an intermediate airport or hub, i.e., Salt Lake City, Utah. This is a direct flight from Pasco of approximately $520 \mathrm{~km}$ (324 miles). At Salt Lake City, the isotopes are transferred to another airplane for transport to the airport nearest the pharmaceutical distributor. Using direct flights, the distance from Salt Lake City to Chicago, Illinois (Amersham Mediphysics) is 1,257 km (780 miles), to Boston, Massachusetts (Dupont-Merck) is 2,105 km (1310 miles) and to St. Louis, Missouri (Mallinckrodt) is 1,156 $\mathrm{km}$ (720 miles).

The isotope product is transported from the destination airport (e.g., St. Louis, Missouri) to the pharmaceutical distributor by truck, using public roadways. For shipments to DupontMerck facility located in Billerica, Massachusetts, the package containing an isotope product would be transported $35 \mathrm{~km}$ ( 22 miles). For shipments to Amersham Mediphysics facility located in Arlington Heights, Illinois, the package containing the isotope product would be transported $32 \mathrm{~km}$ (20 miles). For shipments to the Mallinckrodt facility located in Hazelwood, Missouri, the package containing the separated medical isotopes is transported $13 \mathrm{~km}$ (8 miles).

The radiological inventories for each irradiated target and isotope product are shown in Table 1. This analysis includes the shipment of each isotope target from the 300 area to FFTF, irradiated targets from FFTF to the 325 Building, and separated isotope shipments from the 325 Building to the Tri-Cities Airport, from the Tri-Cities Airport to the destination airport (e.g., Chicago Airport), and from the destination airport to the pharmaceutical distributor (e.g., Chicago Airport to Amersham Mediphysics). Table 2 provides the source term for the activated target cladding or retrieval hardware associated with the irradiated target shipments from FFTF to the 325 Building. Table 3 provides the source term for shipments of waste (i.e., liquid processing waste and solid waste, including spent target hulls and miscellaneous wastes), to the 200 East and West Areas for subsequent storage and/or disposal. 
HNF-1844, Rev. 0

Table 1. Radiological Source Terms Used in this Analysis for the Irradiated Targets and Separated Medical Isotopes

\begin{tabular}{|c|c|c|c|c|}
\hline \multirow[t]{2}{*}{ Product Isotope } & \multirow{2}{*}{$\begin{array}{l}\text { Estimated Annual } \\
\text { Number of } \\
\text { Shipments of } \\
\text { Irradiated Targets } \\
\text { and Separated } \\
\text { Isotopes }\end{array}$} & \multirow{2}{*}{$\begin{array}{l}\text { Radionuclide } \\
\text { Shipped }\end{array}$} & \multicolumn{2}{|c|}{ Quantity Shipped (Ci/Shipment) } \\
\hline & & & $\begin{array}{l}\text { Irradiated Targets } \\
\text { to } 325 \text { Building }\end{array}$ & Isotope $^{\text {(a) }}$ \\
\hline \multirow[t]{10}{*}{ Ac227 } & \multirow[t]{10}{*}{1} & Ac227 & $2.0 \mathrm{E}+02$ & $2.0 \mathrm{E}+02$ \\
\hline & & Th227 (b) & $1.9 \mathrm{E}+02$ & $1.0 \mathrm{E}+02$ \\
\hline & & Th228 $8^{(\text {) }}$ & $2.1 \mathrm{E}+03$ & $1.0 \mathrm{E}+03$ \\
\hline & & $\operatorname{Th} 229^{(b)}$ & $1.6 \mathrm{E}-01$ & $4.0 \mathrm{E}-02$ \\
\hline & & $\mathrm{Ra} 226$ & $2.6 \mathrm{E}+01$ & Recycled \\
\hline & & $\mathrm{Ra} 227$ & $1.1 \mathrm{E}-06$ & Recycled \\
\hline & & $\operatorname{Ra} 228$ & $1.5 \mathrm{E}-02$ & Recycled \\
\hline & & $\mathrm{Ra} 229$ & $3.8 \mathrm{E}-13$ & Recycled \\
\hline & & $\mathrm{Ac} 228$ & $4.5 \mathrm{E}-02$ & Waste \\
\hline & & Ac229 & $3.8 \mathrm{E}-13$ & Waste \\
\hline \multirow[t]{7}{*}{ Au198 } & \multirow[t]{7}{*}{25} & Au198 & $1.8 \mathrm{E}+02$ & $1.8 \mathrm{E}+02$ \\
\hline & & Au196 & $2.1 \mathrm{E}-02$ & $2.1 \mathrm{E}-02$ \\
\hline & & Au $198 \mathrm{~m}$ & $1.3 \mathrm{E}+02$ & $1.3 \mathrm{E}+02$ \\
\hline & & Au199 & $3.4 \mathrm{E}+02$ & $3.4 \mathrm{E}+02$ \\
\hline & & Au $200 \mathrm{~m}$ & $1.2 \mathrm{E}-01$ & $1.2 \mathrm{E}-01$ \\
\hline & & $A u 200$ & $4.1 \mathrm{E}-02$ & $4.1 \mathrm{E}-02$ \\
\hline & & Pt197 & $1.2 \mathrm{E}-05$ & $1.2 \mathrm{E}-05$ \\
\hline \multirow[t]{6}{*}{ Cd109 } & \multirow[t]{6}{*}{1} & Cd109 & $7.9 \mathrm{E}+03$ & $7.9 \mathrm{E}+03$ \\
\hline & & Cd107 & 1.1E-01 & Waste \\
\hline & & Ag105 & $8.8 \mathrm{E}-01$ & Waste \\
\hline & & Ag106m & $3.9 \mathrm{E}-03$ & Waste \\
\hline & & $\operatorname{Ag} 107 \mathrm{~m}$ & $1.1 \mathrm{E}-01$ & Waste \\
\hline & & Ag108m & 4. 3E-02 & Waste \\
\hline
\end{tabular}


HNF-1844, Rev. 0

Table 1. Radiological Source Terms Used in this Analysis for the Irradiated Targets and Separated Medical Isotopes

\begin{tabular}{|c|c|c|c|c|}
\hline \multirow[t]{7}{*}{ Product Isotope } & \multirow{7}{*}{$\begin{array}{l}\text { Estimated Annual } \\
\text { Number of } \\
\text { Shipments of } \\
\text { Irradiated Targets } \\
\text { and Separated } \\
\text { Isotopes }\end{array}$} & Radionuclide & \multicolumn{2}{|c|}{ Quantity Shipped (Ci/Shipment) } \\
\hline & & & $\begin{array}{l}\text { Irradiated Targets } \\
\text { to } 325 \text { Building }\end{array}$ & Isotope ${ }^{(a)}$ \\
\hline & & Ag108 & $3.8 \mathrm{E}-03$ & Waste \\
\hline & & $\mathrm{Ag} 110 \mathrm{~m}$ & $4.8 \mathrm{E}+01$ & Waste \\
\hline & & $\operatorname{Ag} 110$ & $6.7 \mathrm{E}-01$ & Waste \\
\hline & & Ag111 & $7.7 \mathrm{E}-06$ & Waste \\
\hline & & Pd109 & $1.6 \mathrm{E}-03$ & Waste \\
\hline \multirow[t]{3}{*}{ Cu64 } & \multirow[t]{3}{*}{25} & Cu64 & $2.2 \mathrm{E}+01$ & $2.2 \mathrm{E}+01^{\circ}$ \\
\hline & & Zn65 & $2.5 \mathrm{E}+00$ & Waste \\
\hline & & $\mathrm{Cu} 67$ & 2.1E-03 & Waste \\
\hline \multirow[t]{4}{*}{ Cu67 } & \multirow[t]{4}{*}{25} & $\mathrm{Cu} 67$ & $8.3 E+00$ & $8.3 \mathrm{E}+00^{\circ}$ \\
\hline & & Zn65 & $1.2 \mathrm{E}-03$ & Waste \\
\hline & & $\mathrm{Zn} 69 \mathrm{~m}$ & $3.6 \mathrm{E}+00$ & Waste \\
\hline & & Zn69 & $1.4 \mathrm{E}+01$ & Waste \\
\hline \multirow[t]{8}{*}{ Gd153 } & \multirow[t]{8}{*}{1} & Gd153 & $6.1 E+03$ & $6.1 \mathrm{E}+03$ \\
\hline & & Eu $152 \mathrm{~m}$ & $2.3 \mathrm{E}-05$ & Waste \\
\hline & & Eu152 & $3.3 \mathrm{E}+03$ & Waste \\
\hline & & Eu154m & 3.1E-05 & Waste \\
\hline & & Eu154 & $1.8 \mathrm{E}+04$ & Waste \\
\hline & & Eu155 & $6.1 E+03$ & Waste \\
\hline & & Eu156 & $8.3 E+04$ & Waste \\
\hline & & Sm153 & $6.4 \mathrm{E}-05$ & Waste \\
\hline \multirow[t]{3}{*}{ Ho166 } & \multirow[t]{3}{*}{25} & Ho166 & $4.0 \mathrm{E}+01$ & $4.0 \mathrm{E}+01$ \\
\hline & & Hol66m & $3.8 \mathrm{E}-05$ & $3.8 \mathrm{E}-05$ \\
\hline & & Hol67 & $9.7 \mathrm{E}-03$ & $9.7 \mathrm{E}-03$ \\
\hline
\end{tabular}


HNF-1844, Rev. 0

Table 1. Radiological Source Terms Used in this Analysis for the Irradiated Targets and Separated Medical Isotopes

\begin{tabular}{|c|c|c|c|c|}
\hline \multirow[t]{4}{*}{ Product Isotope } & \multirow{4}{*}{$\begin{array}{l}\text { Estimated Annual } \\
\text { Number of } \\
\text { Shipments of } \\
\text { Irradiated Targets } \\
\text { and Separated } \\
\text { Isotopes }\end{array}$} & \multirow{2}{*}{$\begin{array}{l}\text { Radionuclide } \\
\text { Shipped }\end{array}$} & \multicolumn{2}{|c|}{ Quantity Shipped (Ci/Shipment) } \\
\hline & & & $\begin{array}{l}\text { Irradiated Targets } \\
\text { to } 325 \text { Building }\end{array}$ & Isotope ${ }^{(a)}$ \\
\hline & & Er167m & $9.7 \mathrm{E}-03$ & $9.7 \mathrm{E}-03$ \\
\hline & & Dy 166 & $9.6 \mathrm{E}-07$ & $9.6 \mathrm{E}-07$ \\
\hline \multirow[t]{4}{*}{1125} & \multirow[t]{4}{*}{1} & I125 & $1.4 \mathrm{E}+04$ & $1.4 \mathrm{E}+04$ \\
\hline & & $\mathrm{Xe125}$ & $1.4 \mathrm{E}+04$ & Waste \\
\hline & & 1124 & $5.9 \mathrm{E}-01$ & Waste \\
\hline & & $\mathrm{I} 126$ & $2.4 \mathrm{E}+02$ & Waste \\
\hline \multirow[t]{6}{*}{$I 131$} & \multirow[t]{6}{*}{10} & I131 & $6.0 \mathrm{E}+02$ & $6.0 \mathrm{E}+02$ \\
\hline & & $\mathrm{Te} 129 \mathrm{~m}$ & $1.1 \mathrm{E}+01$ & Waste \\
\hline & & Te129 & $8.8 \mathrm{E}+01$ & Waste \\
\hline & & $\mathrm{Te} 131$ & $6.7 E+02$ & Waste \\
\hline & & 1129 & $1.1 \mathrm{E}-06$ & Waste \\
\hline & & 1130 & $2.2 \mathrm{E}+00$ & Waste \\
\hline \multirow[t]{8}{*}{ Ir19.2 } & \multirow[t]{8}{*}{1} & Ir192 & $2.0 \mathrm{E}+06$ & $2.0 \mathrm{E}+06$ \\
\hline & & $\operatorname{Ir} 192 \mathrm{~m}$ & $2.8 \mathrm{E}+01$ & $2.8 \mathrm{E}+01$ \\
\hline & & Ir $193 \mathrm{~m}$ & $1.6 \mathrm{E}+04$ & $1.6 \mathrm{E}+04$ \\
\hline & & Ir $194 \mathrm{~m}$ & $6.8 \mathrm{E}+03$ & $6.8 \mathrm{E}+03$ \\
\hline & & Ir194 & $2.8 \mathrm{E}+02$ & $2.8 \mathrm{E}+02$ \\
\hline & & Pt193m & $2.2 \mathrm{E}+03$ & $2.2 \mathrm{E}+03$ \\
\hline & & Pt193 & $2.8 \mathrm{E}+01$ & $2.8 \mathrm{E}+01$ \\
\hline & & Pt195m & $1.5 \mathrm{E}+02$ & $1.5 \mathrm{E}+02$ \\
\hline \multirow[t]{3}{*}{ Lu177 } & \multirow[t]{3}{*}{10} & Lu177 & $9.8 \mathrm{E}+00$ & $9.8 \mathrm{E}+00^{\circ}$ \\
\hline & & $\mathrm{Lu} 176 \mathrm{~m}$ & $1.1 \mathrm{E}+00$ & Waste \\
\hline & & Lul77m & $1.1 \mathrm{E}-03$ & Waste \\
\hline
\end{tabular}


HNF-1844, Rev. 0

Table 1. Radiological Source Terms Used in this Analysis for the Irradiated Targets and Separated Medical Isotopes

\begin{tabular}{|c|c|c|c|c|}
\hline \multirow[t]{7}{*}{ Product Isotope } & \multirow{7}{*}{$\begin{array}{l}\text { Estimated Annual } \\
\text { Number of } \\
\text { Shipments of } \\
\text { Irradiated Targets } \\
\text { and Separated } \\
\text { Isotopes }\end{array}$} & \multirow{2}{*}{$\begin{array}{c}\text { Radionuclide } \\
\text { Shipped }\end{array}$} & \multicolumn{2}{|c|}{ Quantity Shipped (Ci/Shipment) } \\
\hline & & & $\begin{array}{l}\text { Irradiated Targets } \\
\text { to } 325 \text { Building }\end{array}$ & Isotope ${ }^{(a)}$ \\
\hline & & Lu178 & $3.2 \mathrm{E}-04$ & Waste \\
\hline & & Lu179 & $5.5 \mathrm{E}-08$ & Waste \\
\hline & & $\mathrm{Hf} 177 \mathrm{~m}$ & $1.4 \mathrm{E}-03$ & Waste \\
\hline & & Hf178m & $1.9 \mathrm{E}-05$ & Waste \\
\hline & & $\mathrm{Hf} 179 \mathrm{~m}$ & $1.5 \mathrm{E}-05$ & Waste \\
\hline \multirow[t]{5}{*}{ Mo99 } & \multirow[t]{5}{*}{25} & Mo99 & $1.2 \mathrm{E}+04$ & $1.2 \mathrm{E}+04$ \\
\hline & & Mo101 & $2.0 \mathrm{E}+00$ & $2.0 \mathrm{E}+00$ \\
\hline & & $\mathrm{Tc} 99 \mathrm{~m}$ & $7.6 \mathrm{E}+03$ & $7.6 \mathrm{E}+03$ \\
\hline & & Tc99 & $3.1 \mathrm{E}-04$ & $3.1 \mathrm{E}-04$ \\
\hline & & Tc101 & $1.5 \mathrm{E}+01$ & $1.5 \mathrm{E}+01$ \\
\hline \multirow[t]{8}{*}{ Os194 } & \multirow[t]{8}{*}{1} & Os194 & $2.6 \mathrm{E}+01$ & $2.6 \mathrm{E}+01$ \\
\hline & & Os $191 \mathrm{~m}$ & $5.0 \mathrm{E}+02$ & Waste \\
\hline & & Os191 & $3.3 E+05$ & Waste \\
\hline & & Os193 & $1.5 \mathrm{E}+05$ & Waste \\
\hline & & Ir192 & $1.1 \mathrm{E}+03$ & Waste \\
\hline & & Ir $193 m$ & $1.1 \mathrm{E}+01$ & Waste \\
\hline & & Ir 194m & $1.5 \mathrm{E}-03$ & Waste \\
\hline & & Ir194 & $2.6 \mathrm{E}+01$ & Waste \\
\hline \multirow[t]{3}{*}{ P32 } & \multirow[t]{3}{*}{5} & P32 & $1.6 \mathrm{E}+02$ & $1.6 \mathrm{E}+02$ \\
\hline & & S35 & $3.3 \mathrm{E}+01$ & Waste \\
\hline & & P33 & $4.0 \mathrm{E}-01$ & Waste \\
\hline \multirow[t]{2}{*}{ P33 } & \multirow[t]{2}{*}{3} & P33 & $2.0 \mathrm{E}+02$ & $2.0 \mathrm{E}+02$ \\
\hline & & \$35 & $2.3 \mathrm{E}+01$ & Waste \\
\hline
\end{tabular}


HNF-1844, Rev. 0

Table 1. Radiological Source Terms Used in this Analysis for the Irradiated Targets and Separated Medical Isotopes

\begin{tabular}{|c|c|c|c|c|}
\hline \multirow[t]{3}{*}{ Product Isotope } & \multirow{3}{*}{$\begin{array}{l}\text { Estimated Annual } \\
\text { Number of } \\
\text { Shipments of } \\
\text { Irradiated Targets } \\
\text { and Separated } \\
\text { Isotopes }\end{array}$} & \multirow{2}{*}{$\begin{array}{c}\text { Radionuclide } \\
\text { Shipped }\end{array}$} & \multicolumn{2}{|c|}{ Quantity Shipped (Ci/Shipment) } \\
\hline & & & $\begin{array}{l}\text { Irradiated Targets } \\
\text { to } 325 \text { Building }\end{array}$ & Isotope ${ }^{(a)}$ \\
\hline & & P32 & $5.2 E+00$ & Waste \\
\hline \multirow[t]{4}{*}{ Pd103 } & \multirow[t]{4}{*}{5} & Pd103 & $5.5 E+03$ & $5.5 \mathrm{E}+03$ \\
\hline & & $\mathrm{Rh} 103 \mathrm{~m}$ & $5.5 \mathrm{E}+03$ & $5.5 \mathrm{E}+03$ \\
\hline & & Rh105 & $8.8 \mathrm{E}-05$ & $8.8 \mathrm{E}-05$ \\
\hline & & Ag107m & $4.8 \mathrm{E}-05$ & $4.8 \mathrm{E}-05$ \\
\hline \multirow[t]{8}{*}{ Pt195m } & \multirow[t]{8}{*}{5} & Pt195m & $4.5 \mathrm{E}+00$ & $4.5 \mathrm{E}+00$ \\
\hline & & Pt193m & $8.8 \mathrm{E}+00$ & $8.8 \mathrm{E}+00$ \\
\hline & & Pt193 & $1.4 \mathrm{E}-01$ & $1.4 \mathrm{E}-01$ \\
\hline & & Pt197 & $8.6 \mathrm{E}+01$ & $8.6 \mathrm{E}+01$ \\
\hline & & Ir193m & $1.1 \mathrm{E}-01$ & $1.1 \mathrm{E}-01$ \\
\hline & & Ir $194 \mathrm{~m}$ & $1.8 \mathrm{E}-04$ & $1.8 \mathrm{E}-04$ \\
\hline & & Ir194 & 4.2E-05 & $4.2 \mathrm{E}-05$ \\
\hline & & Au $197 \mathrm{~m}$ & $8.6 \mathrm{E}+01$ & $8.6 \mathrm{E}+01$ \\
\hline \multirow[t]{7}{*}{$\operatorname{Re} 186$} & \multirow[t]{7}{*}{10} & $\operatorname{Re} 186$ & $7.0 \mathrm{E}+03$ & $7.0 \mathrm{E}+03$ \\
\hline & & $\operatorname{Re} 186 \mathrm{~m}$ & $1.7 \mathrm{E}-03$ & $1.7 \mathrm{E}-03$ \\
\hline & & $\operatorname{Re} 188$ & $4.8 \mathrm{E}+02$ & $4.8 \mathrm{E}+02$ \\
\hline & & $\operatorname{Re} 189$ & $9.3 \mathrm{E}-02$ & $9.3 \mathrm{E}-02$ \\
\hline & & Os $189 \mathrm{~m}$ & $4.0 \mathrm{E}+00$ & $4.0 \mathrm{E}+00$ \\
\hline & & W187 & $3.7 \mathrm{E}-01$ & 3.7E-01 \\
\hline & & W188 & $1.2 \mathrm{E}-09$ & $1.2 \mathrm{E}-09$ \\
\hline \multirow[t]{3}{*}{ Sc47 } & \multirow[t]{3}{*}{25} & Sc47 & $4.0 \mathrm{E}+01$ & $4.0 \mathrm{E}+01$ \\
\hline & & Sc46 & $1.5 \mathrm{E}-02$ & Waste \\
\hline & & Sc48 & $5.6 \mathrm{E}-02$ & Waste \\
\hline
\end{tabular}


HNF-1844, Rev. 0

Table 1. Radiological Source Terms Used in this Analysis for the Irradiated Targets and Separated Medical Isotopes

\begin{tabular}{|c|c|c|c|c|}
\hline \multirow[t]{3}{*}{ Product Isotope } & \multirow{3}{*}{$\begin{array}{l}\text { Estimated Annual } \\
\text { Number of } \\
\text { Shipments of } \\
\text { Irradiated Targets } \\
\text { and Separated } \\
\text { Isotopes }\end{array}$} & \multirow{2}{*}{$\begin{array}{l}\text { Radionuclide } \\
\text { Shipped }\end{array}$} & \multicolumn{2}{|c|}{ Quantity Shipped (Ci/Shipment) } \\
\hline & & & $\begin{array}{l}\text { Irradiated Targets } \\
\text { to } 325 \text { Building }\end{array}$ & Isotope ${ }^{\text {(a) }}$ \\
\hline & & $\mathrm{Ca} 47$ & $2.3 \mathrm{E}-05$ & Waste \\
\hline \multirow[t]{3}{*}{ Se75 } & \multirow[t]{3}{*}{1} & Se75 & $9.9 \mathrm{E}+01$ & $9.9 \mathrm{E}+01$ \\
\hline & & As76 & 4.7E-02 & 4.7E-02 \\
\hline & & As77 & $4.0 \mathrm{E}-05$ & $4.0 \mathrm{E}-05$ \\
\hline \multirow[t]{10}{*}{ Sm145 } & \multirow[t]{10}{*}{1} & Sm145 & $1.0 \mathrm{E}+02$ & $1.0 \mathrm{E}+02^{\circ}$ \\
\hline & &. $\mathrm{Sm} 146$ & $5.5 \mathrm{E}-07$ & 5.5E-07 \\
\hline & & Sm151 & $1.7 \mathrm{E}-01$ & $1.7 \mathrm{E}-01$ \\
\hline & & Pm145 & $2.1 E+00$ & $2.1 \mathrm{E}+00$ \\
\hline & & $\operatorname{Pm} 146$ & $1.2 \mathrm{E}-01$ & $1.2 \mathrm{E}-01$ \\
\hline & & Pm147 & $2.8 \mathrm{E}-03$ & $2.8 \mathrm{E}-03$ \\
\hline & & Pm148m & $1.9 \mathrm{E}-03$ & $1.9 \mathrm{E}-03$ \\
\hline & & Pm148 & $4.2 \mathrm{E}-03$ & $4.2 \mathrm{E}-03$ \\
\hline & & Pm149 & $1.5 \mathrm{E}-03$ & $1.5 \mathrm{E}-03$ \\
\hline & & $\mathrm{Nd} 147$ & $4.6 \mathrm{E}-04$ & 4.6E-04 \\
\hline \multirow[t]{9}{*}{ Sm153 } & \multirow[t]{9}{*}{25} & Sm153 & $8.0 \mathrm{E}+01$ & $8.0 \mathrm{E}+01$ \\
\hline & & $\operatorname{Sm} 151$ & $2.0 \mathrm{E}-06$ & $2.0 \mathrm{E}-06$ \\
\hline & & $\operatorname{Sm} 155$ & 4.1E-04 & 4.1E-04 \\
\hline & & Sm156 & $1.2 \mathrm{E}-07$ & $1.2 \mathrm{E}-07$ \\
\hline & & $\mathrm{Eu} 152 \mathrm{~m}$ & $5.0 \mathrm{E}-08$ & $5.0 \mathrm{E}-08$ \\
\hline & & Eu154m & $2.0 \mathrm{E}-01$ & $2.0 \mathrm{E}-01$ \\
\hline & & Eu154 & $3.0 \mathrm{E}-03$ & $3.0 \mathrm{E}-03$ \\
\hline & & Eu155 & $3.1 \mathrm{E}-04$ & $3.1 \mathrm{E}-04$ \\
\hline & & Eu156 & $8.6 \mathrm{E}-03$ & $8.6 \mathrm{E}-03$ \\
\hline
\end{tabular}


HNF-1844, Rev. 0

Table 1. Radiological Source Terms Used in this Analysis for the Irradiated Targets and Separated Medical Isotopes

\begin{tabular}{|c|c|c|c|c|}
\hline \multirow[t]{2}{*}{ Product Isotope } & \multirow{2}{*}{$\begin{array}{l}\text { Estimated Annual } \\
\text { Number of } \\
\text { Shipments of } \\
\text { Irradiated Targets } \\
\text { and Separated } \\
\text { Isotopes }\end{array}$} & \multirow{2}{*}{$\begin{array}{l}\text { Radionuclide } \\
\text { Shipped }\end{array}$} & \multicolumn{2}{|c|}{ Quantity Shipped (Ci/Shipment) } \\
\hline & & & $\begin{array}{l}\text { Irradiated Targets } \\
\text { to } 325 \text { Building }\end{array}$ & Isotope ${ }^{\text {(a) }}$ \\
\hline \multirow[t]{2}{*}{$\mathrm{Sn} 117 \mathrm{~m}$} & \multirow[t]{2}{*}{5} & $\mathrm{Sn} 117 \mathrm{~m}$ & $2.0 \mathrm{E}+02$ & $2.0 \mathrm{E}+02$ \\
\hline & & $\operatorname{Sn} 119 \mathrm{~m}$ & 1.7E-02 & $1.7 \mathrm{E}-02$ \\
\hline \multirow[t]{6}{*}{ Sr85 } & \multirow[t]{6}{*}{1} & Sr85 & $4.9 \mathrm{E}+02$ & $4.9 \mathrm{E}+02$ \\
\hline & & Sr89 & $6.5 \mathrm{E}-02$ & $6.5 \mathrm{E}-02$ \\
\hline & & $\operatorname{Sr} 90$ & $5.4 \mathrm{E}-06$ & $5.4 \mathrm{E}-06$ \\
\hline & & $\mathrm{Rb} 84$ & $1.3 \mathrm{E}+00$ & $1.3 \mathrm{E}+00$ \\
\hline & & $\mathrm{Rb} 86$ & $3.0 \mathrm{E}+00$ & $3.0 \mathrm{E}+00$ \\
\hline & & Kr85 & $4.2 \mathrm{E}-05$ & $4.2 \mathrm{E}-05$ \\
\hline \multirow[t]{6}{*}{ Sr89 } & \multirow[t]{6}{*}{3} & Sr89 & $3.9 E+02$ & $3.9 \mathrm{E}+02$ \\
\hline & & $\mathrm{Sr} 85$ & 4. $6 \mathrm{E}-03$ & Waste \\
\hline & & Sr90 & 2.5E-02 & Waste \\
\hline & & $\mathrm{Rb} 86$ & $5.1 \mathrm{E}-06$ & Waste \\
\hline & & Y88 & 7.9E-06 & Waste \\
\hline & & Y90 & $1.5 \mathrm{E}+00$ & Waste \\
\hline \multirow[t]{9}{*}{ W188 } & \multirow[t]{9}{*}{1} & W188 & $3.3 \mathrm{E}+04$ & $3.3 \mathrm{E}+04$ \\
\hline & & W181 & $2.8 \mathrm{E}-03$ & $2.8 \mathrm{E}-03$ \\
\hline & & W185 & $9.2 \mathrm{E}+04$ & $9.2 \mathrm{E}+04$ \\
\hline & & W187 & $1.8 \mathrm{E}+05$ & $1.8 \mathrm{E}+05$ \\
\hline & & Ta182 & $1.2 \mathrm{E}-05$ & $1.2 \mathrm{E}-05$ \\
\hline & & Ta183 & $8.0 \mathrm{E}-05$ & $8.0 \mathrm{E}-05$ \\
\hline & & $\operatorname{Re} 186 \mathrm{~m}$ & $4.6 \mathrm{E}-03$ & 4.6E-03 \\
\hline & & $\operatorname{Re} 186$ & $4.8 \mathrm{E}+03$ & $4.8 \mathrm{E}+03$ \\
\hline & & Re188m & $1.6 \mathrm{E}-06$ & $1.6 \mathrm{E}-06$ \\
\hline
\end{tabular}


HNF-1844, Rev. 0

Table 1. Radiological Source Terms Used in this Analysis for the Irradiated Targets and Separated Medical Isotopes

\begin{tabular}{|c|c|c|c|c|}
\hline \multirow[t]{5}{*}{ Product Isotope } & \multirow{5}{*}{$\begin{array}{l}\text { Estimated Annual } \\
\text { Number of } \\
\text { Shipments of } \\
\text { Irradiated Targets } \\
\text { and Separated } \\
\text { Isotopes }\end{array}$} & Radionuclide & \multicolumn{2}{|c|}{ Quantity Shipped (Ci/Shipment) } \\
\hline & & & $\begin{array}{l}\text { Irradiated Targets } \\
\text { to } 325 \text { Building }\end{array}$ & Isotope ${ }^{(a)}$ \\
\hline & & $\operatorname{Re} 188$ & $4.0 \mathrm{E}+04$ & $4.0 \mathrm{E}+04$ \\
\hline & & $\operatorname{Re} 189$ & $2.7 \mathrm{E}+01$ & $2.7 \mathrm{E}+01$ \\
\hline & & Os $189 \mathrm{~m}$ & $3.5 \mathrm{E}+01$ & $3.5 \mathrm{E}+01$ \\
\hline $\mathrm{Xe} 127$ & 3 & $\mathrm{Xe} 127$ & $2.0 \mathrm{E}+02$ & $2.0 \mathrm{E}+02$ \\
\hline \multirow[t]{5}{*}{ Y91 } & \multirow[t]{5}{*}{1} & Y91 & $9.9 \mathrm{E}+01$ & $9.9 \mathrm{E}+01$ \\
\hline & & $\mathrm{Zr} 89$ & $7.8 \mathrm{E}-01$ & Waste \\
\hline & & Zr93 & $5.8 \mathrm{E}-04$ & Waste \\
\hline & & $\mathrm{Zr95}$ & $2.1 \mathrm{E}-02$ & Waste \\
\hline & & Y90 & $3.2 \mathrm{E}+00$ & Waste \\
\hline
\end{tabular}

(a) Recycled - Radioactive material will be recycled for further use in targets

Waste - Material is not shipped as part of separated isotope and is treated as liquid and solid waste.

(b) Th-227, Th-228, and Th-229 are isotopes generated during the irradiation of the Ra-226 target and may be shipped with the Ac- 227 medical isotope or shipped separately.

(c) Inventories of radioactive materials shown are less than Type B quantities as defined in 10 CFR 71 Appendix A; however, for the purposes of this analysis, all shipments are assumed to be shipped in Type B shipping casks. 
HNF-1844, Rev. 0

Table 2. Radiological Source Term for Irradiated Target Activation Products used in the Analysis of Irradiated Target ${ }^{(a)}$

\begin{tabular}{|l|c|c|c|c|c|}
\hline \multirow{3}{*}{ Isotope } & \multicolumn{2}{|c|}{$\begin{array}{c}\text { Long irradiation vehicle or target element } \\
\text { activation products selected for analysis }\end{array}$} & \multicolumn{2}{c|}{$\begin{array}{c}\text { 30 Long-Irradiation } \\
\text { Vehicles or Targets }\end{array}$} \\
\cline { 2 - 6 } & $\begin{array}{c}\text { Element } \\
\text { Ci/g }\end{array}$ & $\begin{array}{c}\text { Curies per } \\
\text { Element }\end{array}$ & $\begin{array}{c}\text { Curies of } \\
\text { Crud } \\
\text { Element }^{(\text {per }}\end{array}$ & $\begin{array}{c}\text { Curies per } \\
\text { 30 Elements }\end{array}$ & $\begin{array}{c}\text { Curies of } \\
\text { Crud per 30 } \\
\text { Elements }\end{array}$ \\
\hline C058 & $1.31 \mathrm{E}+00$ & $1.54 \mathrm{E}+04$ & $1.81 \mathrm{E}-05$ & $4.62 \mathrm{E}+05$ & $5.56 \mathrm{E}-03$ \\
\hline Co60 & $3.05 \mathrm{E}-03$ & $3.60 \mathrm{E}+01$ & $1.85 \mathrm{E}-04$ & $1.08 \mathrm{E}+03$ & $1.30 \mathrm{E}-05$ \\
\hline Mn54 & $1.27 \mathrm{E}-01$ & $1.50 \mathrm{E}+03$ & $4.33 \mathrm{E}-07$ & $4.51 \mathrm{E}+04$ & $5.42 \mathrm{E}-04$ \\
\hline Ta182 & $3.07 \mathrm{E}-02$ & $3.62 \mathrm{E}+02$ & $4.36 \mathrm{E}-06$ & $1.09 \mathrm{E}+04$ & $1.31 \mathrm{E}-04$ \\
\hline & Activation products not considered in analysis & \\
\hline H3 & Sc46 & Ni59 & Zr95 & Nb95 & Tc99 \\
\hline C14 & Cr51 & Ni63 & Nb92 & Nb95M & Ru103 \\
\hline P32 & Fe55 & Zn65 & Nb94 & Mo93 & W185 \\
\hline Ca45 & Fe59 & Y90 & & & \\
\hline
\end{tabular}

(a) Stainless steel cladding was assumed for this analysis.

(b) Selection of dominant activation products for analysis was based on a screening analysis performed by multiplying together the radionuclide inventories for each activation product and their respective inhalation dose conversion factors taken from EPA (1988). The four isotopes considered in the analysis represent over 99 percent of inhalation "risk."

(c) "Crud" is the activated corrosion products adhering to or deposited on the external surface of the irradiated targets. Quantities of crud per target were derived from crud characterization studies on pressurized water reactor (PWR) fuel assemblies (Adams 1990). 
HNF-1844, Rev. 0

Table 3. Radiological Source Terms for Liquid and Solid Waste Shipments ${ }^{(a)}$

\begin{tabular}{|l|c|c|}
\hline \multicolumn{1}{|c|}{ Isotope } & $\begin{array}{c}\text { Liquid Waste } \\
\text { (Ci/Shipment) }\end{array}$ & $\begin{array}{c}\text { Solid Waste } \\
\text { (Ci/Shipment) }\end{array}$ \\
\hline Ac228 & $6.79 \mathrm{E}-03$ & $3.69 \mathrm{E}-06$ \\
\hline Co58 ${ }^{(b)}$ & $2.35 \mathrm{E}-03$ & $1.49 \mathrm{E}-05$ \\
\hline Co60 ${ }^{(b)}$ & $2.35 \mathrm{E}-02$ & $1.49 \mathrm{E}-04$ \\
\hline Eu152 & $5.00 \mathrm{E}+02$ & $2.72 \mathrm{E}-01$ \\
\hline Eu154 & $2.63 \mathrm{E}+03$ & $1.43 \mathrm{E}+00$ \\
\hline Eu155 & $9.21 \mathrm{E}+02$ & $5.01 \mathrm{E}-01$ \\
\hline Eu156 & $1.24 \mathrm{E}+04$ & $6.74 \mathrm{E}+00$ \\
\hline I129 & $1.62 \mathrm{E}-05$ & $8.81 \mathrm{E}-09$ \\
\hline Mn54 ${ }^{(b)}$ & $5.49 \mathrm{E}-05$ & $3.49 \mathrm{E}-07$ \\
\hline Os191 & $4.92 \mathrm{E}+04$ & $2.68 \mathrm{E}+01$ \\
\hline Os193 & $2.26 \mathrm{E}+04$ & $1.23 \mathrm{E}+01$ \\
\hline Sr90 & $2.21 \mathrm{E}-02$ & $1.20 \mathrm{E}-05$ \\
\hline Ta182 & $5.53 \mathrm{E}-04$ & $3.51 \mathrm{E}-06$ \\
\hline
\end{tabular}

(a) Selection of dominant activation products for analysis was based on a screening analysis performed by multiplying together the radionuclide inventories for each activation product and their respective inhalation dose conversion factors taken from EPA (1988). These isotopes listed in this table represent over 99 percent of inhalation "risk."

(b) Source terms for these isotopes are derived from information provided in Table 2. 
HNF-1844, Rev. 0

\subsection{TRANSPORTATION SYSTEM DESCRIPTIONS}

This section provides a description of representative shipping containers that will be used to transport the enriched unirradiated target materials, unirradiated and irradiated targets, separated isotopes, and solid and liquid wastes. This section also provides a description of the truck and air transportation routes.

\subsection{Description of Shipping Containers}

The following sections provide descriptions of the representative shipping casks for irradiated target shipments, and separated isotopes shipments (both overland and air). There are no special packaging requirements associated with the transport of the target materials or unirradiated targets. It is assumed that all truck shipments of radioactive materials will comply with the appropriate packaging requirements contained in 10 CFR 71 (Type B container) and 49 CFR 173 (Type A container). All air shipments will comply with the requirements contained in 49 CFR 175 . It is assumed the irradiated targets would be placed in a "shielded pig" and then placed into a T-2 shipping cask, rapid retrieval targets or first placed directly into a T-2 shipping cask (long irradiation vehicle or target). The isotope products would be shipped in a CI-20WC-2A cask and the solid and liquid wastes would be shipped in a 55 gallon steel drum and bowling ball cask, respectively. A summary of the shipping cask dimensions and construction materials is provided in Table 4.

3.1.1 Irradiated Target Assemblies. Although there are two different target vehicles, the long irradiated target vehicle (up to $1 \mathrm{~m}$ in length) and the rapid retrieval target vehicle (up to $20 \mathrm{~cm}$ in length), both irradiation vehicles will be shipped from the FFTF to 325 Building using the T-2 shipping cask. The elements or pins from the long irradiation target vehicles will be inserted directly into the shipping cask, whereas the rapid retrieval targets will be inserted into a smaller package "shielded pig", which will be inserted into the shipping cask. For the purposes of this analysis, it is assumed that the elements or pins from one assembly (i.e., carrying a single target isotope and its associated impurities) will be shipped at a time.

The following subsections discuss the proposed long irradiated target vehicle shipping cask and the rapid retrieval target package.

3.1.1.1 Long Irradiated Target Vehicle Shipping Cask. The long-length irradiated target shipping cask will be used for transporting irradiated targets. A typical example for this type of casks is the T-2 shipping cask (shown in Figure 2.). This cask has been used on the Hanford Site in the past and is certified to carry sodium-bonded metal fuel pins (NRC 1988). The T-2 meets the requirements for a Type B shipping package. 
HNF-1844, Rev. 0

The T-2 cask is $116 \mathrm{in.}$ long with a $100 \mathrm{in}$. long by $6 \mathrm{in}$. I.D. liner made of schedule 40 stainless steel pipe. The outside shell of the cask is made in three sections. The center section is a 24 in. O.D. schedule 40 carbon steel pipe. Each end section is made of 16 in. O.D. schedule 40 carbon steel pipe. The space between the liner and shell is filled with lead for shielding. At the top, there is a 7-5/8 in. I.D. opening which is closed by an 8 in. thick stainless steel shield plug. Figure 2 shows the cross section of a T-2 cask with dimensions. The cask is enclosed in a steel shipping case during transport. 
HNF-1844, Rev. 0

Table 4. Shipping Cask Dimensions and Construction Materials, from Inner Cavity to Outer Wall (in inches)

\begin{tabular}{|c|c|c|c|c|c|c|c|c|c|c|c|c|c|c|c|}
\hline \multirow{2}{*}{$\begin{array}{l}\text { Shipping } \\
\text { Cask }\end{array}$} & \multirow{2}{*}{\begin{tabular}{|l|}
$\begin{array}{l}\text { Inner } \\
\text { cavity }\end{array}$ \\
Radius
\end{tabular}} & \multicolumn{2}{|c|}{$1^{\text {st }}$ Layer } & \multicolumn{2}{|c|}{$2^{\text {nd }}$ Layer } & \multicolumn{2}{|c|}{$3^{\text {rd }}$ Layer } & \multicolumn{2}{|c|}{$4^{\text {th }}$ Layer } & \multicolumn{2}{|c|}{$5^{\text {th }}$ Layer } & \multicolumn{2}{|c|}{$6^{\text {th }}$ Layer } & \multicolumn{2}{|c|}{$7^{\text {th }}$ Layer } \\
\hline & & Thick. & Matl. & Thick. & Matl. & Thick. & Matl. & Thick. & Matl. & Thick. & Matl. & Thick. & Matl. & Thick. & Matl. \\
\hline T-2 (center) & 3.0 & 0.3 & SStl & 8.0 & Lead & 0.7 & Stl & \multicolumn{8}{|c|}{ No additional shielding provided } \\
\hline Shielded Pig & 2.0 & 0.25 & SStl & 1.5 & Lead & 0.25 & SStI & \multicolumn{8}{|c|}{ No additional shielding provided } \\
\hline $\begin{array}{l}\text { 200-gallon } \\
\text { Bowling Ball } \\
\text { Cask }\end{array}$ & 22.25 & 0.5 & Stl & 8.0 & Lead & 0.5 & Stl & \multicolumn{8}{|c|}{ No additional shielding provided } \\
\hline $\begin{array}{l}\text { 55- gallon } \\
\text { drum }\end{array}$ & 11.25 & 0.05 & Stl & \multicolumn{12}{|c|}{ No additional shielding provided } \\
\hline
\end{tabular}

Stl- Steel unspecified

SStl- Stainless steel

DU- Depleted uranium 
HNF-1844, Rev. 0
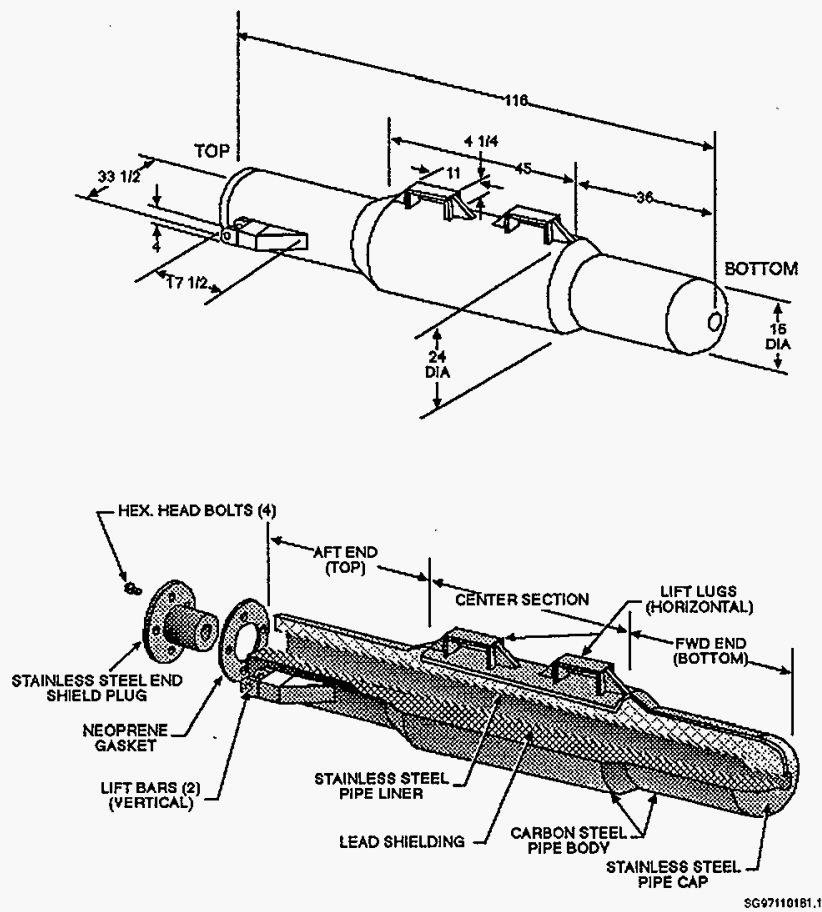

Figure 2. T-2 Shipping Cask: Long-length Irradiated Target. 
3.1.1.2 Rapid Retrieval Target Vehicle Package. The rapid retrieval targets will be packaged in a container and inserted in the T-2 shipping cask for transport to the 325 Building from FFTF. A 'shielded pig' or sample pig will be used for packaging the rapid retrieval targets. For the purposes of this analysis, the proposed 'shielded pig' is assumed to be 48 in. tall by 6 in. in diameter. Based on existing sample pig design information, the 'shielded pig' inner and outer walls will be constructed with schedule 40 carbon steel pipe. Lead shielding will be provided between the inner and outer carbon steel pipes in a "sandwich" configuration. The T-2 will be equipped with spacers to prevent the movement of the sample pig within the T-2 cask cavity. Smaller (i.e., shorter) shielded pigs have been approved for use on the Hanford Site in the past. It is anticipated that the longer shielded pig proposed for the transport of the rapid retrieval targets will also be approved for use on the Hanford Site.

3.1.2 Separated Isotope. The CI-20WC-2 or CI-20WC-2A container can be used for shipping the separated isotopes from PNNL to the pharmaceutical distributor. Following target processing, the separated isotopes, either as liquids, gasses or solids, will be placed in glass vials and inserted into the CI-20WC-2 or CI-20WC-2A. These casks have been certified for both overland and air shipments (NRC 1988). For this analysis, it is assumed the CI-20WC-2A will be used for the separated isotope shipments. The CI-20WC-2A is certified as a Type B shipping package.

The CI-20WC-2A container, shown in Figure 3, consists of an outer steel jacket, 24.25 in high by 18 in. in diameter and an inner depleted uranium shipping cask, 9 in. high by 4.5 in. in diameter and 1.8 in. thick. Between the outer steel jacket and the depleted uranium cask is a wooden impact limiter 5.5 in. thick on the sides, top and bottom. The inner and outer walls of the depleted uranium cask are constructed of schedule 40 carbon steel pipe with a gasketed and bolted flange closure. The inner cavity of the depleted uranium cask, which is designed to accept a $2 \mathrm{R}$ shipping container, is 6 in. high and $3.1 \mathrm{in}$. in diameter.

The 2R shipping container is a $2.73 \mathrm{in.}$ OD X $5.56 \mathrm{in.}$ long stainless steel, gasketed and threaded container. Spacers will be placed within the 2R shipping container to limit the movement of the glass vial containing the separated isotope.

\subsubsection{Solid and Liquid Waste.}

Solid wastes will be shipped from the PNNL facility to Hanford's Solid Waste Disposal Facility in the 200 West Area using a 55-gallon drum. A Bowling Ball Cask will be used to transfer liquid wastes generated by the medical isotope separation process at the PNNL 325 Building to the Hanford Site tank farms located in the 200 East Area. These shipping packages have been approved for use on the Hanford Site in the past. These shipping containers are discussed in the following. 
HNF-1844, Rev. 0

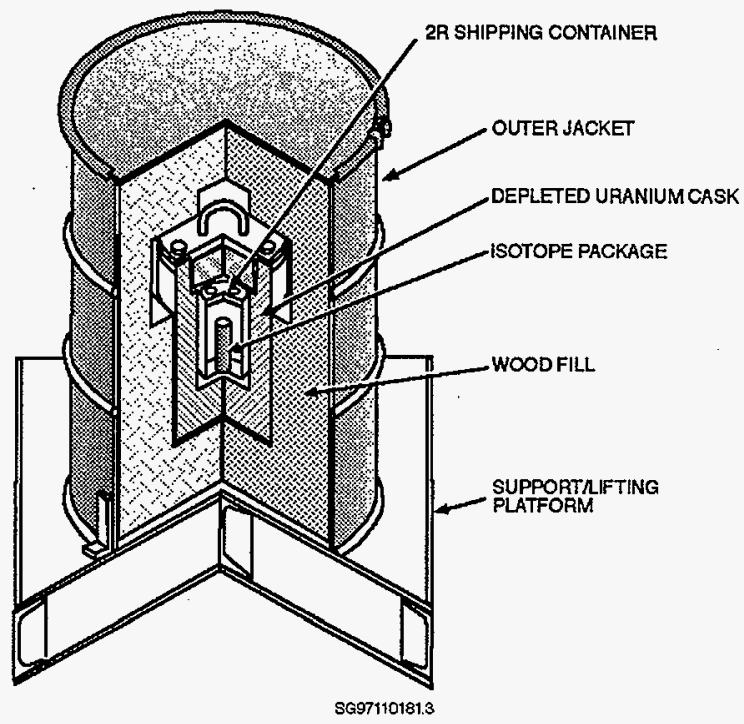

Figure 3. CI-20WC-2A Shipping Casks: Separated Isotopes 
3.1.3.1 55-Galion Drums. The 55 gallon drums are certified for onsite shipments of Type A and Type B quantities of solid wastes on the Hanford Site. A 55 gallon drum has a maximum capacity of approximately $9 \mathrm{cu} \mathrm{ft}$ of low-level solid waste; however, if necessary to reduce external dose rates, shielding can be added thus reducing the capacity.

If required by regulations to reduce the external doses, the 55-gal drum can be placed into an overpack. The N-55 Overpack (certified as a Type B package) is a circular cylinder that is $32 \mathrm{in}$. in diameter by $48 \mathrm{in}$. in height. The cavity has a diameter of $24 \mathrm{in}$. and a height of $34 \mathrm{1} / \mathrm{i}$ in. constructed of a 20 -gauge galvanized steel shell filled with rigid polyurethane foam.

3.1.3.2 Bowling Ball Liquid Waste Casks. Bowling ball casks are used to store and transfer radioactive liquid waste. A 200-gal. capacity bowling ball cask is shown in Figure 4. The containment body consists of two concentric spherical shells positioned on top of a support frame. The inner shell has a diameter of $44.5 \mathrm{in}$. I.D. The outer shell has a outside diameter of 62.5 in. Both shells have a thickness of $1 / 2$ in. The lead shielding between the shell is about 8 in. thick. The top of the cask is shielded by a top lead plug.

\subsection{ROUTE DESCRIPTIONS}

The bounding transportation routes assumed for this analysis are shown in Table 5 . The information shown in Table 5 includes the shipping distances and population density data. These data were developed using the HIGHWAY (Johnson et al. 1993) computer code for offsite truck shipments. Onsite route descriptions were estimated using site maps. The population density data for on-site shipments were developed using site maps and uses suburban population densities to represent occupied facilities and rural population densities for all other areas adjacent to the transport route. These data are summarized in Table 5 for each transport segment described in Section 2. 
HNF-1844, Rev. 0

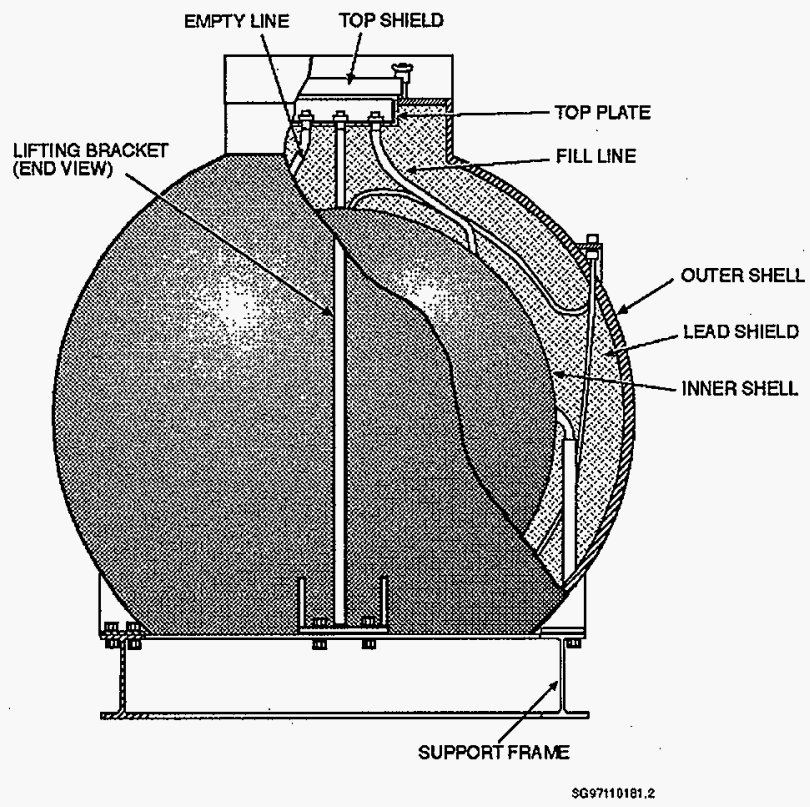

Figure 4. 200 Gallon Bowling Ball Cask. 
HNF-1844, Rev. 0

Table 5. Summary of Transportation Routing Information

\begin{tabular}{|c|c|c|c|c|c|c|c|c|}
\hline \multirow{2}{*}{\multicolumn{2}{|c|}{$\frac{\text { Option/Material Transported }}{\text { Transportation Route }}$}} & \multicolumn{2}{|c|}{$\begin{array}{l}\text { Shipment Description } \\
\text { (km one-way) }\end{array}$} & \multicolumn{5}{|c|}{ Population Densities (people/ $\left./ \mathrm{km}^{2}\right)^{(\mathrm{n})}$} \\
\hline & & \multirow[t]{2}{*}{ Onsite } & \multirow[t]{2}{*}{ Offsite } & \multicolumn{2}{|c|}{ Onsite } & \multicolumn{3}{|c|}{ Onsite } \\
\hline Origin & Destination & & & Rural & Suburban & Rural & Suburban & Urban \\
\hline \multicolumn{9}{|c|}{ Unirradiated Target Material, not including Ra-226 Target } \\
\hline ORNL & 300 Area & NA & 3834 & \multicolumn{2}{|c|}{ Not Applicable } & $\begin{array}{l}6.4 \\
(3,381)\end{array}$ & $\begin{array}{l}342.2 \\
(411)\end{array}$ & $\begin{array}{l}2,087.6 \\
(42)\end{array}$ \\
\hline \multicolumn{9}{|c|}{ Unirradiated Targets, including Ra-226 Target } \\
\hline 300 Area & FFTF & 14 & NA & $\begin{array}{l}2.4 \\
(10) \\
\end{array}$ & $\begin{array}{l}89.8 \\
(4)\end{array}$ & \multicolumn{3}{|c|}{ Not Applicable } \\
\hline \multicolumn{9}{|c|}{ Irradiated Targets } \\
\hline FFTF & 325 Building & 14 & NA & $\begin{array}{l}2.4 \\
(10)\end{array}$ & $\begin{array}{l}89.8 \\
(4)\end{array}$ & \multicolumn{3}{|c|}{ Not Applicable } \\
\hline \multicolumn{9}{|c|}{ Separated Medical Isotope } \\
\hline 325 Building & $\begin{array}{l}\text { Pasco/Kennewick/ } \\
\text { Richland Aipport }\end{array}$ & NA & 32 & Not Ap & & $\begin{array}{l}6.4 \\
(22)\end{array}$ & $\begin{array}{l}342.2 \\
(9)\end{array}$ & $\begin{array}{l}2,087.6 \\
\text { (1) }\end{array}$ \\
\hline $\begin{array}{l}\text { Pasco/KennewickJ } \\
\text { Richland Airport }\end{array}$ & Salt Lake City Airport & NA & 521 & \multicolumn{5}{|c|}{ Not Applicable } \\
\hline Salt Lake City Airport & Boston, Ma Airport & NA & 2105 & \multicolumn{5}{|c|}{ Not Applicable } \\
\hline Boston, $\mathrm{Ma}$ & Dupont-Merck & NA & 35 & \multicolumn{2}{|c|}{ Not Applicable } & $\begin{array}{l}14.5 \\
(5)\end{array}$ & $\begin{array}{l}478.9 \\
(18) \\
\end{array}$ & $\begin{array}{l}2,563.5 \\
(12)\end{array}$ \\
\hline Salt Lake City Aiport & Chicago, Il Airport & NA & 1257 & \multicolumn{5}{|c|}{ Not Applicable } \\
\hline Chicago, Il Airport & Amersham Mediphysics & $\mathrm{NA}$ & 32 & \multicolumn{2}{|c|}{ Not Applicable } & $\begin{array}{l}7.8 \\
(7)\end{array}$ & $\begin{array}{l}670.3 \\
(8)\end{array}$ & $\begin{array}{l}2,829.0 \\
(17)\end{array}$ \\
\hline
\end{tabular}


HNF-1844, Rev. 0

Table 5. Summary of Transportation Routing Information

\begin{tabular}{|c|c|c|c|c|c|c|c|c|}
\hline \multirow{2}{*}{\multicolumn{2}{|c|}{$\begin{array}{c}\text { Option/Material Transported } \\
\text { Transportation Route }\end{array}$}} & \multicolumn{2}{|c|}{$\begin{array}{l}\text { Shipment Description } \\
\text { (km one-way) }\end{array}$} & \multicolumn{5}{|c|}{ Population Densities (people//km²) } \\
\hline & & \multirow[t]{2}{*}{ Onsite } & \multirow[t]{2}{*}{ Offsite } & \multicolumn{2}{|c|}{ Onsite } & \multicolumn{3}{|c|}{ Offsite } \\
\hline Origin & Destination & & & Rural & Suburban & Rural & Suburban & Urban \\
\hline $\begin{array}{l}\text { Salt Lake City, Ut } \\
\text { Airport }\end{array}$ & St. Louis, Mo Airport & NA & 1,156 & \multicolumn{5}{|c|}{ Not Applicable } \\
\hline St. Louis, Mo Airport & Mallinckrodt & NA & 13 & Not $A_{t}$ & & $\begin{array}{l}2.3 \\
(\mathbf{1}) \\
\end{array}$ & $\begin{array}{l}778.1 \\
(6) \\
\end{array}$ & $\begin{array}{l}2,611.2 \\
(6)\end{array}$ \\
\hline \multicolumn{9}{|c|}{ Liquid and Solid Waste Shipments from PNNL to 200 East and West Areas } \\
\hline 325 Building & $\begin{array}{l}\text { Liquid Waste to } 200 \\
\text { East Area Tank Farms }\end{array}$ & 35 & NA & $\begin{array}{l}2.4 \\
(34)\end{array}$ & $\begin{array}{l}89.8 \\
(1)\end{array}$ & \multicolumn{3}{|c|}{ Not Applicable } \\
\hline 325 Building & $\begin{array}{l}\text { Solid Waste to } 200 \\
\text { West Area Solid Waste } \\
\text { Facility }\end{array}$ & 43 & NA & $\begin{array}{l}2.4 \\
\text { (39) }\end{array}$ & $\begin{array}{l}89.8 \\
(4)\end{array}$ & \multicolumn{3}{|c|}{ Not Applicable } \\
\hline
\end{tabular}

(a) Values shown in parenthesis are the total $\mathrm{km}$ traveled within the population zone. 


\subsection{INPUT PARAMETERS FOR TRANSPORTATION IMPACT ANALYSIS}

This section provides the input parameters used to perform the transportation impact analysis. The RADTRAN 4 computer code (see Section 1.1.) is used to calculate routine and accident radiological impacts. Hand calculations are used to calculate non-radiological routine and accident impacts. The input parameters, for both radiological and nonradiological routine and accident impacts, required to perform the analysis include distance traveled, persons exposed during the shipment of the isotope, including occupants of vehicles on the roadway, persons adjacent to the transport route, and persons within the vehicle (airplane or truck), and a description of the package, including dimensions, external exposure rates and failure mechanisms.

A key input parameter in the RADTRAN calculations is the radiation dose rate emitted from the loaded shipping containers. In RADTRAN, this parameter is the TI value. The TI value for the shipments are defined as the radiation dose rate at $1 \mathrm{~m}$ from the external surface of the shipping containers. TI values for the irradiated target and separated isotope product shipments were calculated using MICROSHIELD Version 5.01 (Grove Engineering 1996). The other shipments were assumed to emit radiation levels equivalent to regulatory limits, which equates to a TI value of about $13.7 \mathrm{mrem} / \mathrm{hr}$ (RADTRAN 4 internally checks the input TI value and resets to a lower dose rate if it is determined that the TI value would exceed regulatory maximum levels).

MICROSHIELD calculates the direct line-of-sight radiation dose rate emitted from a radioactive source. A cylindrical source with cylindrical side shields was the geometry selected to model the shipments. Figure 5 illustrates the CI-20WC-2A shipping cask geometry and Figure 6 illustrates the T-2 shipping cask geometry used in the MICROSHIELD calculations. The dose point coordinates used in the calculations are located $100 \mathrm{~m}$ from the external surfaces of the casks ( $\mathrm{X}$ coordinate) and at the mid-point of the source ( $\mathrm{Y}$ coordinate).

The radioactive materials were assumed to be uniformly distributed within the shipping container's internal cavity. The source was conservatively assumed to be represented by air. Source inventories were provided in Section 2. Shielding thicknesses and materials provided by the shipping casks and internal containers were taken from Section 3.1. Note that the CI20WC-2 and CI-20WC-2A containers are provided with a $14 \mathrm{~cm}(5.5 \mathrm{in})$ thick wooden layer. Since the properties of wood are not in the MICROSHIELD materials library, it was assumed to be modeled as water with a density of $0.5 \mathrm{~g} / \mathrm{cm}^{3}$. This density is near the lower end of the range of wood densities and should result in conservatively-high radiation dose rates. Shielding properties of air, lead, uranium, and iron (for stainless steel) were taken from the materials library provided by MICROSHIELD.

The results of the MICROSHIELD calculations are presented in Table 6. 


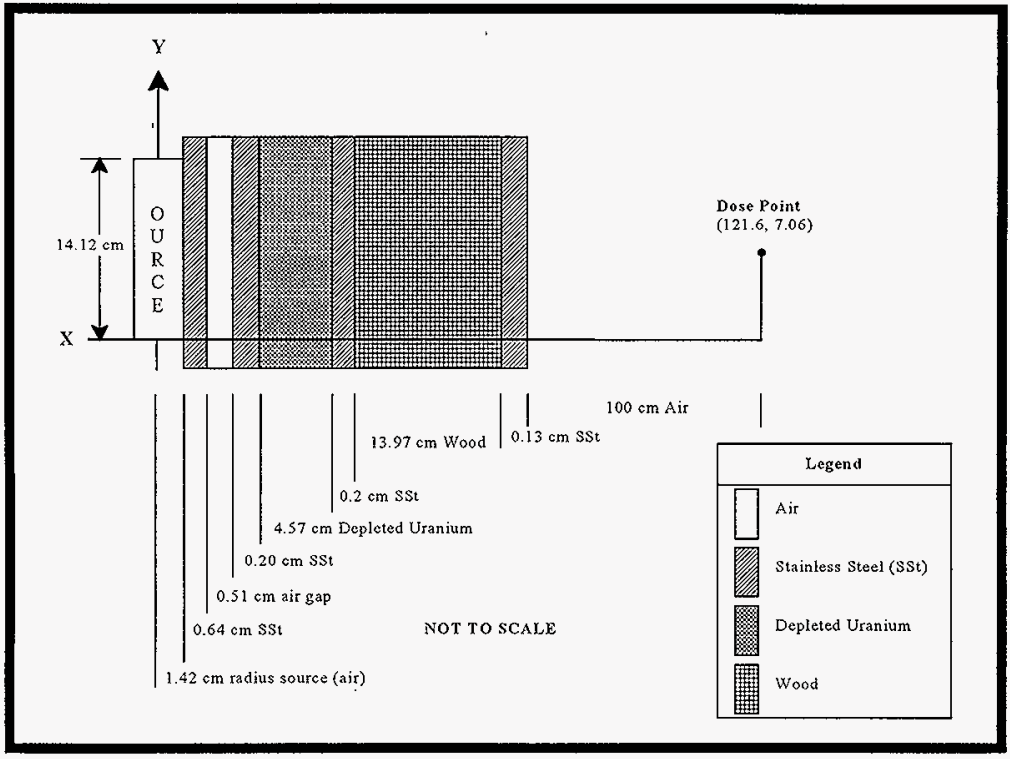

Figure 5. Geometry of Cl-20WC-2A Shipping Cask 
HNF-1844, ReV. 0

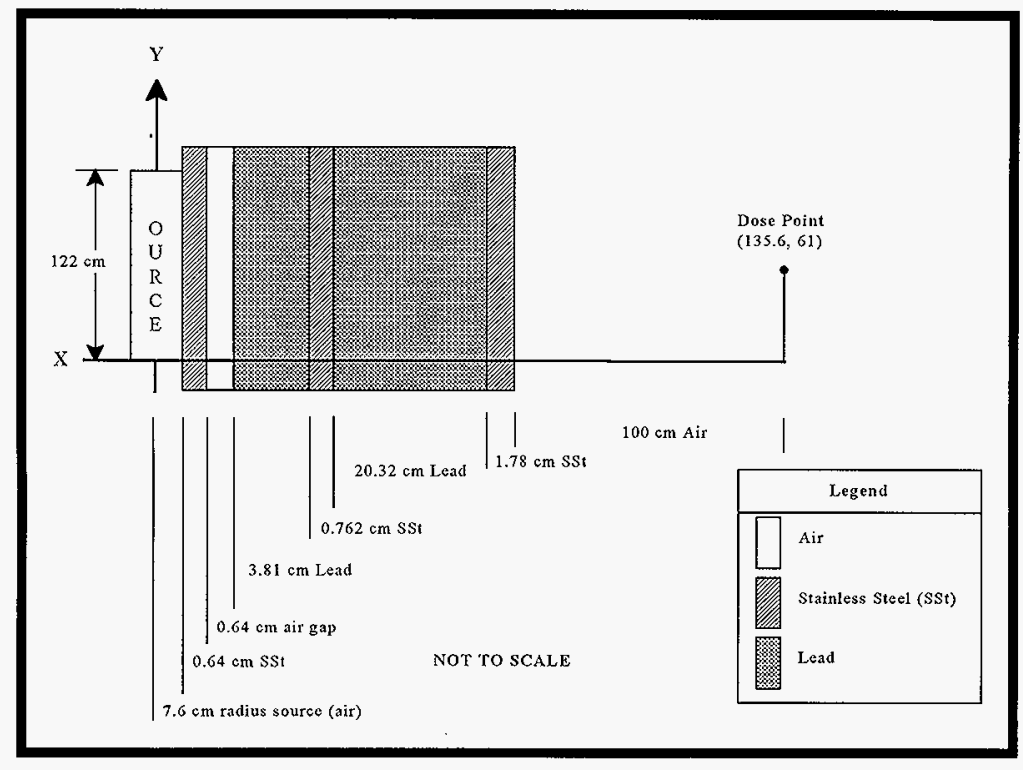

Figure 6. Geometry of T-2 Shipping Cask 
HNF-1844, Rev. 0

Table 6. Calculated TI's for Irradiated Target and Medical Isotope Shipments

\begin{tabular}{|c|c|c|c|c|c|}
\hline \multirow[t]{2}{*}{ Isotope } & \multicolumn{2}{|c|}{ Calculated TI (mrem/hr) } & \multirow[t]{2}{*}{ Isotope } & \multicolumn{2}{|c|}{ Calculated TI (mrem/hr) } \\
\hline & $\begin{array}{c}\text { Irradiated } \\
\text { Targets }\end{array}$ & $\begin{array}{l}\text { Medical } \\
\text { Isotopes }\end{array}$ & & $\begin{array}{c}\text { Irradiated } \\
\text { Targets }\end{array}$ & $\begin{array}{l}\text { Medical } \\
\text { Isotopes }\end{array}$ \\
\hline Ac-227 & $1.65 \mathrm{E}-01$ & $1.19 \mathrm{E}-07$ & Pd-103 & $2.54 \mathrm{E}-01$ & $1.35 \mathrm{E}-08$ \\
\hline $\mathrm{Au}-198$ & $1.65 \mathrm{E}-01$ & $2.24 \mathrm{E}+00$ & Pt-195m & $1.65 \mathrm{E}-01$ & $3.40 \mathrm{E}-05$ \\
\hline Cd-109 & $1.93 \mathrm{E}-01$ & $3.70 \mathrm{E}-20$ & $\operatorname{Re}-186$ & $1.65 \mathrm{E}-01$ & $1.30 \mathrm{E}+01^{(2)}$ \\
\hline $\mathrm{Cu}-64$ & $2.54 \mathrm{E}-01$ & $1.23 \mathrm{E}+00$ & Sc-47 & $2.54 \mathrm{E}-01$ & $9.33 \mathrm{E}-14$ \\
\hline $\mathrm{Cu}-67$ & $2.54 \mathrm{E}-01$ & $9.54 \mathrm{E}-09$ & $\mathrm{Se}-75$ & $1.65 \mathrm{E}-01$ & $3.27 \mathrm{E}-02$ \\
\hline Gd-153 & $1.30 \mathrm{E}+01^{(a)}$ & $2.55 \mathrm{E}-17$ & Sm-145 & $1.65 \mathrm{E}-01$ & $6.61 \mathrm{E}-02$ \\
\hline Ho-166 & $1.66 \mathrm{E}-01$ & $7.79 \mathrm{E}+00$ & $\mathrm{Sm}-153$ & $1.65 \mathrm{E}-01$ & $1.01 \mathrm{E}-01$ \\
\hline $\mathrm{I}-125$ & $1.71 \mathrm{E}-01$ & $4.21 \mathrm{E}-19$ & Sn- $117 m$ & $2.54 \mathrm{E}-01$ & $6.13 \mathrm{E}-18$ \\
\hline I-131 & $1.74 \mathrm{E}-01$ & $5.50 \mathrm{E}+00$ & $\mathrm{Sr}-85$ & $2.54 \mathrm{E}-01$ & $3.64 \mathrm{E}+00$ \\
\hline Ir-192 & $1.71 \mathrm{E}-01$ & $1.30 \mathrm{E}+0 \mathrm{I}^{(2)}$ & Sr-89 & $2.54 \mathrm{E}-01$ & $1.02 \mathrm{E}-01$ \\
\hline Lu-177 & $1.65 \mathrm{E}-01$ & $1.94 \mathrm{E}-13$ & Thorium & See Ac-227 & $1.19 \mathrm{E}-07$ \\
\hline Mo-99 & $1.68 \mathrm{E}-01$ & $1.30 \mathrm{E}+01^{(\mathrm{a})}$ & W-188 & $1.74 \mathrm{E}-01$ & $1.30 \mathrm{E}+01^{(\mathrm{a})}$ \\
\hline Os- $194^{(b)}$ & $1.65 \mathrm{E}-01$ & $1.30 \mathrm{E}+01$ & $\mathrm{Xe}-127$ & $2.54 \mathrm{E}-01$ & $1.14 \mathrm{E}-03$ \\
\hline $\mathrm{P}-32^{(\mathrm{c})}$ & $2.54 \mathrm{E}-01$ & $0.00 \mathrm{E}+00$ & $X-91$ & $2.54 \mathrm{E}-01$ & $2.26 \mathrm{E}+00$ \\
\hline $\mathrm{P}-33^{\text {(c) }}$ & $2.54 \mathrm{E}-01$ & $0.00 \mathrm{E}+00$ & & & \\
\hline
\end{tabular}

(a) Shielding calculations indicate these shipments might exceed regulatory dose limits using the standard shielding configuration. A different shipping configuration (i.e., additional shielding or different shipping cask) was assumed to allow shipments up to the inventories shown in Table 1 . A TI of $13 \mathrm{mrem} / \mathrm{hr}$. would result in a dose rate slightly below the regulatory limit.

(b) Os-194 is not in the MICROSHIELD source database and was not included in routine radiation dose calcuiations of separated isotopes. Irradiated target TI is based on the presence of activated hardware or target cladding.

(c) P-32 and P-33 decay does not emit gamma radiation. 
Section 4.1 provides the input parameters for the truck shipments and Section 4.2 provides the input parameters for the air transport shipments.

\subsection{TRUCK TRANSPORT INPUT PARAMETERS}

The following subsections provide the input parameters used to calculate radiological and non-radiological impacts from routine and accident truck transport conditions.

4.1.1 Radiological Impacts from Routine Transportation. Routine radiological impacts are calculated using the RADTRAN 4 computer code. RADTRAN 4 input parameters for calculating routine truck crew and population doses include route information (i.e., shipping distances and fractions of travel in rural, suburban, and urban population zones), shipping cask external exposure rate, and the number of individuals potentially exposed to the shipment. These data are presented in Tables 5 and 7.

The calculation of in-transit radiological impacts requires the number of individuals potentially exposed to the shipment, including the truck crew and the public. These data are shown in Table 5 and include the population densities in rural, suburban and urban population zones, fractions of travel within each population zone, the number of individuals and average exposure distances at truck stops, and the number of individuals in a truck crew and their exposure distance, (i.e., distance from the shipping cask to the truck crew). 
HNF-1844, Rev. 0

Table 7. RADTRAN Input Parameters

\begin{tabular}{|c|c|c|c|c|}
\hline Input parameter & $\begin{array}{c}\text { Unirradiated } \\
\text { Target } \\
\text { Material }\end{array}$ & $\begin{array}{l}\text { Irradiated } \\
\text { Target }\end{array}$ & $\begin{array}{l}\text { Product } \\
\text { Isotope }\end{array}$ & $\begin{array}{l}\text { Liquid and } \\
\text { Solid Waste }\end{array}$ \\
\hline \multicolumn{5}{|c|}{ Routing Description (see also Table 5) } \\
\hline Velocity in Rural Population Zone $(\mathrm{km} / \mathrm{h})^{(\mathrm{s})}$ & 88.6 & 88.6 & 88.6 & 88.6 \\
\hline Velocity in Suburban Population Zone $(\mathrm{km} / \mathrm{h})^{(\mathrm{n})}$ & 40.3 & 40.3 & 40.3 & 40.3 \\
\hline Velocity in Urban Population Zone $(\mathrm{km} / \mathrm{h})^{(1)}$ & 24.2 & 24.2 & 24.2 & NA \\
\hline $\begin{array}{l}\text { Percentage of Travel Distance in Rural Population Zone - } \\
\text { Onsite }\end{array}$ & $70(c)$ & 70 & 0 & 90 \\
\hline $\begin{array}{l}\text { Percentage of Travel Distance in Suburban Population Zone - } \\
\text { Onsite }\end{array}$ & $30(c)$ & 30 & 0 & 10 \\
\hline $\begin{array}{l}\text { Percentage of Travel Distance in Rural Population Zone - } \\
\text { Offsite }{ }^{(\phi)}\end{array}$ & 88 & 0 & $\begin{array}{c}1-69 \\
2-14 \\
3-22 \\
4-8\end{array}$ & 0 \\
\hline $\begin{array}{l}\text { Percentage of Travel Distance in Suburban Population Zone - } \\
\text { Offsite } \\
\end{array}$ & 11 & 0 & $\begin{array}{l}1-28 \\
2-52 \\
3-25 \\
4-46 \\
\end{array}$ & 0 \\
\hline $\begin{array}{l}\text { Percentage of Travel Distance in Urban Population Zone - } \\
\text { Offsite }^{(d)}\end{array}$ & 1 & 0 & $\begin{array}{c}1-3 \\
2-34 \\
3-53 \\
4-46\end{array}$ & 0 \\
\hline Number of Truck Crewmen & 2 & 2 & 2 & 2 \\
\hline Distance from Source to Crew (m) & 10.0 & 10.0 & 10.0 & 10.0 \\
\hline Stop Time per $\mathrm{km}(\mathrm{h} / \mathrm{km})^{(\mathrm{b})}$ & 0.011 & 0 & 0 & 0 \\
\hline Persons Exposed While Stopped ${ }^{(b)}$ & 50 & NA & NA & NA \\
\hline Average Exposure Distance While Stopped $(\mathrm{m})^{(\mathrm{k})}$ & 20.0 & NA & NA & NA \\
\hline Number of People per Vehicle on Link $k^{(b)}$ & 2 & 2 & 2 & 2 \\
\hline \multicolumn{5}{|c|}{ Shipping Cask Description } \\
\hline Dose rate $1 \mathrm{~m}$ from Vehicle/Package $(\mathrm{mrem} / \mathrm{h})$ & 0 & See Table 6 & See Table 6 & 13 \\
\hline Length of Package (m) & 1.0 & 1.0 & 0.8 & 1 \\
\hline
\end{tabular}

(a) Values shown are shipment-specific unless otherwise noted.

(b) Default values from RADTRAN (Neuhauser and Kanipe 1992 and Madsen et al. 1983).

(c) Percentages shown are for Ra-226 shipments from the 325 Building to FFTF

(d) 1 - Product isotope to Pasco/Kennewick/Richland Airport

2 - Product isotope from Boston Airport to Dupont-Merck

3 - Product isotope from Chicago Airport to Amersham Mediphysics

4 - Product isotope from St. Louis Airport to Mallinckrodt 
4.1.2 Radiological Impacts Due to Transportation Accidents. Radiological impacts from transportation accidents are calculated for the public as well as a maximum onsite and offsite individuals. The impacts to the public are presented in this section as integrated population risks (i.e., accident frequencies multiplied by consequences) for individual shipments and the stipulated number of annual shipments of each radioactive material. The impacts to the public and maximum individual are based on the radiological inventories shown in Tables 1 , 2 , and 3 .

Integrated population risk calculations are performed using the RADTRAN 4 computer code (Neuhauser and Kanipe 1992). The maximum individual doses due to a transportation accident are performed using GENII (Napier 1989). The following subsections provide the input parameters for the integrated population and maximum individual radiological impact analysis.

For this analysis, risk is defined as the product of the frequency of occurrence of an accident involving a shipment and the consequences of an accident. Consequences are expressed in terms of the radiological dose and latent cancer fatalities from a release of radioactive material from the shipping cask or the exposure of persons to radiation that could result from damaged package shielding. The frequency of an accident that involves radioactive materials is expressed in terms of the expected number of accidents per unit distance integrated over the total distance traveled. The response of the shipping cask to the accident environment and the probability of release or loss of shielding is related to the severity of the accident.

The frequencies of occurrence of transportation accidents that would release significant quantities of radioactive material are relatively small because the shipping casks are designed to withstand severe transportation accident conditions (i.e., the shipping casks for all the materials shipped in this analysis were assumed to meet the Type B packaging requirements specified in 10 CFR 71). Accidents on the road are difficult to totally eliminate. However, because the shipping casks are capable of withstanding certain accident environments, including severe mechanical and thermal stress, only a relatively small fraction of accidents involve conditions that are severe enough to result in a release of radioactive materials.

Should an accident involving a shipment occur, a release of radioactive material could occur only if the shipping cask and internal packaging were to fail. A failure would most likely be a small gap in a seal or small split in the containment vessel. For the radioactive material to reach the environment, it would have to pass through the split in the cask or through the failed seal. Materials released to the environment would be dispersed and diluted by weather action and a fraction would be deposited on the ground (i.e., drop out of the contaminated plume) in the surrounding region. Emergency response crews arriving on the scene would evacuate and secure the area to exclude bystanders from the accident scene. The released material would then be cleaned up using standard decontamination techniques, 
such as excavation and removal of contaminated soil. Monitoring of the area would be performed to locate contaminated areas and to guide cleanup crews in their choice of protective clothing and equipment (e.g., fresh-air equipment, filtered masks, etc.). Access to the area would be restricted by Federal and/or state radiation control agencies until it had been decontaminated to safe levels.

The RADTRAN 4 computer code was used to calculate the radiological risk of transportation accidents involving radioactive material shipments. The RADTRAN 4 methodology was summarized previously. For further details, refer to the discussions presented by RADTRAN III (Madsen et al. 1986) and RADTRAN 4: Volume 2 -- Technical Manual (Neuhauser and Kanipe 1995).

In addition to transportation route information discussed in Section 3.1.1, there are five major categories of input data needed to calculate potential accident transportation risk impacts using the RADTRAN 4 computer code. These are: 1) accident frequency, 2) release quantities, 3) atmospheric dispersion parameters, 4) population distribution parameters, and 5) human uptake and dosimetry models. Accident frequency and release quantities are discussed below. The remaining parameters have been discussed in previous sections.

\section{Accident Frequency}

The frequency of a severe accident is calculated by multiplying an overall accident rate (accidents per truck-kilometer) by the conditional probability that an accident would involve mechanical and/or thermal conditions that are severe enough to result in container failure and subsequent release of radioactive material. State-specific accident rates per kilometer of truck travel were taken from Saricks and Kvitek (1994) and combined with the shipping distances and travel fractions in rural suburban and urban population zones to calculate routespecific accident rates shown in Table 8. Hanford site accident rates per kilometer of truck travel were taken from Medical Isotope Production Project: Molybdenum-99 and Related Isotopes, Environmental Impact Statement (DOE 1996) (see Table 8).

For this analysis, six severity categories were defined, with category 1 as the least severe and the higher categories (2-6) representing increasingly severe conditions. The conditional probabilities of encountering accident conditions in each severity category were taken from a U.S. Nuclear Regulatory Commission (NRC) document (Filcher et al. 1987), which were developed based on reviews of accident records and statistics compiled by various State and Federal agencies. The conditional probability for a given severity category is defined as the fraction of accidents that would fall into that severity category if an accident were to occur. The conditional probabilities were determined using a binning process described in DOE (1994). The derivation of the accident rates and conditional probabilities used in this analysis is discussed below. 
As discussed above, six severity category levels were defined to model the response of the various shipments to accidents. Severity category 1 was defined as encompassing all accidents that are within the Type A Package envelope which would not be severe enough to result in failure of this type of shipping cask (i.e., accidents with zero release). Category 2 was defined to encompass the Type $B$ hypothetical test conditions. There would be no release from the Type B package if an accident in this severity category were to occur. The higher categories (3-6) were defined to include more severe accidents and thus may lead to a release of radioactive material. Table 9 presents the conditional probabilities of the various severity categories which were used in this analysis.

Table 8. Route Specific Accident Rates for Combination-Truck Shipments

\begin{tabular}{|c|c|c|c|}
\hline \multirow[t]{2}{*}{ Transport Route } & \multicolumn{3}{|c|}{$\begin{array}{l}\text { Combination-Truck Highway Accident Rate } \\
\text { (Accidents per Kilometer) }\end{array}$} \\
\hline & Rural & Suburban & Urban \\
\hline \multicolumn{4}{|c|}{ Unirradiated target materials, not including Ra-226 } \\
\hline ORNL to PNNL & $2.16 \mathrm{E}-07$ & $3.47 \mathrm{E}-07$ & $4.93 \mathrm{E}-07$ \\
\hline \multicolumn{4}{|c|}{ Unirradiated target materials, including Ra-226 } \\
\hline PNNL to FFTF ${ }^{(a)}$ & $8.86 \mathrm{E}-08$ & $8.86 \mathrm{E}-08$ & $8.86 \mathrm{E}-08$ \\
\hline \multicolumn{4}{|c|}{ Irradiated targets } \\
\hline FFTF to PNNL $^{(a)}$ & $8.86 \mathrm{E}-08$ & $8.86 \mathrm{E}-08$ & $8.86 \mathrm{E}-08$ \\
\hline \multicolumn{4}{|c|}{ Separated isotopes } \\
\hline PNNL to Pasco/Kennewick/Richland Airport & $2.50 \mathrm{E}-07$ & $2.06 \mathrm{E}-07$ & $1.61 \mathrm{E}-07$ \\
\hline Boston Airport to Du-Pont Merck & $6.47 \mathrm{E}-07$ & $3.95 \mathrm{E}-07$ & $1.42 \mathrm{E}-07$ \\
\hline Chicago Airport to Amersham Mediphysics & $1.76 \mathrm{E}-07$ & $5.26 \mathrm{E}-07$ & $8.75 \mathrm{E}-07$ \\
\hline St. Louis Airport to Mallinckrodt & $1.78 \mathrm{E}-07$ & $3.48 \mathrm{E}-07$ & $5.18 \mathrm{E}-07$ \\
\hline \multicolumn{4}{|c|}{ Liquid and solid waste } \\
\hline PNNL to the 200 East and West Areas ${ }^{(a)}$ & $8.86 \mathrm{E}-08$ & $8.86 \mathrm{E}-08$ & $8.86 \mathrm{E}-08$ \\
\hline
\end{tabular}

(a) Taken from DOE 1996 
HNF-1844, Rev. 0

Table 9. Accident Severity Categories and Conditional Probabilities ${ }^{(a)}$

\begin{tabular}{|l|c|c|c|c|c|c|}
\hline \multirow{2}{*}{ Mode/Truck } & \multicolumn{6}{|c|}{ Conditional Probability by Severity Category } \\
\cline { 2 - 8 } & $\mathbf{1}$ & $\mathbf{2}$ & $\mathbf{3}$ & $\mathbf{4}$ & $\mathbf{5}$ & $\mathbf{6}$ \\
\hline Rural & $4.62 \mathrm{E}-01$ & $3.02 \mathrm{E}-01$ & $1.76 \mathrm{E}-01$ & $4.03 \mathrm{E}-02$ & $1.88 \mathrm{E}-02$ & $6.84 \mathrm{E}-04$ \\
\hline Suburban & $4.36 \mathrm{E}-01$ & $2.85 \mathrm{E}-01$ & $2.21 \mathrm{E}-03$ & $5.06 \mathrm{E}-02$ & $8.38 \mathrm{E}-02$ & $7.31 \mathrm{E}-05$ \\
\hline Urban & $5.83 \mathrm{E}-01$ & $3.82 \mathrm{E}-01$ & $2.78 \mathrm{E}-02$ & $6.36 \mathrm{E}-03$ & $8.88 \mathrm{E}-04$ & $1.22 \mathrm{E}-05$ \\
\hline
\end{tabular}

(a) Taken from Madsen et al. 1986

\section{Release Fractions}

Release fractions (array RFRAC in RADTRAN 4) are used to determine the quantity of radioactive material released to the environment as a result of an accident. The quantity of material released is a function of the severity of the accident (i.e., thermal and mechanical conditions produced in the accident), the response of the shipping container to these conditions, and the physical and chemical properties of the material being shipped. The release fractions used in this analysis and the sources of the information are shown in Table 10 .

Table 10. Release Fractions Used for Assessment of Truck Accident Impacts $^{(a)}$

\begin{tabular}{|l|c|c|c|c|c|c|}
\hline \multicolumn{1}{|c|}{ Material } & \multicolumn{6}{|c|}{ Release Fraction by Severity Category } \\
\hline & $\mathbf{1}$ & $\mathbf{2}$ & $\mathbf{3}$ & $\mathbf{4}$ & $\mathbf{5}$ & $\mathbf{6}$ \\
\hline Targets ${ }^{(2)(\mathrm{b})}$ & & & & & & \\
Particles & $0.00 \mathrm{E}+00$ & $0.00 \mathrm{E}+00$ & $1.00 \mathrm{E}-09$ & $1.00 \mathrm{E}-08$ & $1.00 \mathrm{E}-08$ & $1.00 \mathrm{E}-07$ \\
\hline Separated & & & & & & \\
Isotopes & & & & & & \\
Gases ${ }^{(2)}$ & $0.00 \mathrm{E}+00$ & $0.00 \mathrm{E}+00$ & $1.00 \mathrm{E}+00$ & $1.00 \mathrm{E}+00$ & $1.00 \mathrm{E}+00$ & $1.00 \mathrm{E}+00$ \\
Liquids(c) & $0.00 \mathrm{E}+00$ & $0.00 \mathrm{E}+00$ & $5.00 \mathrm{E}-01^{\prime}$ & $1.00 \mathrm{E}+00$ & $1.00 \mathrm{E}+00$ & $1.00 \mathrm{E}+00$ \\
\hline Waste & & & & & & \\
Solid & $0.00 \mathrm{E}+00$ & $0.00 \mathrm{E}+00$ & $1.00 \mathrm{E}-09$ & $1.00 \mathrm{E}-08$ & $1.00 \mathrm{E}-08$ & $1.00 \mathrm{E}-07$ \\
Liquid(c) & $0.00 \mathrm{E}+00$ & $0.00 \mathrm{E}+00$ & $5.00 \mathrm{E}-01$ & $1.00 \mathrm{E}+00$ & $1.00 \mathrm{E}+00$ & $1.00 \mathrm{E}+00$ \\
\hline
\end{tabular}

(a) Taken from DOE 1996

(b) These release fractions were applied to truck shipments of irradiated targets from FFTF to the 325 Building and $\mathrm{Ra}-226$ shipments from 325 Building to FFTF

(c) Taken from Green 1995 
To determine radiological consequences, it is necessary to further characterize the material released. This additional characterization is required to determine the quantity of material aerosolized (i.e., particles small enough to be dispersed by wind) and respirable (i.e., particles small enough to be inhaled into the lungs). Table 11 provides the fraction aerosolized and respirable, based on the form of the material shipped.

\section{Table 11. Fraction of Shipped Material Aerosolized and} Respirable $^{(a)}$

\begin{tabular}{|l|c|c|}
\hline Material Shipped & Fraction Aerosolized & Fraction Respirable \\
\hline $\begin{array}{l}\text { Targets } \\
\text { Particles }\end{array}$ & 1.0 & 0.05 \\
\hline Separated Lsotopes & & \\
Gases & 1.0 & 0.05 \\
Liquids & 0.1 & 0.05 \\
\hline Waste & & \\
Solid & 1.0 & 0.05 \\
Liquid & 0.1 & 0.05 \\
\hline
\end{tabular}

(a) Default values from RADTRAN (Neuhauser and Kanipe 1992 and Madsen et al. 1983)

(b) These release fractions were applied to truck shipments of irradiated targets from FFTF to the 325 Building and Ra-226 shipments from the 325 Building to FFTF.

\section{Health Effects}

The output from The RADTRAN 4 computer analysis is presented in terms of the total effective dose equivalent (TEDE or dose) to the affected population. The TEDE was then used to express the consequences in terms of potential health effects or latent cancer fatalities (LCF). Recommendations of the International Commission on Radiological Protection (ICRP 1991) for low dose rate radiological exposures were used to convert the TEDE to LCF. The conversion factor applied to adult workers was $4 \times 10^{-4} \mathrm{LCF} / \mathrm{rem}$ TEDE, and that for the general population was $5 \times 10^{-4} \mathrm{LCF} / \mathrm{rem}$ TEDE. The general population was assumed to have a higher rate of cancer induction for a given radiation dose than healthy adult workers because of the presence of more sensitive individuals (e.g., children) in the general population. 


\subsubsection{Impacts to the Maximum Individual due to a Transportation Accident.}

Radiological doses for maximum-exposed individuals for the maximum credible transportation accident were calculated using GENII (Napier et al 1988). The maximally exposed onsite individual is assumed to be located $100 \mathrm{~m}$ from the point of release. The maximally exposed offsite individual, for conservatism, based on the proximity of the 300 Area and FFTF facilities to the Hanford Site boundary, was assumed to be located $580 \mathrm{~m}$ from the release (PNNL 1996). The radionuclide inventory used in this analysis is shown in Tables 1,2 , and 3 .

The maximum credible transportation accident would result in an accident with sufficient energy to breach the shipping cask, and fail the target cladding or isotope package, with an ensuing fire of sufficient heat and duration to release a fraction of the cladding material and/or all of the available isotope. However, due to Hanford Site transportation controls, such as, special driver training requirements, time of day and inclement weather restrictions, good roads, favorable terrain, and minimal flammable liquid transportation traffic, an accident of this magnitude is not considered credible. For this analysis, the maximum credible transportation accident was postulated to involve severe impact (mechanical damage) and an ensuing fire of short duration, that is less severe than the Type B packaging thermal stress conditions (less than $800^{\circ}$ fire for 30 minutes). The shipping cask and the target cladding are postulated to fail, thus exposing the irradiated isotope or target material to the environment. It was assumed that $10 \%$ of irradiated material is aerosolized and $5 \%$ of the aerosolized material is respirable.

Radiological impacts to the maximum offsite and onsite individual and the maximum individual were calculated using GENII (Napier et al. 1988). As discussed in Section 1.2 GENII can calculate doses to maximum individuals based on the quantity of materials released, meteorological conditions, location of the individual, and the characteristics of the release. Table 12 provides the input parameters used to calculate doses to the maximally exposed individuals. 
HNF-1844, Rev. 0

Table 12. GENII Input Parameters to Calculate Doses to the Maximally Exposed Individuals

\begin{tabular}{|c|c|c|}
\hline Parameter & $\begin{array}{l}\text { Maximum Onsite } \\
\text { individual }\end{array}$ & $\begin{array}{l}\text { Maximum Offsite } \\
\text { individual }\end{array}$ \\
\hline GENII Inputs $^{(2)}$ & \multicolumn{2}{|c|}{ Value } \\
\hline Atmospheric conditions, $\mathrm{X} / \mathrm{Q}^{(\mathrm{b})}$ & $1.2 \mathrm{E}-03$ & $1.4 \mathrm{E}-04$ \\
\hline Exposure to ground contamination ${ }^{(b)}$ & 2,000 hours/year & 8,760 hours/year \\
\hline Release height & Ground level & Ground level \\
\hline Building wake & Yes & Yes \\
\hline Release source term development & \multicolumn{2}{|c|}{ Value } \\
\hline Initial source term & Table 1 & Table 1 \\
\hline Release duration & 12 hours & 24 hours \\
\hline Fraction aerosolized & 10 percent & 10 percent \\
\hline Respirable release fraction & 5 percent & 5 percent \\
\hline
\end{tabular}

(a) Inputs or modifications to GENII default values.

(b) Source: PNNL 1996

$\mathrm{X} / \mathrm{Q}$ is the air pollutant concentration (mass per volume) divided by the pollutant emission rule (mass per time) 


\subsubsection{Nonradiological Impacts From Routine Transportation Activities}

Impacts to the public from nonradiological causes are also evaluated. This involves fatalities from pollutants emitted by the vehicle engine exhaust during routine transportation. Based on the information contained in Rao et al. (1982), the types of pollutants that are present and can impact the public are sulfur oxides $\left(\mathrm{SO}_{\mathrm{x}}\right)$, particulates, nitrogen oxides $\left(\mathrm{NO}_{x}\right)$, carbon monoxide $(\mathrm{CO})$, hydrocarbons $(\mathrm{HC})$, and photochemical oxidants $\left(\mathrm{O}_{\mathrm{x}}\right)$. Of these pollutants, Rao et al. (1982) determined that the majority of the health effects are due to $\mathrm{SO}_{\mathrm{x}}$ and the particulates. Unit risk factors (fatalities per kilometer) for truck shipments were developed by Rao et al. (1982) for travel in urban population zones $(1.0 \mathrm{E}-07 / \mathrm{km}$ for truck).

4.1.4 Nonradiological Impacts from Transportation Accidents. This section describes the analyses performed to assess nonradiological impacts to the public. Nonradiological accident impacts are defined here as fatalities resulting from potential vehicular accidents involving the shipments. The data that supports these unit risk factors combines the effects on the truck crew and others involved in the accident; therefore, nonradiological vehicular accident impacts do not distinguish between the crew and the public.

Hand calculations were performed using "unit-risk factors" (fatalities per $\mathrm{km}$ of travel) to derive estimates of the nonradiological impacts. The nonradiological impacts were calculated by multiplying the unit risk factors by the round trip shipping distances (one-way shipping distances shown in Table 5 multiplied by 2) for all of the shipments in each shipping option. Nonradiological unit risk factors for vehicular accidents, shown in Table 13, were taken from Saricks and Kvitek (1994) and DOE (1996). These risk factors, in units of fatalities-per-km of travel in rural and urban population zones, are multiplied by the total distance traveled in each zone by all of the shipments and then summed to calculate the expected number of nonradiological fatalities. The unit risk factor for travel in suburban zones was represented by the average of the rural and urban unit risk factors given by Saricks and Kvitek (1994). 
HNF-1844, Rev. 0

Table 13. Route Specific Fatal Accident Rates for Combination-Truck Shipments

\begin{tabular}{|c|c|c|c|}
\hline \multirow{2}{*}{ Transport Route } & \multicolumn{3}{|c|}{$\begin{array}{c}\text { Combination-Truck Highway Fatality Rate } \\
\text { (Fatalities per Kilometer) }\end{array}$} \\
\hline & Rural & Suburban $^{(2)}$ & Urban \\
\hline \multicolumn{4}{|c|}{ Unirradiated target materials, not including Ra-226 } \\
\hline ORNL to 300 Area & $1.54 \mathrm{E}-08$ & $2.49 \mathrm{E}-08$ & 3.77E-08 \\
\hline \multicolumn{4}{|c|}{ Unirradiated target materials, including Ra-226 } \\
\hline 300 Area to $\mathrm{FFTF}^{(0)}$ & $5.30 \mathrm{E}-08$ & $5.30 \mathrm{E}-08$ & $5.30 \mathrm{E}-08$ \\
\hline \multicolumn{4}{|c|}{ Irradiated targets } \\
\hline FFTF to 325 Building & 5.30E-08 & 5.30E-08 & $5.30 \mathrm{E}-08$ \\
\hline \multicolumn{4}{|c|}{ Separated isotopes } \\
\hline 325 building to Pasco/Kennewick/Richland Airport & $1.47 \mathrm{E}-08$ & $1.14 \mathrm{E}-08$ & $8.00 \mathrm{E}-09$ \\
\hline Boston Airport to Du-Pont Merck & $6.23 \mathrm{E}-08$ & 3.77E-08 & $1.30 \mathrm{E}-08$ \\
\hline Chicago Airport to Amersham Mediphysics & $1.39 \mathrm{E}-08$ & $3.36 \mathrm{E}-08$ & 5.33E-08 \\
\hline St. Louis Airport to Mallinckrodt & $1.23 \mathrm{E}-08$ & $2.77 \mathrm{E}-08$ & $4.30 \mathrm{E}-08$ \\
\hline \multicolumn{4}{|c|}{ Liquid and solid waste } \\
\hline 300 Area to the 200 East and West Areas ${ }^{(0)}$ & $5.30 \mathrm{E}-08$ & $5.30 \mathrm{E}-08$ & $5.30 \mathrm{E}-08$ \\
\hline
\end{tabular}

(a) Average of the rural and urban fatality rates

(b) Taken from DOE 1996 
HNF-1844, Rev. 0

\subsection{INPUT PARAMETERS FOR AIR SHIPMENTS}

This section provides the RADTRAN 4 input parameters used to characterize air transport segments, model routine radiation exposures to the public and workers, and describe and quantify the impacts of accidents involving air shipments of medical isotopes.

\subsubsection{Radiological Impacts of Routine Transport}

Air transport of the shipping casks from the Tri-Cities Airport to the radiopharmaceutical suppliers is expected to be accomplished by commercial air transport. As a bounding assumption, air transport is assured to be on commercial passenger flights (during routine operations isotope products would only be transported on passenger flights in rare instances. The shipping casks would be unloaded from their truck shipments at the Tri-Cities Airport or other local airport, loaded aboard the aircraft, and shipped to the destination airport (i.e., Chicago, IL, Boston, MA, and St. Louis, MO), where they would be picked up and transported by truck to the pharmacological suppliers. Each shipment was assumed to be transferred at the carrier's central distribution hub to a connecting flight to the final destination. Two loading and unloading procedures were included in the analysis of each air shipment; i.e., loading the flight at the Tri-Cities Airport and an unloading/loading cycle at the air carriers hub, and unloading at the destination airport. The sum of these two procedures was modeled in RADTRAN 4 as one handling.

Airport handler exposures were modeled in two ways, depending on the size of the package. For small packages (maximum dimension less than 0.5 meter [1.6 ft]), the dose to workers is modeled as 2.5E-4 rem/handling/TI (Neuhauser and Kanipe 1995). Otherwise, the RADTRAN 4 calculations were performed by multiplying together the radiation dose rate, number of handlers, and length of exposure. In addition to the loading and unloading of aircraft, transit of the package through the airports was modeled as a stop that exposes 1000 persons at an average exposure distance of 50 meters $(164 \mathrm{ft})$.

Radiation exposures to air crews are calculated by RADTRAN using a simple model that uses an average exposure distance and number of exposed persons. The integrated crew exposure is calculated as the product of the dose rate at a specific distance from the source, the number of crew aboard the aircraft, and the transit time. The doses to aircraft passengers and flight attendants are calculated using an empirical value of $3 \mathrm{E}-05 \mathrm{rem} / \mathrm{hr} / \mathrm{TI}^{1}$ (Neuhauser and Kanipe 1995). The integrated exposures are the product of the number of from package surface. 
shipments, TI value, number of exposed persons, the empirical TI-to-dose-rate conversion factor generated by RADTRAN, and transit time.

The RADTRAN 4 input parameters used in calculating the routine doses from the air transport legs of the isotope shipments are presented in Table 14. The sources of the input data are also shown in the Table.

\subsubsection{Radiological Accidents.}

Potential accident environments are defined and their likelihood of occurrence are modeled using an approach that divides the entire spectrum of potential aircraft accident environments into six "accident severity" categories. The severity categories are based on event trees originally developed for spent fuel shipped by truck and rail (Wilmot, 1981). The conditional probabilities of occurrence of each accident severity were developed from these data. The overall probability of an accident of a particular severity is calculated as the product of the base accident probability (accident rate) and the conditional probability. Accident rate data for aircraft accidents are shown in Table 15. Accident rate data for air accidents are taken from Ross (1994).

The source term from which members of the public could receive a dose in the event of an accident depends on three factors in the event that a package fails and its protection is compromised. Release fractions define the fraction of the package inventory that would be released into the environment. Aerosol fraction defines the quantity of released material that would be lofted into the plume, and respirable fraction defines the quantity of aerosolized material that could be inhaled by human beings. These parameters are quantified for each type of radioactive material that would be shipped by air are shown in Table 15 . 
HNF-1844, Rev. 0

Table 14. RADTRAN 4 Input Parameters for Passenger Air Shipments

\begin{tabular}{|l|c|l|}
\hline \multicolumn{1}{|c|}{ Parameter } & Value & \multicolumn{1}{|c|}{ Source } \\
\hline $\begin{array}{l}\text { Population Density, Takeoff and } \\
\text { Landing }\end{array}$ & $\begin{array}{c}3861 \text { people per } \\
\mathrm{km}^{2}\end{array}$ & $\begin{array}{l}\text { NRC (1977); represents high-density urban } \\
\text { area }\end{array}$ \\
\hline Population Density, In-flight & $\begin{array}{c}719 \mathrm{people}^{\mathrm{k}} \mathrm{ker} \\
\mathrm{km}^{2}\end{array}$ & $\begin{array}{l}\text { NRC (1977); represents medium-density } \\
\text { suburban area }\end{array}$ \\
\hline Velocity & $692 \mathrm{~km} / \mathrm{hr}$ & NRC (1977) and Madsen et al. (1983) \\
\hline Crew/flight & 3 & NRC (1977) and Madsen et al. (1983) \\
\hline Crew exposure distance & $15.2 \mathrm{~m}$ & Neuhauser and Kanipe (1995) \\
\hline Passengers/flight & 78 & Not applicable to cargo air shipments \\
\hline Stop time & $0.00083 \mathrm{hr} / \mathrm{km}$ & Neuhauser and Kanipe (1995) \\
\hline Minimum stop time & $1 \mathrm{hr}$ & Neuhauser and Kanipe (1995) \\
\hline Number of persons exposed at stops & 1000 & Neuhauser and Kanipe (1995) \\
\hline Exposure distance when stopped & $50 \mathrm{~m}$ & Neuhauser and Kanipe (1995) \\
\hline Accident rate, Takeoff/landing & $6.9 \mathrm{E}-10 / \mathrm{km}$ & Ross (1994) \\
\hline Accident rate, in-flight & $2.8 \mathrm{E}-06$ per flight & Ross (1994) \\
\hline $\begin{array}{l}\text { Transport Index (dose rate at } 1 \mathrm{~m} \text { from } \\
\text { side of package) }\end{array}$ & see Table 6 & Representative dose rate \\
\hline
\end{tabular}


Table 15. RADTRAN Accident Impact Parameters for Air Shipments

\begin{tabular}{|c|c|c|c|c|}
\hline $\begin{array}{l}\text { Accident Rate } \\
\text { - Air Takeoff/Landing } \\
\text { - Air In-flight }\end{array}$ & \multicolumn{4}{|c|}{$\begin{array}{l}2.8 \mathrm{E}-06 / \text { flight } \\
6.9 \mathrm{E}-10 / \mathrm{km}\end{array}$} \\
\hline Severity Category Parameters & Probability ${ }^{(a)}$ & $\begin{array}{l}\text { Release } \\
\text { Fraction }^{(b)}\end{array}$ & $\begin{array}{c}\text { Aerosol } \\
\text { Fraction }{ }^{(c)}\end{array}$ & $\begin{array}{l}\text { Respirable } \\
\text { Fraction }^{(c)}\end{array}$ \\
\hline Category 1 . & $\begin{array}{l}\mathrm{T} ; 0.208 \\
\mathrm{I} ; 0.230\end{array}$ & 0 & 1.0 & 1.0 \\
\hline Category 2. & $\begin{array}{l}\text { T; } 0.504 \\
\text { I; } 0.130\end{array}$ & 0 & 1.0 & 1.0 \\
\hline Category 3 & $\begin{array}{l}\text { T; } 0.050 \\
\text { I; } 0.385\end{array}$ & 1.0 & 1.0 & 1.0 \\
\hline Category 4. & $\begin{array}{l}\text { T; } 0.060 \\
\text { I; } 0.014\end{array}$ & 1.0 & 1.0 & 1.0 \\
\hline Category 5. & $\begin{array}{l}\text { T; } 0.128 \\
\text { I; } 0.217\end{array}$ & 1.0 & 1.0 & 1.0 \\
\hline Category 6. & $\begin{array}{l}\mathrm{T} ; 0.014 \\
\mathrm{I} ; 0.024\end{array}$ & 1.0 & 1.0 & 1.0 \\
\hline
\end{tabular}

(a) Conditional probability of encountering accident environment equivalent to Category 1 impact and thermal environments. Given for in-flight (I) and Take-off/landing (T) portions of air trip.

(b) Release fractions are the fraction of the package inventory release from the package and are given for Type A and Type B packages for each severity category.

(c) Aerosol and respirable fractions are the fractions of the released material that are in aerosol and respirable form, respectively, and are given separately for releases from packages for each severity category. 


\subsection{RESULTS OF THE TRANSPORTATION IMPACT ANALYSIS}

This section presents the results of the transportation impact analysis. The impacts have been calculated for each isotope, based on future market demand and the number of irradiation cycles required to meet this demand (i.e., one shipment for each irradiation cycle). It was also assumed, based on the waste volume estimates, that 2 liquid waste and 35 solid waste shipments will be performed annually.

Section 5.1 presents the results of the radiological and nonradiological transportation accident impact analysis and Section 5.2 presents the results of the routine or incident free, including radiological and nonradiological impacts, transportation impact analysis.

\subsection{RADIOLOGICAL AND NONRADIOLOGICAL TRANSPORTATION ACCIDENT IMPACT ANALYSIS}

\subsubsection{Radiological Impacts due to Transportation Accidents}

This section describes the results of the radiological impact analysis for the public and the maximum individuals from transportation accidents. Truck accident impacts are presented in Section 5.1.1.1 and air transportation impacts are presented in Section 5.1.1.2.

5.1.1.1 Radiological Impacts due to Truck Transportation Accidents. Tables 16 through 20 presents the radiological accident impacts calculated in this study. Table 16 presents the radiological impacts of shipping irradiated targets from FFTF to the 325 Building, shipping the Ra-226 target from 325 Building to FFTF, and waste shipments from the 300 Area to waste handling facilities. Table 17 presents the per-shipment impacts of transporting separated medical isotopes from the 325 Building to the Tri-Cities Airport in Pasco, WA. Tables 18,19 , and 20 presents the impacts of transporting isotope products from the destination airports to the pharmaceutical distributors. 
Table 16: Radiological Impacts due to Truck Transportation Accidents during Shipping of Irradiated Targets from FFTF to the 325 Building

\begin{tabular}{|c|c|c|c|c|}
\hline Target Isotope* & $\begin{array}{l}\text { Estimated Number } \\
\text { of Annual } \\
\text { Shipments }\end{array}$ & $\begin{array}{l}\text { Radiological } \\
\text { Impacts per } \\
\text { Shipment } \\
\text { (Person-rem/ } \\
\text { Shipment) }\end{array}$ & $\begin{array}{c}\text { Annual } \\
\text { Radiological } \\
\text { Impacts } \\
\text { (Person-rem/Year) }\end{array}$ & $\begin{array}{l}\text { Health Effects } \\
\text { (LCFs/year) }^{\left({ }^{(2)(b)}\right.}\end{array}$ \\
\hline \multicolumn{5}{|c|}{ Shipments of Irradiated targets from FFTF to PNNL } \\
\hline Ac-227 & 1 & $6.19 \mathrm{E}-10$ & $6.19 \mathrm{E}-10$ & $<1 \mathrm{E}-10$ \\
\hline $\mathrm{Au}-198$ & 25 & $2.52 \mathrm{E}-13$ & $6.30 \mathrm{E}-12$ & $<1 \mathrm{E}-10$ \\
\hline Cd-109 & 1 & $9.92 \mathrm{E}-13$ & $9.92 \mathrm{E}-13$ & $<1 \mathrm{E}-10$ \\
\hline $\mathrm{Cu}-64$ & 25 & $2.53 \mathrm{E}-13$ & $6.33 \mathrm{E}-12$ & $<1 \mathrm{E}-10$ \\
\hline $\mathrm{Cu}-67$ & 25 & $2.51 \mathrm{E}-13$ & $6.28 \mathrm{E}-12$ & $<1 \mathrm{E}-10$ \\
\hline Gd-153 & 1 & $3.79 \mathrm{E}-10$ & $3.79 \mathrm{E}-10$ & $<1 \mathrm{E}-10$ \\
\hline Ho-166 & 25 & $2.51 \mathrm{E}-13$ & $6.28 \mathrm{E}-12$ & $<1 \mathrm{E}-10$ \\
\hline I- 125 & 1 & $1.15 \mathrm{E}-12$ & $1.15 \mathrm{E}-12$ & $<1 \mathrm{E}-10$ \\
\hline I-131 & 10 & $2.66 \mathrm{E}-13$ & $2.66 \mathrm{E}-12$ & $<1 \mathrm{E}-10$ \\
\hline Ir -192 & 1 & $2.44 \mathrm{E}-10$ & $2.44 \mathrm{E}-10$ & $<1 \mathrm{E}-10$ \\
\hline Lu-177 & 10 & $2.51 \mathrm{E}-13$ & $2.51 \mathrm{E}-12$ & $<1 \mathrm{E}-10$ \\
\hline Mo-99 & 25 & $2.87 \mathrm{E}-13$ & $7.18 \mathrm{E}-12$ & $<1 \mathrm{E}-10$ \\
\hline Os-194 & 1 & $4.44 \mathrm{E}-12$ & $4.44 \mathrm{E}-12$ & $<1 \mathrm{E}-10$ \\
\hline P-32 & 5 & $2.51 \mathrm{E}-13$ & $1.26 \mathrm{E}-12$ & $<1 \mathrm{E}-10$ \\
\hline P-33 & 3 & $2.54 \mathrm{E}-13$ & $6.35 \mathrm{E}-13$ & $<1 \mathrm{E}-10$ \\
\hline Pd-103 & 5 & $2.55 \mathrm{E}-13$ & $1.28 \mathrm{E}-12$ & $<1 \mathrm{E}-10$ \\
\hline Pt-195m & 5 & $2.51 \mathrm{E}-13$ & $1.26 \mathrm{E}-12$ & $<1 \mathrm{E}-10$ \\
\hline Re-186 & 10 & $2.85 \mathrm{E}-13$ & $2.85 \mathrm{E}-12$ & $<1 \mathrm{E}-10$ \\
\hline Sc-47 & 25 & $2.51 \mathrm{E}-13$ & $6.28 \mathrm{E}-12$ & $<1 \mathrm{E}-10$ \\
\hline $\mathrm{Se}-75$ & 1 & $2.51 \mathrm{E}-13$ & $2.51 \mathrm{E}-13$ & $<1 \mathrm{E}-10$ \\
\hline Sm-145 & 1 & $2.55 \mathrm{E}-13$ & $2.55 \mathrm{E}-13$ & $<1 \mathrm{E}-10$ \\
\hline Sm-153 & 25 & $2.51 \mathrm{E}-13$ & $6.28 \mathrm{E}-12$ & $<1$ E-10 \\
\hline
\end{tabular}


HNF-1844, Rev. 0

Table 16. Radiological Impacts due to Truck Transportation Accidents during Shipping of Irradiated Targets from FFTF to the 325 Building

\begin{tabular}{|c|c|c|c|c|}
\hline Target Isotope* & $\begin{array}{l}\text { Estimated Number } \\
\text { of Annual } \\
\text { Shipments }\end{array}$ & $\begin{array}{l}\text { Radiological } \\
\text { Impacts per } \\
\text { Shipment } \\
\text { (Person-rem/ } \\
\text { Shipment) }\end{array}$ & $\begin{array}{c}\text { Annual } \\
\text { Radiological } \\
\text { Impacts } \\
\text { (Person-rem/Year) }\end{array}$ & $\begin{array}{l}\text { Health Effects } \\
\text { (LCFs/year) }^{(2)(b)}\end{array}$ \\
\hline \multicolumn{5}{|c|}{ Shipments of Irradiated targets from FFTF to PNNL } \\
\hline $\mathrm{Sn}-117 \mathrm{~m}$ & 5 & $1.22 \mathrm{E}-12$ & $6.10 \mathrm{E}-12$ & $<1 \mathrm{E}-10$ \\
\hline Sr-85 & 1 & $2.53 \mathrm{E}-13$ & $2.53 \mathrm{E}-13$ & $<1 \mathrm{E}-10$ \\
\hline $\mathrm{Sr}-89$ & 3 & $2.53 \mathrm{E}-13$ & $6.33 \mathrm{E}-13$ & $<1 \mathrm{E}-10$ \\
\hline Th-228 & 1 & See Ac-227 & See Ac-227 & See Ac-227 \\
\hline Th-229 & 1 & See Ac-227 & See Ac-227 & See Ac- 227 \\
\hline W-188 & 1 & $1.07 \mathrm{E}-11$ & $1.07 \mathrm{E}-11$ & $<1 \mathrm{E}-10$ \\
\hline $\mathrm{Xe}-127$ & 3 & $2.51 \mathrm{E}-13$ & $6.28 \mathrm{E}-13$ & $<1 \mathrm{E}-10$ \\
\hline $\mathrm{Y}-91$ & 1 & $2.51 \mathrm{E}-13$ & $2.51 \mathrm{E}-13$ & $<1 \mathrm{E}-10$ \\
\hline \multicolumn{5}{|c|}{ Shipments from the 300 Area to FFTF and Waste Handling Facilities } \\
\hline $\begin{array}{l}\text { Ra-226 target to } \\
\text { FFTF }\end{array}$ & 1 & $5.32 \mathrm{E}-11$ & $5.32 \mathrm{E}-11$ & $<1 \mathrm{E}-10$ \\
\hline $\begin{array}{l}\text { Liquid Waste to } \\
200 \text { East Area }\end{array}$ & 2 & $6.23 \mathrm{E}-05$ & $1.25 \mathrm{E}-04$ & $6.23 \mathrm{E}-08$ \\
\hline $\begin{array}{l}\text { Solid Waste to } 200 \\
\text { West Area }\end{array}$ & 35 & $3.57 \mathrm{E}-16$ & 1.25E-14 & $<1 \mathrm{E}-10$ \\
\hline
\end{tabular}

(a) Calculated using the methodology prescribed in ICRP 60.

(b) Accident impacts are less than $1 \mathrm{E}-10$ health effects; insignificant contributors to annual and life-cycle transportation impacts.

"Impacts are the result of the release of the medical isotope and other radiological constituents of the 
HNF-1844, Rev. 0

Table 17. Radiological Impacts due to Truck Transportation Accidents During Shipping of Isotope Products from the 325 Building to Pasco Airport

\begin{tabular}{|c|c|c|c|c|}
\hline $\begin{array}{l}\text { Desired Medical } \\
\text { Isotope Being } \\
\text { Shipped }\end{array}$ & $\begin{array}{c}\text { Estimated number } \\
\text { of annual } \\
\text { shipments }\end{array}$ & $\begin{array}{l}\text { Radiological } \\
\text { Impacts per } \\
\text { Shipment } \\
\text { (person-rem/ } \\
\text { shipment) }\end{array}$ & $\begin{array}{c}\text { Annual } \\
\text { Radiological } \\
\text { Impacts } \\
\text { (person-rem/year) }\end{array}$ & $\begin{array}{l}\text { Health Effects } \\
\text { (LCFs/year) }^{(\mathrm{a})(\mathrm{b})}\end{array}$ \\
\hline Ac-227 & 1 & $1.01 \mathrm{E}-01$ & $1.01 \mathrm{E}-01$ & $5.06 \mathrm{E}-05$ \\
\hline $\mathrm{Au}-198$ & 25 & $2.11 \mathrm{E}-07$ & $5.28 \mathrm{E}-06$ & $2.64 \mathrm{E}-09$ \\
\hline $\mathrm{Cd}=109$ & 1 & $6.79 \mathrm{E}-05$ & $6.79 \mathrm{E}-05$ & $3.40 \mathrm{E}-08$ \\
\hline $\mathrm{Cu}-64$ & 25 & $3.03 \mathrm{E}-09$ & $7.58 \mathrm{E}-08$ & $<1 \mathrm{E}-10$ \\
\hline $\mathrm{Cu}-67$ & 25 & $2.30 \mathrm{E}-09$ & $5.75 \mathrm{E}-08$ & $<1 \mathrm{E}-10$ \\
\hline Gd-153 & 1 & $1.78 \mathrm{E}-05$ & $1.78 \mathrm{E}-05$ & $8.90 \mathrm{E}-09$ \\
\hline Ho-166 & 25 & $3.42 \mathrm{E}-08$ & $8.55 \mathrm{E}-07$ & $4.28 \mathrm{E}-10$ \\
\hline I-125 & 1 & $1.18 \mathrm{E}-03$ & $1.18 \mathrm{E}-03$ & $5.90 \mathrm{E}-07$ \\
\hline I-131 & 10 & $1.55 \mathrm{E}-06$ & $1.55 \mathrm{E}-05$ & $7.75 \mathrm{E}-09$ \\
\hline Ir-192 & 1 & $3.78 \mathrm{E}-07$ & $3.78 \mathrm{E}-07$ & $1.89 \mathrm{E}-10$ \\
\hline Lu-177 & 10 & $8.21 \mathrm{E}-09$ & $8.21 \mathrm{E}-08$ & $<1 \mathrm{E}-10$ \\
\hline Mo-99 & 25 & $6.15 \mathrm{E}-06$ & $1.54 \mathrm{E}-04$ & $7.69 \mathrm{E}-08$ \\
\hline Os-194 & 1 & $2.09 \mathrm{E}-06$ & $2.09 \mathrm{E}-06$ & $1.05 \mathrm{E}-09$ \\
\hline P-32 & 5 & $4.46 \mathrm{E}-08$ & $2.23 \mathrm{E}-07$ & 1.12E-10 \\
\hline P-33 & 3 & $4.03 \mathrm{E}-07$ & $1.01 \mathrm{E}-06$ & $5.04 \mathrm{E}-10$ \\
\hline Pd-103 & 5 & $4.29 \mathrm{E}-07$ & $2.15 \mathrm{E}-06$ & $1.07 \mathrm{E}-09$ \\
\hline Pt-195m & 5 & $2.92 \mathrm{E}-08$ & $1.46 \mathrm{E}-07$ & $<1 \mathrm{E}-10$ \\
\hline $\operatorname{Re}-186$ & 10 & $4.90 \mathrm{E}-06$ & $4.90 \mathrm{E}-05$ & $2: 45 \mathrm{E}-08$ \\
\hline Sc- 47 & 25 & $1.52 \mathrm{E}-08$ & $3.80 \mathrm{E}-07$ & $1.90 \mathrm{E}-10$ \\
\hline $\mathrm{Se}-75$ & 1 & $9.86 \mathrm{E}-08$ & $9.86 \mathrm{E}-08$ & $<1 \mathrm{E}-10$ \\
\hline Sm-145 & 1 & $6.11 \mathrm{E}-07$ & $6.11 \mathrm{E}-07$ & $3.06 \mathrm{E}-10$ \\
\hline $\mathrm{Sm}-153$ & 25 & $3.64 \mathrm{E}-08$ & $9.10 \mathrm{E}-07$ & $4.55 \mathrm{E}-10$ \\
\hline $\mathrm{Sn}-117 \mathrm{~m}$ & 5 & $5.78 \mathrm{E}-08$ & $2.89 \mathrm{E}-07$ & $1.45 \mathrm{E}-10$ \\
\hline
\end{tabular}


HNF-1844, Rev. 0

Table 17. Radiological Impacts due to Truck Transportation Accidents During Shipping of Isotope Products from the 325 Building to Pasco Airport

\begin{tabular}{|l|c|c|c|c|}
\hline $\begin{array}{c}\text { Desired Medical } \\
\text { Isotope Being } \\
\text { Shipped }\end{array}$ & $\begin{array}{c}\text { Estimated number } \\
\text { of annual } \\
\text { shipments }\end{array}$ & $\begin{array}{c}\text { Radiological } \\
\text { Impacts per } \\
\text { Shipment } \\
\text { (person-rem/ } \\
\text { shipment) }\end{array}$ & $\begin{array}{c}\text { Annual } \\
\text { Radiological } \\
\text { Impacts } \\
\text { (person-rem/year) }\end{array}$ & $\begin{array}{c}\text { Health Effects } \\
\text { (LCFs/year) }^{(\mathbf{a})(\mathrm{b})}\end{array}$ \\
\hline Sr-85 & 1 & $2.58 \mathrm{E}-07$ & $2.58 \mathrm{E}-07$ & $1.29 \mathrm{E}-10$ \\
\hline Sr-89 & 3 & $4.45 \mathrm{E}-07$ & $1.11 \mathrm{E}-06$ & $5.56 \mathrm{E}-10$ \\
\hline Th-228 & 1 & $1.30 \mathrm{E}-02$ & $1.30 \mathrm{E}-02$ & $6.50 \mathrm{E}-06$ \\
\hline Th-229 & 1 & See Th-228 & See Th-228 & See Th-228 \\
\hline W-188 & 3 & $1.27 \mathrm{E}-04$ & $1.27 \mathrm{E}-04$ & $6.35 \mathrm{E}-08$ \\
\hline Xe-127 & 1 & $5.90 \mathrm{E}-07$ & $1.48 \mathrm{E}-06$ & $7.38 \mathrm{E}-10$ \\
\hline Y-91 & 1 & $1.64 \mathrm{E}-07$ & $1.64 \mathrm{E}-07$ & $<1 \mathrm{E}-10$ \\
\hline
\end{tabular}

(a) Calculated using the methodology prescribed in ICRP 60.

(b) Accident impacts are less than IE-10 health effects; insignificant contributors to annual and life-cycle transportation impacts.

Impacts are the result of the release of the medical isotope and radiological impurities. 
Table 18. Radiological Impacts due to Truck Transportation Accidents during Shipping Medical Isotopes from Boston, Ma. Airport to Dupont-Merck

\begin{tabular}{|c|c|c|c|c|}
\hline Isotope Product & $\begin{array}{c}\text { Estimated } \\
\text { Number of } \\
\text { Annual Shipments }\end{array}$ & $\begin{array}{l}\text { Radiological } \\
\text { Impacts per } \\
\text { Shipment } \\
\text { (person-rem/ } \\
\text { shipment) }\end{array}$ & $\begin{array}{c}\text { Annual } \\
\text { Radiological } \\
\text { Impacts } \\
\text { (person-rem/year) }\end{array}$ & $\begin{array}{l}\text { Health Effects } \\
\text { (LCFs/year) }^{(\varrho)}\end{array}$ \\
\hline Ac-227 & 1 & $5.67 \mathrm{E}-01$ & $5.67 \mathrm{E}-01$ & $2.83 \mathrm{E}-04$ \\
\hline $\mathrm{Au}-198$ & 25 & $1.18 \mathrm{E}-06$ & $2.95 \mathrm{E}-05$ & $1.48 \mathrm{E}-08$ \\
\hline Cd-109 & 1 & $3.81 \mathrm{E}-04$ & $3.81 \mathrm{E}-04$ & $1.91 E-07$ \\
\hline Cu-64 & 25 & $1.70 \mathrm{E}-08$ & $4.25 \mathrm{E}-07$ & $2.13 \mathrm{E}-10$ \\
\hline $\mathrm{Cu}-67$ & 25 & $1.29 \mathrm{E}-08$ & $3.23 \mathrm{E}-07$ & $1.61 \mathrm{E}-10$ \\
\hline Gd-153 & 1 & $9.96 \mathrm{E}-05$ & $9.96 \mathrm{E}-05$ & $4.98 \mathrm{E}-08$ \\
\hline Ho-166 & 25 & $1.91 \mathrm{E}-07$ & $4.78 \mathrm{E}-06$ & $2.39 \mathrm{E}-09$ \\
\hline $\mathrm{I}-125$ & 1 & $6.59 \mathrm{E}-03$ & $6.59 \mathrm{E}-03$ & $3.30 \mathrm{E}-06$ \\
\hline$I-131$ & 10 & $8.44 \mathrm{E}-06$ & $8.44 \mathrm{E}-05$ & $4.22 \mathrm{E}-08$ \\
\hline Ir-192 & 1 & $2.12 \mathrm{E}-06$ & $2.12 \mathrm{E}-06$ & $1.06 \mathrm{E}-09$ \\
\hline Lu-177 & 10 & $4.60 \mathrm{E}-08$ & $4.60 \mathrm{E}-07$ & $2.30 \mathrm{E}-10$ \\
\hline Mo-99 & 25 & $3.45 \mathrm{E}-05$ & $8.63 \mathrm{E}-04$ & $4.31 \mathrm{E}-07$ \\
\hline Os-194 & 1 & $1.17 \mathrm{E}-05$ & $1.17 \mathrm{E}-05$ & $5.85 \mathrm{E}-09$ \\
\hline P-32 & 5 & $2.50 \mathrm{E}-07$ & $1.25 \mathrm{E}-06$ & $6.25 \mathrm{E}-10$ \\
\hline P-33 & 3 & $.2 .26 \mathrm{E}-06$ & $5.65 \mathrm{E}-06$ & $2.83 \mathrm{E}-09$ \\
\hline Pd-103 & 5 & $2.41 \mathrm{E}-06$ & $1.21 \mathrm{E}-05$ & $6.03 \mathrm{E}-09$ \\
\hline Pt-195m & 5 & $1.64 \mathrm{E}-07$ & $8.20 \mathrm{E}-07$ & $4.10 \mathrm{E}-10$ \\
\hline Re-186 & 10 & $2.75 \mathrm{E}-05$ & $2.75 \mathrm{E}-04$ & $1.38 \mathrm{E}-07$ \\
\hline Sc-47 & 25 & $8.53 \mathrm{E}-08$ & 2.13E-06 & $1.07 \mathrm{E}-09$ \\
\hline Se-75 & 1 & $5.53 \mathrm{E}-07$ & $5.53 \mathrm{E}-07$ & $2.77 \mathrm{E}-10$ \\
\hline Sm-145 & 1 & $3.43 \mathrm{E}-06$ & $3.43 \mathrm{E}-06$ & $1.72 \mathrm{E}-09$ \\
\hline Sm-153 & 25 & $2.04 \mathrm{E}-07$ & $5.10 \mathrm{E}-06$ & $2.55 \mathrm{E}-09$ \\
\hline $\mathrm{Sn}-117 \mathrm{~m}$ & 5 & $3.24 \mathrm{E}-07$ & $1.62 \mathrm{E}-06$ & $8.10 \mathrm{E}-10$ \\
\hline
\end{tabular}


HNF-1844, Rev. 0

Table 18. Radiological Impacts due to Truck Transportation Accidents during Shipping Medical Isotopes from Boston, Ma. Airport to Dupont-Merck

\begin{tabular}{|l|c|c|c|c|}
\hline \multicolumn{1}{|c|}{ Isotope Product* } & $\begin{array}{c}\text { Estimated } \\
\text { Number of } \\
\text { Annual Shipments }\end{array}$ & $\begin{array}{c}\text { Radiological } \\
\text { Impacts per } \\
\text { Shipment } \\
\text { (person-rem/ } \\
\text { shipment) }\end{array}$ & $\begin{array}{c}\text { Annual } \\
\text { Radiological } \\
\text { Impacts } \\
\text { (person-rem/year) }\end{array}$ & $\begin{array}{c}\text { Health Effects } \\
\text { (LCFs/year) }\end{array}$ \\
\hline Sr-85 & 1 & $1.04 \mathrm{E}-06$ & $1.04 \mathrm{E}-06$ & $5.20 \mathrm{E}-10$ \\
\hline Sr-89 & 3 & $1.80 \mathrm{E}-06$ & $4.50 \mathrm{E}-06$ & $2.25 \mathrm{E}-09$ \\
\hline Th-228 & 1 & $7.27 \mathrm{E}-02$ & $7.27 \mathrm{E}-02$ & $3.64 \mathrm{E}-05$ \\
\hline Th-229 & 1 & See Th-228 & See Th-228 & See Th-228 \\
\hline W-188 & 1 & $7.17 \mathrm{E}-04$ & $7.17 \mathrm{E}-04$ & $3.59 \mathrm{E}-07$ \\
\hline Xe-127 & 3 & $3.31 \mathrm{E}-06$ & $8.28 \mathrm{E}-06$ & $4.14 \mathrm{E}-09$ \\
\hline Y-91 & 1 & $6.61 \mathrm{E}-07$ & $6.61 \mathrm{E}-07$ & $3.31 \mathrm{E}-10$ \\
\hline
\end{tabular}

(a) Calculated using the methodology prescribed in ICRP 60.

"Impacts are the result of the release of the medical isotope and radiological impurities. 
Table 19. Radiological Impacts due to Truck Transportation Impacts during Shipping Medical Isotopes from Chicago, Il. Airport to Amersham Mediphysics

\begin{tabular}{|c|c|c|c|c|}
\hline Isotope & $\begin{array}{c}\text { Estimated Number } \\
\text { of Annual } \\
\text { Shipments }\end{array}$ & $\begin{array}{l}\text { Radiological } \\
\text { Impacts per } \\
\text { Shipment } \\
\text { (person-rem/ } \\
\text { shipment) }\end{array}$ & $\begin{array}{c}\text { Annual } \\
\text { Radiological } \\
\text { Impacts } \\
\text { (person-rem/year) }\end{array}$ & $\begin{array}{l}\text { Health Effects } \\
\text { (LCFs/year) }^{(a)}\end{array}$ \\
\hline Ac- 227 & 1 & $9.96 \mathrm{E}-01$ & $9.96 \mathrm{E}-01$ & $4.98 \mathrm{E}-04$ \\
\hline $\mathrm{Au}-198$ & 25 & $2.09 \mathrm{E}-06$ & $5.23 E-05$ & $2.61 \mathrm{E}-08$ \\
\hline Cd-109 & 1 & $6.85 \mathrm{E}-04$ & $6.85 \mathrm{E}-04$ & $3.43 \mathrm{E}-07$ \\
\hline $\mathrm{Cu}-64$ & 25 & $2.98 \mathrm{E}-08$ & $7.45 \mathrm{E}-07$ & $3.73 \mathrm{E}-10$ \\
\hline $\mathrm{Cu}-67$ & 25 & $2.27 \mathrm{E}-08$ & $5.68 \mathrm{E}-07$ & $2.84 \mathrm{E}-10$ \\
\hline Gd-153 & 1 & $1.80 \mathrm{E}-04$ & $1.80 \mathrm{E}-04$ & $9.00 \mathrm{E}-08$ \\
\hline Ho-166 & 25 & $3.37 \mathrm{E}-07$ & $8.43 \mathrm{E}-06$ & $4.21 \mathrm{E}-09$ \\
\hline $1-125$ & 1 & $1.70 \mathrm{E}-02$ & $1.70 \mathrm{E}-02$ & $8.50 \mathrm{E}-06$ \\
\hline $\mathrm{I}-131$ & 10 & $1.51 E-05$ & $1.51 \mathrm{E}-04$ & $7.55 \mathrm{E}-08$ \\
\hline Ir-192 & 1 & $3.79 \mathrm{E}-06$ & $3.79 \mathrm{E}-06$ & $1.90 \mathrm{E}-09$ \\
\hline Lu-177 & 10 & $8.17 \mathrm{E}-08$ & $8.17 \mathrm{E}-07$ & $4.09 \mathrm{E}-10$ \\
\hline Mo-99 & 25 & $6.11 \mathrm{E}-05$ & $1.53 \mathrm{E}-03$ & $7.64 \mathrm{E}-07$ \\
\hline Os-194 & 1 & $2.08 \mathrm{E}-05$ & $2.08 \mathrm{E}-05$ & $1.04 \mathrm{E}-08$ \\
\hline P-32 & 5 & 4.39E-07 & $2.20 \mathrm{E}-06$ & 1.10E-09 \\
\hline P-33 & 3 & $4.06 \mathrm{E}-06$ & $1.02 \mathrm{E}-05$ & $5.08 \mathrm{E}-09$ \\
\hline Pd-103 & 5 & 4.42E-06 & $2.21 \mathrm{E}-05$ & $1.11 \mathrm{E}-08$ \\
\hline $\mathrm{Pt}-195 \mathrm{~m}$ & 5 & $2.89 \mathrm{E}-07$ & $1.45 \mathrm{E}-06$ & $7.23 \mathrm{E}-10$ \\
\hline $\operatorname{Re}-186$ & 10 & $4.88 \mathrm{E}-05$ & $4.88 \mathrm{E}-04$ & $2.44 \mathrm{E}-07$ \\
\hline Sc- 47 & 25 & $1.51 \mathrm{E}-07$ & $3.78 \mathrm{E}-06$ & $1.89 \mathrm{E}-09$ \\
\hline Se-75 & 1 & $9.86 \mathrm{E}-07$ & $9.86 \mathrm{E}-07$ & $4.93 \mathrm{E}-10$ \\
\hline Sm-145 & 1 & $6.13 \mathrm{E}-06$ & $6.13 \mathrm{E}-06$ & $3.07 \mathrm{E}-09$ \\
\hline Sm-153 & 25 & 3.60E-07 & $9.00 \mathrm{E}-06$ & $4.50 \mathrm{E}-09$ \\
\hline $\mathrm{Sn}-117 \mathrm{~m}$ & 5 & $5.79 \mathrm{E}-07$ & $2.90 \mathrm{E}-06$ & $1.45 \mathrm{E}-09$ \\
\hline
\end{tabular}


HNF-1844, Rev. 0

Table 19. Radiological Impacts due to Truck Transportation Impacts during Shipping Medical Isotopes from Chicago, Il. Airport to Amersham Mediphysics

\begin{tabular}{|l|c|c|c|c|}
\hline \multicolumn{1}{|c|}{ Isotope* } & $\begin{array}{c}\text { Estimated Number } \\
\text { of Annual } \\
\text { Shipments }\end{array}$ & $\begin{array}{c}\text { Radiological } \\
\text { Impacts per } \\
\text { Shipment } \\
\text { (person-rem/ } \\
\text { shipment) }\end{array}$ & $\begin{array}{c}\text { Anmual } \\
\text { Radiological } \\
\text { Impacts } \\
\text { (person-rem/year) }\end{array}$ & $\begin{array}{c}\text { Health Effects } \\
\text { (LCFs/year) }^{\left({ }^{()}\right.}\end{array}$ \\
\hline Sr-85 & 1 & $2.59 \mathrm{E}-06$ & $2.59 \mathrm{E}-06$ & $1.30 \mathrm{E}-09$ \\
\hline Sr-89 & 3 & $4.39 \mathrm{E}-06$ & $1.10 \mathrm{E}-05$ & $5.49 \mathrm{E}-09$ \\
\hline Th-228 & 1 & $1.28 \mathrm{E}-01$ & $1.28 \mathrm{E}-01$ & $6.40 \mathrm{E}-05$ \\
\hline Th-229 & 1 & See Th-228 & See Th-228 & See Th-228 \\
\hline W-188 & 3 & $1.35 \mathrm{E}-03$ & $1.35 \mathrm{E}-03$ & $6.75 \mathrm{E}-07$ \\
\hline Xe-127 & 1 & $5.94 \mathrm{E}-06$ & $1.49 \mathrm{E}-05$ & $7.43 \mathrm{E}-09$ \\
\hline Y-91 & 1 & $1.62 \mathrm{E}-06$ & $1.62 \mathrm{E}-06$ & $8.10 \mathrm{E}-10$ \\
\hline
\end{tabular}

(a) Calculated using the methodology prescribed in ICRP 60 . 
Table 20. Radiological Impacts due to Truck Transportation Impacts during Shipping Medical Isotopes from St. Louis, Mo. to Malinckrodt

\begin{tabular}{|c|c|c|c|c|}
\hline Isotope & $\begin{array}{c}\text { Estimated Number } \\
\text { of Annual } \\
\text { Shipments }\end{array}$ & $\begin{array}{l}\text { Radiological } \\
\text { Impacts per } \\
\text { Shipment } \\
\text { (person-rem/ } \\
\text { shipment) }\end{array}$ & $\begin{array}{c}\text { Annual } \\
\text { Radiological } \\
\text { Impacts } \\
\text { (person-rem/year) }\end{array}$ & $\begin{array}{l}\text { Health Effects } \\
\text { (LCFs/year) }^{(\mathrm{a})(\mathrm{b})}\end{array}$ \\
\hline Ac- 227 & 1 & $3.36 \mathrm{E}-01$ & $3.36 \mathrm{E}-01$ & $1.68 \mathrm{E}-04$ \\
\hline $\mathrm{Au}-198$ & 25 & $7.04 \mathrm{E}-07$ & $1.76 \mathrm{E}-05$ & $8.80 \mathrm{E}-09$ \\
\hline Cd-109 & 1 & $2.28 \mathrm{E}-04$ & $2.28 \mathrm{E}-04$ & $1.14 \mathrm{E}-07$ \\
\hline $\mathrm{Cu}-64$ & 25 & $1.01 \mathrm{E}-08$ & $2.53 \mathrm{E}-07$ & $1.26 \mathrm{E}-10$ \\
\hline $\mathrm{Cu}-67$ & 25 & $7.67 \mathrm{E}-09$ & 1.92E-07 & $<1 \mathrm{E}-10$ \\
\hline Gd-153 & 1 & $5.98 \mathrm{E}-05$ & $5.98 \mathrm{E}-05$ & $2.99 \mathrm{E}-08$ \\
\hline Ho-166 & 25 & $1.14 \mathrm{E}-07$ & $2.85 \mathrm{E}-06$ & $1.43 \mathrm{E}-09$ \\
\hline I- 125 & 1 & $3.92 \mathrm{E}-03$ & $3.92 \mathrm{E}-03$ & $1.96 \mathrm{E}-06$ \\
\hline I-131 & 10 & $5.04 \mathrm{E}-06$ & $5.04 \mathrm{E}-05$ & $2.52 \mathrm{E}-08$ \\
\hline Ir -192 & 1 & $1.27 \mathrm{E}-06$ & $1.27 \mathrm{E}-06$ & $6.35 \mathrm{E}-10$ \\
\hline Lu-177 & 10 & $2.74 \mathrm{E}-08$ & $2.74 \mathrm{E}-07$ & $1.37 \mathrm{E}-10$ \\
\hline Mo-99 & 25 & $2.05 \mathrm{E}-05$ & $5.13 \mathrm{E}-04$ & $2.56 \mathrm{E}-07$ \\
\hline Os-194 & 1 & $6.97 \mathrm{E}-06$ & $6.97 \mathrm{E}-06$ & $3.49 \mathrm{E}-09$ \\
\hline P-32 & 5 & $1.48 \mathrm{E}-07$ & $7.40 \mathrm{E}-07$ & $3.70 \mathrm{E}-10$ \\
\hline P-33 & 3 & $1.35 \mathrm{E}-06$ & $3.38 \mathrm{E}-06$ & $1.69 \mathrm{E}-09$ \\
\hline Pd-103 & 5 & $1.46 \mathrm{E}-06$ & $7.30 \mathrm{E}-06$ & $3.65 \mathrm{E}-09$ \\
\hline Pt-195m & 5 & $9.73 \mathrm{E}-08$ & 4.87E-07 & $2.43 \mathrm{E}-10$ \\
\hline $\operatorname{Re}-186$ & 10 & 1.64E-05 & $1.64 \mathrm{E}-04$ & $8.20 \mathrm{E}-08$ \\
\hline Sc-47 & 25 & $5.07 \mathrm{E}-08$ & $1.27 \mathrm{E}-06$ & $6.34 \mathrm{E}-10$ \\
\hline Se-75 & 1 & $3.30 \mathrm{E}-07$ & $3.30 \mathrm{E}-07$ & $1.65 \mathrm{E}-10$ \\
\hline Sm-145 & 1 & $2.05 \mathrm{E}-06$ & $2.05 \mathrm{E}-06$ & $1.03 \mathrm{E}-09$ \\
\hline Sm-153 & 25 & $1.21 \mathrm{E}-07$ & $3.03 \mathrm{E}-06$ & 1.51E-09 \\
\hline $\mathrm{Sn}-117 \mathrm{~m}$ & 5 & $1.94 \mathrm{E}-07$ & $9.70 \mathrm{E}-07$ & $4.85 \mathrm{E}-10$ \\
\hline
\end{tabular}


HNF-1844, Rev. 0

Table 20. Radiological Impacts due to Truck Transportation Impacts during Shipping Medical Isotopes from St. Louis, Mo. to Malinckrodt

\begin{tabular}{|l|c|c|c|c|}
\hline \multicolumn{1}{|c|}{ Isotope } & $\begin{array}{c}\text { Estimated Number } \\
\text { of Annual } \\
\text { Shipments }\end{array}$ & $\begin{array}{c}\text { Radiological } \\
\text { Impacts per } \\
\text { Shipment } \\
\text { (person-rem/ } \\
\text { shipment) }\end{array}$ & $\begin{array}{c}\text { Annual } \\
\text { Radiological } \\
\text { Impacts } \\
\text { (person-rem/year) }\end{array}$ & $\begin{array}{c}\text { Health Effects } \\
\text { (LCFs/year) }^{(2)(())}\end{array}$ \\
\hline Sr-85 & 1 & $8.66 \mathrm{E}-07$ & $8.66 \mathrm{E}-07$ & $4.33 \mathrm{E}-10$ \\
\hline Sr-89 & 3 & $1.48 \mathrm{E}-06$ & $3.70 \mathrm{E}-06$ & $1.85 \mathrm{E}-09$ \\
\hline Th-228 & 1 & $4.31 \mathrm{E}-02$ & $4.31 \mathrm{E}-02$ & $2.16 \mathrm{E}-05$ \\
\hline Th-229 & 1 & See Th-228 & See Th-228 & See Th-228 \\
\hline W-188 & 3 & $4.38 \mathrm{E}-04$ & $4.38 \mathrm{E}-04$ & $2.19 \mathrm{E}-07$ \\
\hline $\mathrm{Xe}-127$ & 1 & $1.98 \mathrm{E}-06$ & $4.95 \mathrm{E}-06$ & $2.48 \mathrm{E}-09$ \\
\hline Y-91 & 1 & $5.44 \mathrm{E}-07$ & $5.44 \mathrm{E}-07$ & $2.72 \mathrm{E}-10$ \\
\hline
\end{tabular}

(a) Calculated using the methodology prescribed in ICRP 60

(b) Accident impacts are less than $1 \mathrm{E}-10$ health effects; insignificant contributors to annual and life-cycle transportation impacts. 
5.1.1.2 Radiological Impacts due to Air Transportation Accidents. The per-shipment impacts from air transportation accidents are presented in Tables 21, 22, and 23. These tables present the results in units of person-rem/shipment, person-rem/year and latent health effects/year. The latent health effects per were calculated by multiplying the radiation exposures in person-rem by a conversion factor $\left(5 \times 10^{-04}\right.$ latent health effects per personrem) taken from ICRP 60.

Table 21. Impacts from Air Transportation Accidents for Shipments from Pasco, Wa to Boston, Ma.

\begin{tabular}{|c|c|c|c|c|}
\hline Isotope" & $\begin{array}{l}\text { Number of } \\
\text { Shipments per } \\
\text { Year }\end{array}$ & $\begin{array}{l}\text { Radiological } \\
\text { impacts per } \\
\text { shipment } \\
\text { (person-rem/ } \\
\text { shipment) }\end{array}$ & $\begin{array}{c}\text { Annual } \\
\text { Radiological } \\
\text { Impacts } \\
\text { (person-rem/year) }\end{array}$ & $\begin{array}{l}\text { Health Effects } \\
\text { (LCFs/year) }^{(\mathrm{a})(\mathrm{b})}\end{array}$ \\
\hline Ac-227 & 1 & $2.88 \mathrm{E}+01$ & $2.88 \mathrm{E}+01$ & $1.44 \mathrm{E}-02$ \\
\hline Au-198 & 25 & 3.37E-07 & $8.42 \mathrm{E}-06$ & $4.21 \mathrm{E}-09$ \\
\hline $\mathrm{Cd}-109$ & 1 & $1.08 \mathrm{E}-04$ & $1.08 \mathrm{E}-04$ & $5.38 \mathrm{E}-08$ \\
\hline $\mathrm{Cu}-64$ & 25 & $5.35 \mathrm{E}-09$ & $1.34 \mathrm{E}-07$ & $<1 \mathrm{E}-10$ \\
\hline $\mathrm{Cu}-67$ & 25 & $3.66 \mathrm{E}-09$ & $9.16 \mathrm{E}-08$ & $<1 \mathrm{E}-10$ \\
\hline Gd-153 & 1 & $2.81 \mathrm{E}-05$ & $2.81 \mathrm{E}-05$ & $1.40 \mathrm{E}-08$ \\
\hline Ho-166 & 25 & $5.44 \mathrm{E}-08$ & $1.36 \mathrm{E}-06$ & $6.79 \mathrm{E}-10$ \\
\hline I-125 & 1 & $1.88 \mathrm{E}-03$ & $1.88 \mathrm{E}-03$ & $9.38 \mathrm{E}-07$ \\
\hline I-131 & 10 & $8.98 \mathrm{E}-05$ & $8.98 \mathrm{E}-04$ & $4.49 \mathrm{E}-07$ \\
\hline Ir -192 & 1 & $6.00 \mathrm{E}-07$ & $6.00 \mathrm{E}-07$ & $3.00 \mathrm{E}-10$ \\
\hline Lu-177 & 10 & $1.30 \mathrm{E}-08$ & $1.30 \mathrm{E}-07$ & $<1 \mathrm{E}-10$ \\
\hline Mo-99 & 25 & $9.25 \mathrm{E}-06$ & $2.31 \mathrm{E}-04$ & $1.16 \mathrm{E}-07$ \\
\hline Os-194 & 1 & $3.31 \mathrm{E}-06$ & $3.31 \mathrm{E}-06$ & 1.65E-09 \\
\hline P-32 & 5 & $7.10 \mathrm{E}-08$ & $3.55 \mathrm{E}-07$ & $1.78 \mathrm{E}-10$ \\
\hline P-33 & 3 & $6.38 \mathrm{E}-07$ & $1.60 \mathrm{E}-06$ & $7.98 \mathrm{E}-10$ \\
\hline Pd-103 & 5 & $6.76 \mathrm{E}-07$ & $3.38 \mathrm{E}-06$ & $1.69 \mathrm{E}-09$ \\
\hline Pt-195m & 5 & $4.65 \mathrm{E}-08$ & $2.33 \mathrm{E}-07$ & $1.16 \mathrm{E}-10$ \\
\hline Re-186 & 10 & $7.78 \mathrm{E}-06$ & $7.78 \mathrm{E}-05$ & $3.89 \mathrm{E}-08$ \\
\hline
\end{tabular}


HNF-1844, Rev. 0

Table 21. Impacts from Air Transportation Accidents for Shipments from Pasco, Wa to Boston, Ma.

\begin{tabular}{|l|c|c|c|c|}
\hline \multicolumn{1}{|c|}{ Isotope* } & $\begin{array}{c}\text { Number of } \\
\text { Shipments per } \\
\text { Year }\end{array}$ & $\begin{array}{c}\text { Radiological } \\
\text { impacts per } \\
\text { shipment } \\
\text { (person-rem/ } \\
\text { shipment) }\end{array}$ & $\begin{array}{c}\text { Annual } \\
\text { Radiological } \\
\text { Impacts } \\
\text { (person-rem/year) }\end{array}$ & $\begin{array}{c}\text { Health Effects } \\
\text { (LCFs/year) }{ }^{(\mathrm{a})(\mathrm{b})}\end{array}$ \\
\hline Sc-47 & 25 & $2.42 \mathrm{E}-08$ & $6.06 \mathrm{E}-07$ & $3.03 \mathrm{E}-10$ \\
\hline Se-75 & 1 & $1.57 \mathrm{E}-07$ & $1.57 \mathrm{E}-07$ & $<1 \mathrm{E}-10$ \\
\hline Sm-145 & 1 & $9.69 \mathrm{E}-07$ & $9.69 \mathrm{E}-07$ & $4.84 \mathrm{E}-10$ \\
\hline Sm-153 & 25 & $5.79 \mathrm{E}-08$ & $1.45 \mathrm{E}-06$ & $7.24 \mathrm{E}-10$ \\
\hline Sn-117m & 1 & $9.17 \mathrm{E}-08$ & $4.59 \mathrm{E}-07$ & $2.29 \mathrm{E}-10$ \\
\hline Sr-85 & 3 & $4.09 \mathrm{E}-07$ & $4.09 \mathrm{E}-07$ & $2.05 \mathrm{E}-10$ \\
\hline Sr-89 & 1 & $7.09 \mathrm{E}-07$ & $1.77 \mathrm{E}-06$ & $8.86 \mathrm{E}-10$ \\
\hline Th-228 & 1 & $7.83 \mathrm{E}-01$ & $7.83 \mathrm{E}-01$ & $3.91 \mathrm{E}-04$ \\
\hline Th-229 & 1 & See Th-228 & See Th-228 & Sce Th-228 \\
\hline W-188 & 3 & $1.99 \mathrm{E}-04$ & $1.99 \mathrm{E}-04$ & $9.97 \mathrm{E}-08$ \\
\hline Xe-127 & 1 & $9.35 \mathrm{E}-07$ & $2.34 \mathrm{E}-06$ & $1.17 \mathrm{E}-09$ \\
\hline Y-91 & $2.60 \mathrm{E}-07$ & $2.60 \mathrm{E}-07$ & $1.30 \mathrm{E}-10$ \\
\hline
\end{tabular}

(a) Calculated using the methodology prescribed in ICRP 60.

(b) Accident impacts are less than $1 \mathrm{E}-10$ health effects; insignificant contributors to annual and life-cycle transportation impacts. 
HNF-1844, Rev. 0

Table 22. Impacts from Air Transportation Accidents for Shipments from Pasco, Wa to Chicago, Il.

\begin{tabular}{|c|c|c|c|c|}
\hline Isotope & $\begin{array}{c}\text { Number of } \\
\text { shipments per } \\
\text { year }\end{array}$ & $\begin{array}{l}\text { Radiological } \\
\text { Impacts per } \\
\text { Shipment } \\
\text { (person-rem/ } \\
\text { shipment) }\end{array}$ & $\begin{array}{c}\text { Annual } \\
\text { Radiological } \\
\text { Impacts } \\
\text { (person-rem/year) }\end{array}$ & $\begin{array}{l}\text { Health Effects } \\
\text { (LCFs/year) }^{(a)(b)}\end{array}$ \\
\hline Ac-227 & 1 & $1.95 \mathrm{E}+01$ & $1.95 \mathrm{E}+01$ & 9.77E-03 \\
\hline Au-198 & 25 & $2.28 \mathrm{E}-07$ & $5.70 \mathrm{E}-06$ & $2.85 \mathrm{E}-09$ \\
\hline $\mathrm{Cd}-109$ & 1 & $7.28 \mathrm{E}-05$ & $7.28 \mathrm{E}-05$ & $3.64 \mathrm{E}-08$ \\
\hline $\mathrm{Cu}-64$ & 25 & 3.62E-09 & $9.05 \mathrm{E}-08$ & $<1 E-10$ \\
\hline $\mathrm{Cu}-67$ & 25 & $2.48 \mathrm{E}-09$ & $6.20 \mathrm{E}-08$ & $<1 \mathrm{E}-10$ \\
\hline Gd-153 & 1 & $1.90 \mathrm{E}-05$ & $1.90 \mathrm{E}-05$ & $9.50 \mathrm{E}-09$ \\
\hline Ho-166 & 25 & $3.68 \mathrm{E}-08$ & $9.20 \mathrm{E}-07$ & $4.60 \mathrm{E}-10$ \\
\hline $\mathrm{I}-125$ & 1 & $1.27 \mathrm{E}-03$ & $1.27 \mathrm{E}-03$ & $6.35 \mathrm{E}-07$ \\
\hline $\mathrm{I}-131$ & 10 & $6.08 \mathrm{E}-05$ & $6.08 \mathrm{E}-04$ & $3.04 \mathrm{E}-07$ \\
\hline Ir-192 & 1 & $4.06 \mathrm{E}-07$ & $4.06 \mathrm{E}-07$ & $2.03 \mathrm{E}-10$ \\
\hline Lu-177 & 10 & $8.82 \mathrm{E}-09$ & $8.82 \mathrm{E}-08$ & $<1 \mathrm{E}-10$ \\
\hline Mo-99 & 25 & $6.26 \mathrm{E}-06$ & $1.57 \mathrm{E}-04$ & $7.83 \mathrm{E}-08$ \\
\hline Os-194 & 1 & $2.24 \mathrm{E}-06$ & $2.24 \mathrm{E}-06$ & $1.12 \mathrm{E}-09$ \\
\hline P-32 & 5 & $4.81 \mathrm{E}-08$ & $2.41 \mathrm{E}-07$ & $1.20 \mathrm{E}-10$ \\
\hline P-33 & 3 & 4.32E-07 & $1.08 \mathrm{E}-06$ & $5.40 \mathrm{E}-10$ \\
\hline Pd-103 & 5 & $4.58 \mathrm{E}-07$ & $2.29 \mathrm{E}-06$ & $1.15 \mathrm{E}-09$ \\
\hline Pt-195m & 5 & $3.15 \mathrm{E}-08$ & $1.58 \mathrm{E}-07$ & $<1 \mathrm{E}-10$ \\
\hline $\operatorname{Re}-186$ & 10 & $5.27 \mathrm{E}-06$ & $5.27 \mathrm{E}-05$ & $2.64 \mathrm{E}-08$ \\
\hline Sc-47 & 25 & $1.64 \mathrm{E}-08$ & 4.10E-07 & $2.05 \mathrm{E}-10$ \\
\hline $\mathrm{Se}-75$ & 1 & $1.06 \mathrm{E}-07$ & $1.06 \mathrm{E}-07$ & $<1 \mathrm{E}-10$ \\
\hline Sm-145 & 1 & $6.56 \mathrm{E}-07$ & $6.56 \mathrm{E}-07$ & $3.28 \mathrm{E}-10$ \\
\hline $\mathrm{Sm}-153$ & 25 & $3.92 \mathrm{E}-08$ & $9.80 \mathrm{E}-07$ & $4.90 \mathrm{E}-10$ \\
\hline Sn-117m & 5 & $6.21 \mathrm{E}-08$ & $3.11 \mathrm{E}-07$ & $1.55 \mathrm{E}-10$ \\
\hline $\mathrm{Sr}-85$ & 1 & $2.77 \mathrm{E}-07$ & $2.77 \mathrm{E}-07$ & $1.39 \mathrm{E}-10$ \\
\hline
\end{tabular}


HNF-1844, Rev. 0

Table 22. Impacts from Air Transportation Accidents for Shipments from Pasco, Wa to Chicago, Il.

\begin{tabular}{|l|c|c|c|c|}
\hline Sr-89 & 3 & $4.80 \mathrm{E}-07$ & $1.20 \mathrm{E}-06$ & $6.00 \mathrm{E}-10$ \\
\hline Th-228 & 1 & $5.30 \mathrm{E}-01$ & $5.30 \mathrm{E}-01$ & $2.65 \mathrm{E}-04$ \\
\hline Th-229 & 1 & See Th-228 & See Th-228 & See Th-228 \\
\hline W-188 & 1 & $1.35 \mathrm{E}-04$ & $1.35 \mathrm{E}-04$ & $6.75 \mathrm{E}-08$ \\
\hline Xe-127 & 3 & $6.33 \mathrm{E}-07$ & $1.58 \mathrm{E}-06$ & $7.91 \mathrm{E}-10$ \\
\hline Y-91 & 1 & $1.76 \mathrm{E}-07$ & $1.76 \mathrm{E}-07$ & $<1 \mathrm{E}-10$ \\
\hline
\end{tabular}

(a) Calculated using the methodology prescribed in ICRP 60.

(b) Accident impacts are less than 1E-10 health effects; insignificant contributors to annual and life-cycle transportation impacts. 
HNF-1844, Rev. 0

Table 23. Impacts from Air Transportation Accidents for Shipments from Pasco, Wa to St. Louis, Mo.

\begin{tabular}{|c|c|c|c|c|}
\hline Isotope & $\begin{array}{l}\text { Number of } \\
\text { Shipments per } \\
\text { Year }\end{array}$ & $\begin{array}{l}\text { Radiological } \\
\text { Impacts per } \\
\text { Shipment } \\
\text { (person-rem/ } \\
\text { shipment) }\end{array}$ & $\begin{array}{c}\text { Annual } \\
\text { Radiological } \\
\text { Impacts } \\
\text { (person-rem/year) }\end{array}$ & $\begin{array}{l}\text { Health Effects } \\
\text { (LCFs/year) }^{(\alpha) /(b)}\end{array}$ \\
\hline Ac- 227 & 1 & $1.84 \mathrm{E}+01$ & $1.84 \mathrm{E}+01$ & $9.21 \mathrm{E}-03$ \\
\hline Au-198 & 25 & $2.15 \mathrm{E}-07$ & $5.38 \mathrm{E}-06$ & $2.69 \mathrm{E}-09$ \\
\hline Cd-109 & 1 & $6.87 \mathrm{E}-05$ & $6.87 \mathrm{E}-05$ & $3.43 \mathrm{E}-08$ \\
\hline $\mathrm{Cu}-64$ & 25 & $3.41 \mathrm{E}-09$ & $8.53 E-08$ & $<1 \mathrm{E}-10$ \\
\hline $\mathrm{Cu}-67$ & 25 & $2.34 \mathrm{E}-09$ & $5.85 \mathrm{E}-08$ & $<1 \mathrm{E}-10$ \\
\hline Gd-153 & 1 & $1.79 \mathrm{E}-05$ & $1.79 \mathrm{E}-05$ & $8.96 \mathrm{E}-09$ \\
\hline Ho-166 & 25 & $3.47 \mathrm{E}-08$ & $8.68 \mathrm{E}-07$ & $4.34 \mathrm{E}-10$ \\
\hline $\mathrm{I}-125$ & I & $1.20 \mathrm{E}-03$ & $1.20 \mathrm{E}-03$ & $5.99 \mathrm{E}-07$ \\
\hline I-131 & 10 & $5.73 \mathrm{E}-05$ & $5.73 \mathrm{E}-04$ & $2.87 \mathrm{E}-07$ \\
\hline Ir-192 & 1 & $3.83 \mathrm{E}-07$ & $3.83 \mathrm{E}-07$ & $1.91 \mathrm{E}-10$ \\
\hline $\mathrm{Lu}-177$ & 10 & 8.32E-09 & 8.32E-08 & $<1 \mathrm{E}-10$ \\
\hline Mo-99 & 25 & $5.90 \mathrm{E}-06$ & $1.48 \mathrm{E}-04$ & $7.38 \mathrm{E}-08$ \\
\hline Os-194 & I & $2.11 \mathrm{E}-06$ & $2.11 \mathrm{E}-06$ & $1.06 \mathrm{E}-09$ \\
\hline P-32 & 5 & $4.54 \mathrm{E}-08$ & $2.27 \mathrm{E}-07$ & $1.13 \mathrm{E}-10$ \\
\hline P.33 & 3 & $4.07 \mathrm{E}-07$ & $1.02 \mathrm{E}-06$ & $5.09 \mathrm{E}-10$ \\
\hline Pd-103 & 5 & $4.32 \mathrm{E}-07$ & $2.16 \mathrm{E}-06$ & $1.08 \mathrm{E}-09$ \\
\hline Pt-195m & 5 & $2.97 \mathrm{E}-08$ & $1.49 \mathrm{E}-07$ & $<1 \mathrm{E}-10$ \\
\hline $\operatorname{Re}-186$ & 10 & $4.97 \mathrm{E}-06$ & $4.97 \mathrm{E}-05$ & $2.48 \mathrm{E}-08$ \\
\hline Sc- 47 & 25 & $1.55 \mathrm{E}-08$ & $3.87 \mathrm{E}-07$ & $1.93 \mathrm{E}-10$ \\
\hline $\mathrm{Se}-75$ & 1 & $1.00 \mathrm{E}-07$ & $1.00 \mathrm{E}-07$ & $<1 \mathrm{E}-10$ \\
\hline Sm-145 & 1 & $6.19 \mathrm{E}-07$ & $6.19 \mathrm{E}-07$ & $3.09 \mathrm{E}-10$ \\
\hline Sm-153 & 25 & 3.70E-08 & $9.24 \mathrm{E}-07$ & $4.62 \mathrm{E}-10$ \\
\hline $\mathrm{Sn}-117 \mathrm{~m}$ & 5 & $5.86 \mathrm{E}-08$ & $2.93 \mathrm{E}-07$ & $1.46 \mathrm{E}-10$ \\
\hline Sr-85 & 1 & $2.61 \mathrm{E}-07$ & $2.61 \mathrm{E}-07$ & $1.31 \mathrm{E}-10$ \\
\hline
\end{tabular}


Table 23. Impacts from Air Transportation Accidents for Shipments from Pasco, Wa to St. Louis, Mo.

\begin{tabular}{|l|c|c|c|c|}
\hline \multicolumn{1}{|c|}{ Isotope } & $\begin{array}{c}\text { Number of } \\
\text { Shipments per } \\
\text { Year }\end{array}$ & $\begin{array}{c}\text { Radiological } \\
\text { Impacts per } \\
\text { Shipment } \\
\text { (person-rem/ } \\
\text { shipment) }\end{array}$ & $\begin{array}{c}\text { Annual } \\
\text { Radiological } \\
\text { Impacts } \\
\text { (person-rem/year) }\end{array}$ & $\begin{array}{c}\text { Health Effects } \\
\text { (LCFs/year) }\end{array}$ \\
\hline Sr-8((b)
\end{tabular}

(a) Calculated using the methodology prescribed in ICRP 60.

(b) Accident impacts are less than $1 \mathrm{E}-10$ health effects; insignificant contributors to annual and life-cycle transportation impacts.

5.1.1.3 Radiological Impacts to Maximum-Exposed Individuals. Radiological doses were calculated for maximum-exposed individuals for a severe transportation accident that may occur at or near the 325 Building. This includes a maximum onsite individual and a maximum offsite individual located at the site boundary. For this bounding analysis it was assumed that all of the maximum individuals were located to the east-south-east of the release which, in general, is the direction in which maximum consequences are obtained.

Credible accidents are typically defined as those having a frequency greater than or equal to once per million years. This analysis evaluated the maximum individual doses that would result from a release of the worst-case (highest dose producing) isotope shipment. The worst case isotope shipment, based on the results of the RADTRAN accident risk calculations (see Tables 17, 18, and 19), was determined to be Ac-227 (including Th-227, Th-228, and Th229).

Radiological accident impacts to the maximum offsite and onsite individual and the maximum individual were calculated using GENII (Napier et al. 1988). The results of the radiological dose calculations for the maximum individuals are presented in Table 24 . These values can be used to assess the maximum individual exposures from the maximum credible transportation accident. 
Table 24. Dose to Maximally Exposed Individuals

\begin{tabular}{|c|c|c|}
\hline $\begin{array}{c}\text { Maximum } \\
\text { Individual }\end{array}$ & $\begin{array}{c}\text { Distance from } \\
\text { Release }^{(\text {a) }}\end{array}$ & $\begin{array}{c}\text { Total Effective } \\
\text { Dose Equivalent } \\
\text { (rem) }\end{array}$ \\
\hline Onsite & $100 \mathrm{~m}$ & 1184 \\
\hline Offsite & $580 \mathrm{~m}$ & 138 \\
\hline
\end{tabular}

(a) Distances to maximally exposed individuals taken from the 325 Building Safety Analysis Report (PNNL 1996).

5.1.1.4 Summary of Transportation Accident Radiological Impacts. The transportation accident radiological impacts for the production, separation, and distribution of an isotope is the summation of the truck and air transportation accident impacts. The results are presented in Table 25.

Table 25 Summary of Transportation Accident Impacts ${ }^{(2)(b)}$

\begin{tabular}{|c|c|c|c|c|}
\hline \multirow[t]{3}{*}{ Isotope } & \multirow[t]{3}{*}{$\begin{array}{l}\text { Number of Annual } \\
\text { Shipments }\end{array}$} & \multicolumn{3}{|c|}{$\begin{array}{l}\text { Summary of Impacts from Irradiated Target and Isotope } \\
\text { Product Shipments to Pharmaceutical Distributors }\end{array}$} \\
\hline & & DuPont & Amersham & Malinckrodt \\
\hline & & $\begin{array}{l}\text { Health Effects } \\
\text { (LCFs/year) }^{(c)}\end{array}$ & $\begin{array}{l}\text { Health Effects } \\
\text { (LCFs/year) }^{(\mathrm{c})}\end{array}$ & $\begin{array}{l}\text { Health Effects } \\
\text { (LCFs/year) }^{(\mathrm{c})}\end{array}$ \\
\hline$A c-227^{(d)}$ & 1 & $1.5 \mathrm{E}-02$ & $1.0 \mathrm{E}-02$ & $9.4 \mathrm{E}-03$ \\
\hline $\mathrm{Au}-198$ & 25 & $2.2 \mathrm{E}-08$ & $3.2 \mathrm{E}-08$ & $1.4 \mathrm{E}-08$ \\
\hline Cd-109 & 1 & $2.8 \mathrm{E}-07$ & $4.1 \mathrm{E}-07$ & $1.8 \mathrm{E}-07$ \\
\hline $\mathrm{Cu}-64$ & 25 & $3.2 \mathrm{E}-10$ & $4.6 \mathrm{E}-10$ & $2.1 \mathrm{E}-10$ \\
\hline $\mathrm{Cu}-67$ & 25 & $2.4 \mathrm{E}-10$ & $3.4 \mathrm{E}-10$ & $1.5 \mathrm{E}-10$ \\
\hline Gd-153 & 1 & $7.3 \mathrm{E}-08$ & $1.1 \mathrm{E}-07$ & $4.8 \mathrm{E}-08$ \\
\hline Ho-166 & 25 & $1.1 \mathrm{E}-04$ & $5.1 \mathrm{E}-09$ & $2.3 \mathrm{E}-09$ \\
\hline I-125 & 1 & $4.8 \mathrm{E}-06$ & $9.7 \mathrm{E}-06$ & $3.1 \mathrm{E}-06$ \\
\hline $\mathrm{I}-131$ & 10 & $5.0 \mathrm{E}-07$ & $3.9 \mathrm{E}-07$ & $3.2 \mathrm{E}-07$ \\
\hline Ir-192 & 1 & $1.5 \mathrm{E}-09$ & 2.3E-09 & $1.0 \mathrm{E}-09$ \\
\hline Lu-177 & 10 & $3.4 \mathrm{E}-10$ & $4.9 \mathrm{E}-10$ & $2.2 \mathrm{E}-10$ \\
\hline
\end{tabular}


Table 25 Summary of Transportation Accident Impacts ${ }^{(2)(b)}$

\begin{tabular}{|c|c|c|c|c|}
\hline \multirow[t]{3}{*}{ Isotope } & \multirow[t]{3}{*}{$\begin{array}{l}\text { Number of Annual } \\
\text { Shipments }\end{array}$} & \multicolumn{3}{|c|}{$\begin{array}{l}\text { Summary of Impacts from Irradiated Target and Isotope } \\
\text { Product Shipments to Pharmaceutical Distributors }\end{array}$} \\
\hline & & DuPont & Amersham & Malinckrodt \\
\hline & & $\begin{array}{l}\text { Health Effects } \\
\text { (LCFs/year) }^{(c)}\end{array}$ & $\begin{array}{l}\text { Health Effects } \\
\text { (LCFs/year) }^{(\mathrm{c})}\end{array}$ & $\begin{array}{l}\text { Health Effects } \\
\text { (LCFs/year) }^{(c)}\end{array}$ \\
\hline Mo-99 & 25 & $6.2 \mathrm{E}-07$ & $9.2 \mathrm{E}-07$ & $4.1 \mathrm{E}-07$ \\
\hline Os-194 & 1 & $8.5 \mathrm{E}-09$ & $1.3 \mathrm{E}-08$ & $5.6 \mathrm{E}-09$ \\
\hline P-32 & 5 & $9.1 \mathrm{E}-10$ & $1.3 \mathrm{E}-09$ & $5.9 \mathrm{E}-10$ \\
\hline P-33 & 3 & $4.1 \mathrm{E}-09$ & $6.1 \mathrm{E}-09$ & $2.7 \mathrm{E}-09$ \\
\hline Pd-103 & 5 & $8.8 \mathrm{E}-09$ & $1.3 \mathrm{E}-08$ & $5.8 \mathrm{E}-09$ \\
\hline Pt-195m & 5 & $6.0 \mathrm{E}-10$ & $8.7 \mathrm{E}-10$ & $3.9 \mathrm{E}-10$ \\
\hline $\operatorname{Re}-186$ & 10 & $2.0 \mathrm{E}-07$ & $2.9 \mathrm{E}-07$ & $1.3 \mathrm{E}-07$ \\
\hline Sc-47 & 25 & $1.6 \mathrm{E}-09$ & $2.3 \mathrm{E}-09$ & $1.0 \mathrm{E}-09$ \\
\hline Se-75 & 1 & $4.0 \mathrm{E}-10$ & $6.0 \mathrm{E}-10$ & $2.6 \mathrm{E}-10$ \\
\hline Sm-145 & 1 & $2.5 \mathrm{E}-09$ & $3.7 \mathrm{E}-09$ & $1.6 \mathrm{E}-09$ \\
\hline $\mathrm{Sm}-153$ & 25 & $3.7 \mathrm{E}-09$ & $5.4 \mathrm{E}-09$ & $2.4 \mathrm{E}-09$ \\
\hline Sn-117m & 5 & $1.2 \mathrm{E}-09$ & $1.7 \mathrm{E}-09$ & $7.8 \mathrm{E}-10$ \\
\hline Sr-85 & 1 & $8.5 \mathrm{E}-10$ & $1.6 \mathrm{E}-09$ & $6.9 \mathrm{E}-10$ \\
\hline Sr-89 & 3 & $3.7 \mathrm{E}-09$ & $6.6 \mathrm{E}-09$ & $3.0 \mathrm{E}-09$ \\
\hline Th-228 & 1 & $4.3 \mathrm{E}-04$ & $3.4 \mathrm{E}-04$ & $2.8 \mathrm{E}-04$ \\
\hline Th-229 & 1 & See Th-228 & See Th-228 & See Th-228 \\
\hline W-188 & 1 & $5.2 \mathrm{E}-07$ & $8.1 \mathrm{E}-07$ & $3.5 \mathrm{E}-07$ \\
\hline $\mathrm{Xe}-127$ & 3 & $6.0 \mathrm{E}-09$ & $9.0 \mathrm{E}-09$ & $4.0 \mathrm{E}-09$ \\
\hline$Y-91$ & 1 & $5.4 \mathrm{E}-10$ & $9.8 \mathrm{E}-10$ & $4.4 \mathrm{E}-10$ \\
\hline
\end{tabular}

(a) See Tables 16 through 23 for radiological impacts.

(b) Transportation accident impacts for liquid or solid waste are less than 7.0E-08 LCFs/year (see Table 16)

(c) Calculated using the methodology prescribed in ICRP 60 .

(d) Includes impacts associated with shipments of Ra-226 targets from PNNL to FFTF. 
5.1.1.5 Non-Radiological Impacts due to Transportation Accidents. This section describes the analyses of impacts to the public and Hanford Site workers from nonradiological accidents.

The non-radiological impacts associated with the transportation of the isotope target material, irradiated targets, and separated isotopes are assumed to be comparable to the impacts associated with general transportation activities in the United States. The fatalities are due to vehicular impacts with solid objects, rollovers, or collisions. Results are obtained for each alternative by multiplying the unit risk factors by the appropriate total shipping distances for each alternative. The results of this analysis are shown in Table 26 for all materials shipped and destination.

Table 26. Nonradiological Impacts due to Transportation Accidents

\begin{tabular}{|c|c|}
\hline Transportation segment & $\begin{array}{c}\text { Estimated fatalities/ } \\
\text { year }\end{array}$ \\
\hline Target material from ORNL to the 300 Area $^{(a)(b)}$ & $1.8 \mathrm{E}-03$ \\
\hline Unirradiated targets from the 300 Area to the FFTF(c) & 3.6E-04 \\
\hline Irradiated targets from FFTF to 325 Building $^{(c)}$ & $3.6 \mathrm{E}-04$ \\
\hline Isotope product from 325 Building to Pasco Airport ${ }^{(\mathrm{c})}$ & $2.2 \mathrm{E}-04$ \\
\hline $\begin{array}{l}\text { Isotope products from destination Airport to } \\
\text { Distributor (maximum consequence) }{ }^{\text {(a)(c)(d) }}\end{array}$ & 3.2E-04 \\
\hline Solid and Liquid waste from 300 Area to 200 East Area & $1.7 \mathrm{E}-04$ \\
\hline Total & 3.2E-03 \\
\hline
\end{tabular}

(a) Calculated impacts are for one way distances. Drivers are assumed to return to ORNL area with non-related cargo. Other legs are for round-trip shipments, including loaded shipments and empty return shipments.

(b) Annual target material demand for each isotope is shipped on one truck, 29 shipments per year (e.g., annual requirements for $25 \mathrm{Sm}-153$ targets are shipped on the same truck).

(c) 246 shipments per year based on the number of irradiation cycles

(d) Shipments from Boston Airport to Du-Pont (2.9E-04 fatalities)

Shipments from Chicago Airport to Amersham (3.2E-04 fatalities)

Shipments from St. Louis Airport to Malinckrodt (1.0E-04 fatalities) 
HNF-1844, Rev. 0

\subsection{RADIOLOGICAL AND NONRADIOLOGICAL IMPACTS DUE TO ROUTINE OR INCIDENT-FREE TRANSPORTATION ACTIVITIES}

\subsubsection{Radiological Impacts Due to Routine or Incident-free Transportation Activities}

The radiological doses to the truck crew, air crew, onsite worker, and the public due to transportation activities were calculated using RADTRAN 4 (see Sections 1 and 4). RADTRAN 4 uses a combination of meteorological, demographic, health physics, transportation, packaging, and material factors to analyze the radiological exposures from incident-free transport activities. The calculated dose to the truck and air crew, and the public were calculated for one shipment of each isotope.

\subsubsection{Radiological Impacts Due to Routine or Incident-free Truck Transportation} Activities. The potential routine radiological impacts were estimated for truck shipments of irradiated target materials from the 325 Building to FFTF (i.e., Ra-226), irradiated targets from FFTF to the 325 Building, and separated isotopes from the 325 Building to the distributors. There are no radiological impacts associated with transport of the target materials from ORNL to PNNL. It is also assumed that there are no radiological impacts associated with the return shipment of the empty shipping cask from the 325 Building to FFTF.

The potential radiological impacts involve in-transit doses to the public or where appropriate Hanford Site workers from radiation emitted from the shipping cask and doses to the transport workers in the vicinity of the shipment during cask handling activities, e.g., loading or unloading the cask on or off the truck trailer. In-transit doses were estimated for the truck drivers, as well as the general public, including persons at truck stops, persons living or working adjacent to the transport route, and nearby travelers (moving in the same and opposite directions). Tables 27 through 31 provides summaries of the annual radiological impacts for shipments to each pharmaceutical distributor. Table 27 presents the results for the irradiated target shipments from FFTF to the 325 Building and shipments from the 325 Building to FFTF (Ra-226 target) and the waste handling facilities, Table 28 for truck shipments from the 325 Building to the Tri-Cities Airport, and Tables 29, 30, and 31 provides the results for the truck shipments from the destination airport to the pharmaceutical distributors. 
HNF-1844, Rev. 0

Table 27. Routine Radiological Impacts for Truck Shipments of Irradiated Targets from FFTF to the $\mathbf{3 2 5}$ Building

\begin{tabular}{|c|c|c|c|c|c|c|c|}
\hline \multirow[t]{2}{*}{$\begin{array}{l}\text { Isotope/ } \\
\text { Material }\end{array}$} & \multirow{2}{*}{$\begin{array}{l}\text { Estimated } \\
\text { Number } \\
\text { Annual } \\
\text { Shipments }\end{array}$} & \multicolumn{2}{|c|}{$\begin{array}{l}\text { Radiological Impacts } \\
\text { per Shipment }\end{array}$} & \multicolumn{2}{|c|}{$\begin{array}{l}\text { Annual Radiological } \\
\text { Impacts }\end{array}$} & \multicolumn{2}{|c|}{ Annual Health Effects } \\
\hline & & $\begin{array}{c}\text { Crew } \\
\text { (person- } \\
\text { rem/ } \\
\text { shipment) }\end{array}$ & $\begin{array}{l}\text { Public } \\
\text { (person- } \\
\text { rem/ } \\
\text { shipment) }\end{array}$ & $\begin{array}{c}\text { Crew } \\
\text { (person- } \\
\text { rem/ year) }\end{array}$ & $\begin{array}{c}\text { Public } \\
\text { (person- } \\
\text { rem/ year) }\end{array}$ & 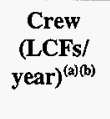 & $\begin{array}{c}\text { Public } \\
(\text { LCFs/ } \\
\text { year) }^{(\mathrm{a})(\mathrm{b})}\end{array}$ \\
\hline \multicolumn{8}{|c|}{ Shipments of Irradiated Targets from FFTF to PNNL } \\
\hline Ac-227 & 1 & $1.63 \mathrm{E}-06$ & $7.85 \mathrm{E}-08$ & $1.63 \mathrm{E}-06$ & $7.85 \mathrm{E}-08$ & $6.51 \mathrm{E}-10$ & $<1 \mathrm{E}-10$ \\
\hline $\mathrm{Au}-198$ & 25 & $1.63 \mathrm{E}-06$ & $7.85 \mathrm{E}-08$ & 4.07E-05 & $1.96 \mathrm{E}-06$ & $1.63 \mathrm{E}-08$ & $9.82 \mathrm{E}-10$ \\
\hline Cd-109 & 1 & $1.90 \mathrm{E}-06$ & $9.19 \mathrm{E}-08$ & $1.90 \mathrm{E}-06$ & $9.19 \mathrm{E}-08$ & $7.62 \mathrm{E}-10$ & $<1 E-10$ \\
\hline $\mathrm{Cu}-64$ & 25 & $2.51 \mathrm{E}-06$ & $1.21 \mathrm{E}-07$ & $6.27 \mathrm{E}-05$ & $3.02 \mathrm{E}-06$ & $2.51 \mathrm{E}-08$ & $1.51 \mathrm{E}-09$ \\
\hline $\mathrm{Cu}-67$ & 25 & $2.51 \mathrm{E}-06$ & $1.21 \mathrm{E}-07$ & $6.27 \mathrm{E}-05$ & $3.02 \mathrm{E}-06$ & $2.51 \mathrm{E}-08$ & $1.51 \mathrm{E}-09$ \\
\hline Gd-153 & 1 & $1.28 \mathrm{E}-04$ & $6.19 \mathrm{E}-06$ & $1.28 \mathrm{E}-04$ & $6.19 \mathrm{E}-06$ & $5.13 \mathrm{E}-08$ & $3.09 \mathrm{E}-09$ \\
\hline Ho-166 & 25 & $1.64 \mathrm{E}-06$ & $7.90 \mathrm{E}-08$ & $4.10 \mathrm{E}-05$ & $1.98 \mathrm{E}-06$ & 1.64E-08 & $9.88 \mathrm{E}-10$ \\
\hline I- 125 & 1 & $1.69 \mathrm{E}-06$ & $8.14 \mathrm{E}-08$ & $1.69 \mathrm{E}-06$ & $8.14 \mathrm{E}-08$ & $6.75 \mathrm{E}-10$ & $<1 \mathrm{E}-10$ \\
\hline$I-131$ & 10 & $1.72 \mathrm{E}-06$ & $8.28 \mathrm{E}-08$ & $1.72 \mathrm{E}-05$ & $8.28 \mathrm{E}-07$ & $6.87 \mathrm{E}-09$ & $4.14 \mathrm{E}-10$ \\
\hline Ir-192. & 1 & $1.69 \mathrm{E}-06$ & $8.14 \mathrm{E}-08$ & $1.69 \mathrm{E}-06$ & $8.14 \mathrm{E}-08$ & $6.75 \mathrm{E}-10$ & $<1 \mathrm{E}-10$ \\
\hline $\mathrm{Lu}-177$ & 10 & $1.63 \mathrm{E}-06$ & $7.85 \mathrm{E}-08$ & $1.63 \mathrm{E}-05$ & $7.85 \mathrm{E}-07$ & $6.51 \mathrm{E}-09$ & $3.93 \mathrm{E}-10$ \\
\hline Mo-99 & 25 & $1.66 \mathrm{E}-06$ & $8.00 \mathrm{E}-08$ & $4.15 \mathrm{E}-05$ & $2.00 \mathrm{E}-06$ & $1.66 \mathrm{E}-08$ & $1.00 \mathrm{E}-09$ \\
\hline Os-194 & 1 & $1.63 \mathrm{E}-06$ & $7.85 \mathrm{E}-08$ & $1.63 \mathrm{E}-06$ & $7.85 \mathrm{E}-08$ & $6.51 \mathrm{E}-10$ & $<1 \mathrm{E}-10$ \\
\hline P-32 & 5 & $2.51 \mathrm{E}-06$ & $1.21 \mathrm{E}-07$ & $1.25 \mathrm{E}-05$ & $6.05 \mathrm{E}-07$ & $5.01 \mathrm{E}-09$ & $3.02 \mathrm{E}-10$ \\
\hline P-33 & 3 & $2.51 \mathrm{E}-06$ & $1.21 \mathrm{E}-07$ & $6.27 \mathrm{E}-06$ & $3.02 \mathrm{E}-07$ & $2.51 \mathrm{E}-09$ & $1.51 \mathrm{E}-10$ \\
\hline Pd-103 & 5 & $2.51 \mathrm{E}-06$ & $1.21 \mathrm{E}-07$ & $1.25 \mathrm{E}-05$ & $6.05 \mathrm{E}-07$ & $5.01 \mathrm{E}-09$ & $3.02 \mathrm{E}-10$ \\
\hline Pt-195m & 5 & $1.63 \mathrm{E}-06$ & $7.85 \mathrm{E}-08$ & $8.14 \mathrm{E}-06$ & 3.93E-07 & $3.26 \mathrm{E}-09$ & $1.96 \mathrm{E}-10$ \\
\hline Re-186 & 10 & $1.63 \mathrm{E}-06$ & $7.85 \mathrm{E}-08$ & $1.63 \mathrm{E}-05$ & $7.85 \mathrm{E}-07$ & $6.51 \mathrm{E}-09$ & $3.93 \mathrm{E}-10$ \\
\hline Sc-47 & 25 & $2.51 \mathrm{E}-06$ & $1.21 \mathrm{E}-07$ & $6.27 \mathrm{E}-05$ & $3.02 \mathrm{E}-06$ & $2.51 \mathrm{E}-08$ & $1.51 \mathrm{E}-09$ \\
\hline Se-75 & 1 & $1.63 \mathrm{E}-06$ & $7.85 \mathrm{E}-08$ & $1.63 \mathrm{E}-06$ & $7.85 \mathrm{E}-08$ & $6.51 \mathrm{E}-10$ & $<1 \mathrm{E}-10$ \\
\hline Sm-145 & 1 & $1.63 \mathrm{E}-06$ & $7.85 \mathrm{E}-08$ & 1.63E-06 & $7.85 \mathrm{E}-08$ & $6.51 \mathrm{E}-10$ & $<1 \mathrm{E}-10$ \\
\hline
\end{tabular}


HNF-1844, Rev. 0

Table 27. Routine Radiological Impacts for Truck Shipments of Irradiated Targets from FFTF to the 325 Building

\begin{tabular}{|c|c|c|c|c|c|c|c|}
\hline \multirow[t]{2}{*}{$\begin{array}{l}\text { Isotope/ } \\
\text { Material }\end{array}$} & \multirow{2}{*}{$\begin{array}{c}\text { Estimated } \\
\text { Number } \\
\text { Annual } \\
\text { Shipments }\end{array}$} & \multicolumn{2}{|c|}{$\begin{array}{l}\text { Radiological Impacts } \\
\text { per Shipment }\end{array}$} & \multicolumn{2}{|c|}{$\begin{array}{l}\text { Annual Radiological } \\
\text { Impacts }\end{array}$} & \multicolumn{2}{|c|}{ Annual Health Effects } \\
\hline & & $\begin{array}{c}\text { Crew } \\
\text { (person- } \\
\text { rem/ } \\
\text { shipment) }\end{array}$ & $\begin{array}{c}\text { Public } \\
\text { (person- } \\
\text { rem/ } \\
\text { shipment) }\end{array}$ & $\begin{array}{c}\text { Crew } \\
\text { (person- } \\
\text { rem/ year) }\end{array}$ & $\begin{array}{c}\text { Public } \\
\text { (person- } \\
\text { rem/ year) }\end{array}$ & 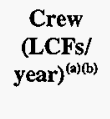 & 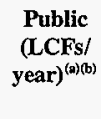 \\
\hline \multicolumn{8}{|c|}{ Shipments of Irradiated Targets from FFTF to PNNL } \\
\hline Sm-153 & 25 & $1.63 \mathrm{E}-06$ & $7.85 \mathrm{E}-08$ & $4.07 \mathrm{E}-05$ & $1.96 \mathrm{E}-06$ & $1.63 \mathrm{E}-08$ & $9.82 \mathrm{E}-10$ \\
\hline Sn-117m & 5 & $2.51 \mathrm{E}-06$ & $1.21 \mathrm{E}-07$ & $1.25 \mathrm{E}-05$ & $6.05 \mathrm{E}-07$ & $5.01 \mathrm{E}-09$ & $3.02 \mathrm{E}-10$ \\
\hline Sr-85 & 1 & $2.51 \mathrm{E}-06$ & $1.21 \mathrm{E}-07$ & $2.51 \mathrm{E}-06$ & $1.21 \mathrm{E}-07$ & $1.00 \mathrm{E}-09$ & $<1 \mathrm{E}-10$ \\
\hline Sr-89 & 3 & $2.51 \mathrm{E}-06$ & $1.21 \mathrm{E}-07$ & $6.27 \mathrm{E}-06$ & $3.02 \mathrm{E}-07$ & $2.51 \mathrm{E}-09$ & $1.51 \mathrm{E}-10$ \\
\hline Th-228 & 1 & $\begin{array}{c}\text { See } \\
\mathrm{AC}-227\end{array}$ & $\begin{array}{c}\text { See } \\
\mathrm{AC}-227\end{array}$ & $\begin{array}{c}\text { See } \\
\text { AC-227 }\end{array}$ & $\begin{array}{c}\text { See } \\
\mathrm{AC}-227\end{array}$ & $\begin{array}{c}\text { See } \\
\mathrm{AC}-227\end{array}$ & $\begin{array}{c}\text { See } \\
\mathrm{AC}-227\end{array}$ \\
\hline Th-229 & 1 & $\begin{array}{c}\text { See } \\
\mathrm{AC}-227\end{array}$ & $\begin{array}{c}\text { See } \\
\mathrm{AC}-227\end{array}$ & $\begin{array}{c}\text { See } \\
\mathrm{AC}-227\end{array}$ & $\begin{array}{c}\text { See } \\
\mathrm{AC}-227\end{array}$ & $\begin{array}{c}\text { See } \\
\mathrm{AC}-227\end{array}$ & $\begin{array}{c}\text { See } \\
\mathrm{AC}-227\end{array}$ \\
\hline W-188 & 1 & $1.72 \mathrm{E}-06$ & $8.28 \mathrm{E}-08$ & $1.72 \mathrm{E}-06$ & $8.28 \mathrm{E}-08$ & $6.87 \mathrm{E}-10$ & $<1 \mathrm{E}-10$ \\
\hline $\mathrm{Xe}-127$ & 3 & $2.51 \mathrm{E}-06$ & $1.21 \mathrm{E}-07$ & $6.27 \mathrm{E}-06$ & $3.02 \mathrm{E}-07$ & $2.51 \mathrm{E}-09$ & $1.51 \mathrm{E}-10$ \\
\hline$Y-91$ & 1 & $2.51 \mathrm{E}-06$ & $1.21 \mathrm{E}-07$ & $2.51 \mathrm{E}-06$ & $1.21 \mathrm{E}-07$ & $1.00 \mathrm{E}-09$ & $<1 \mathrm{E}-10$ \\
\hline \multicolumn{8}{|c|}{ Shipments from PNNL to FFTF and Waste Handling Facilities } \\
\hline $\begin{array}{l}\text { Ra-226 } \\
\text { target to } \\
\text { FFTF }\end{array}$ & 1 & $5.71 \mathrm{E}-22$ & $2.76 \mathrm{E}-23$ & $5.71 \mathrm{E}-22$ & $2.76 \mathrm{E}-23$ & $<1 \mathrm{E}-10$ & $<1 \mathrm{E}-10$ \\
\hline $\begin{array}{l}\text { Liquid } \\
\text { Waste to } \\
200 \text { East } \\
\text { Area }\end{array}$ & 2 & $2.58 \mathrm{E}-04$ & $5.57 \mathrm{E}-06$ & $5.16 \mathrm{E}-04$ & $1.11 \mathrm{E}-05$ & $2.06 \mathrm{E}-07$ & $5.57 \mathrm{E}-09$ \\
\hline $\begin{array}{l}\text { Solid } \\
\text { Waste to } \\
200 \text { West } \\
\text { Area }\end{array}$ & 35 & $3.22 \mathrm{E}-04$ & $6.95 \mathrm{E}-06$ & $1.13 \mathrm{E}-02$ & $2.43 \mathrm{E}-04$ & $4.51 \mathrm{E}-06$ & $1.22 \mathrm{E}-07$ \\
\hline
\end{tabular}

(a) Calculated using the methodology prescribed in ICRP 60

(b) Accident impacts are less than $1 \mathrm{E}-10$ health effects; insignificant contributors to annual and life-cycle transportation impacts 
HNF-1844, Rev. 0

Table 28. Routine Radiological Impacts for Truck Shipments of Separated Isotopes from the 325 Building to Pasco Airport

\begin{tabular}{|c|c|c|c|c|c|c|c|}
\hline \multirow[t]{2}{*}{ Isotope* } & \multirow{2}{*}{$\begin{array}{l}\text { Estimated } \\
\text { number of } \\
\text { annual } \\
\text { shipments }\end{array}$} & \multicolumn{2}{|c|}{$\begin{array}{c}\text { Radiological impacts } \\
\text { per shipment }\end{array}$} & \multicolumn{2}{|c|}{$\begin{array}{c}\text { Annual radiological } \\
\text { impacts }\end{array}$} & \multicolumn{2}{|c|}{ Annual health effects } \\
\hline & & $\begin{array}{c}\text { Crew } \\
\text { (person-rem/ } \\
\text { shipment) }\end{array}$ & $\begin{array}{c}\text { Public } \\
\text { (person-remi/ } \\
\text { shipment) }\end{array}$ & $\begin{array}{c}\text { Crew } \\
\text { (person-rem/ } \\
\text { year) }\end{array}$ & $\begin{array}{c}\text { Public } \\
\text { (person-rem/ } \\
\text { year) }\end{array}$ & 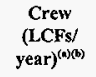 & $\begin{array}{c}\text { Public } \\
\text { (LCFs/ } \\
\text { year) }^{(a)(b)}\end{array}$ \\
\hline $\mathrm{Ac}-227$ & 1 & $2.76 \mathrm{E}-12$ & $\cdot 4.63 \mathrm{E}-13$ & $2.76 \mathrm{E}-12$ & $4.63 \mathrm{E}-13$ & $<1 \mathrm{E}-10$ & $<1 E-10$ \\
\hline $\mathrm{Au}-198$ & 25 & $5.20 \mathrm{E}-05$ & $8.71 \mathrm{E}-06$ & $1.30 \mathrm{E}-03$ & $2.18 \mathrm{E}-04$ & $5.20 \mathrm{E}-07$ & $1.09 \mathrm{E}-07$ \\
\hline $\mathrm{Cd}-109$ & 1 & $8.58 \mathrm{E}-25$ & $1.44 \mathrm{E}-25$ & $8.58 \mathrm{E}-25$ & $1.44 \mathrm{E}-25$ & $<1 \mathrm{E}-10$ & $<1 \mathrm{E}-10$ \\
\hline $\mathrm{Cu}-64$ & 25 & $2.85 \mathrm{E}-05$ & $4.78 \mathrm{E}-06$ & $7.13 \mathrm{E}-04$ & $1.20 \mathrm{E}-04$ & $2.85 \mathrm{E}-07$ & $5.98 \mathrm{E}-08$ \\
\hline $\mathrm{Cu}-67$ & 25 & $2.21 \mathrm{E}-13$ & $3.7 \mathrm{tE}-14$ & $5.53 \mathrm{E}-12$ & $9.28 \mathrm{E}-13$ & $2.21 \mathrm{E}-15$ & $4.64 \mathrm{E}-16$ \\
\hline Gd-153 & 1 & $5.92 \mathrm{E}-22$ & $9.92 \mathrm{E}-23$ & $5.92 \mathrm{E}-22$ & $9.92 \mathrm{E}-23$ & $<$ lE-10 & $<1 \mathrm{E}-10$ \\
\hline Ho- 166 & 25 & $1.81 \mathrm{IE}-04$ & $3.03 \mathrm{E}-05$ & 4.52E-03 & $7.58 \mathrm{E}-04$ & $1.81 \mathrm{E}-06$ & $3.79 \mathrm{E}-07$ \\
\hline $\mathrm{I}-125$ & 1 & $9.77 \mathrm{E}-24$ & $1.64 \mathrm{E}-24$ & $9.77 \mathrm{E}-24$ & $1.64 \mathrm{E}-24$ & $<1 \mathrm{E}-10$ & $<1 \mathrm{E}-10$ \\
\hline$[-131$ & 10 & $1.28 \mathrm{E}-04$ & $2.14 \mathrm{E}-05$ & $1.28 \mathrm{E}-03$ & $2.14 \mathrm{E}-04$ & $5.10 \mathrm{E}-07$ & $1.07 \mathrm{E}-07$ \\
\hline $\mathrm{Ir}-192$ & 1 & $3.02 \mathrm{E}-04$ & $5.06 \mathrm{E}-05$ & $3.02 \mathrm{E}-04$ & $5.06 \mathrm{E}-05$ & $1.21 \mathrm{E}-07$ & $2.53 \mathrm{E}-08$ \\
\hline Lu-177 & 10 & $4.50 \mathrm{E}-18$ & $7.55 \mathrm{E}-19$ & $4.50 \mathrm{E}-17$ & $7.55 \mathrm{E}-18$ & $<1 \mathrm{E}-10$ & $<1 \mathrm{E}-10$ \\
\hline Mo-99 & 25 & $3.02 \mathrm{E}-04$ & $5.06 \mathrm{E}-05$ & $7.54 \mathrm{E}-03$ & $1.26 \mathrm{E}-03$ & $3.02 \mathrm{E}-06$ & $6.32 \mathrm{E}-07$ \\
\hline Os $-194^{(\mathrm{c})}$ & I & $3.02 \mathrm{E}-04$ & $5.06 \mathrm{E}-05$ & $3.02 \mathrm{E}-04$ & $5.06 \mathrm{E}-05$ & $1.21 \mathrm{E}-07$ & $2.53 \mathrm{E}-08$ \\
\hline$P-32^{(s)}$ & 5 & $0.00 \mathrm{E}+00$ & $0.00 \mathrm{E}+00$ & $0.00 \mathrm{E}+00$ & $0.00 \mathrm{E}+00$ & $0.00 \mathrm{E}+00$ & $0.00 \mathrm{E}+00$ \\
\hline $\mathrm{p}-33^{(0)}$ & 3 & $0.00 \mathrm{E}+00$ & $0.00 \mathrm{E}+00$ & $0.00 \mathrm{E}+00$ & $0.00 \mathrm{E}+00$ & $0.00 \mathrm{E}+00$ & $0.00 \mathrm{E}+00$ \\
\hline $\mathrm{Pd}-103$ & 5 & 3.13E-13 & $5.25 \mathrm{E}-14$ & 1.57E-12 & $2.63 \mathrm{E}-13$ & $<1 \mathrm{E}-10$ & $<1 \mathrm{E}-10$ \\
\hline Pt-195m & 5 & $7.89 \mathrm{E}-10$ & $1.32 \mathrm{E}-10$ & $3.94 \mathrm{E}-09$ & $6.61 \mathrm{E}-10$ & $<1 \mathrm{E}-10$ & $<1 \mathrm{E}-10$ \\
\hline $\operatorname{Re}-186$ & 10 & $3.02 \mathrm{E}-04$ & $5.06 \mathrm{E}-05$ & $3.02 \mathrm{E}-03$ & $5.06 \mathrm{E}-04$ & $1.21 \mathrm{E}-06$ & $2.53 \mathrm{E}-07$ \\
\hline $\mathrm{Sc}-47$ & 25 & $2.16 \mathrm{E}-18$ & $3.63 \mathrm{E}-19$ & $5.41 \mathrm{E}-17$ & $9.07 \mathrm{E}-18$ & $<1 \mathrm{E}-10$ & $<1 \mathrm{E}-10$ \\
\hline $\mathrm{Se}-75$ & 1 & $7.59 \mathrm{E}-07$ & $1.27 \mathrm{E}-07$ & $7.59 \mathrm{E}-07$ & $1.27 \mathrm{E}-07$ & $3.03 \mathrm{E}-10$ & $<1 \mathrm{E}-10$ \\
\hline Sm-145 & 1 & $1.53 \mathrm{E}-06$ & $2.57 \mathrm{E}-07$ & 1.53E-06 & 2.57E-07 & $6.13 \mathrm{E}-10$ & $1.29 \mathrm{E}-10$ \\
\hline Sm-153 & 25 & $2.34 \mathrm{E}-06$ & $3.93 \mathrm{E}-07$ & $5.86 \mathrm{E}-05$ & $9.82 \mathrm{E}-06$ & $2.34 \mathrm{E}-08$ & $4.91 \mathrm{E}-09$ \\
\hline $\mathrm{Sn}-117 \mathrm{~m}$ & 5 & $1.42 \mathrm{E}-22$ & $2.38 \mathrm{E}-23$ & $7.11 \mathrm{E}-22$ & $1.19 \mathrm{E}-22$ & $<1 \mathrm{E}-10$ & $<1 \mathrm{E}-10$ \\
\hline Sr-85 & 1 & 8.44E-05 & $1.42 \mathrm{E}-05$ & $8.44 \mathrm{E}-05$ & $1.42 \mathrm{E}-05$ & $3.38 \mathrm{E}-08$ & $7.08 \mathrm{E}-09$ \\
\hline SI-89 & 3 & $2.37 \mathrm{E}-06$ & $3.97 \mathrm{E}-07$ & $5.92 \mathrm{E}-06$ & $9.92 \mathrm{E}-07$ & $2.37 \mathrm{E}-09$ & $4.96 \mathrm{E}-10$ \\
\hline Th-228 & 1 & $2.76 \mathrm{E}-12$ & $4.63 \mathrm{E}-13$ & $2.76 \mathrm{E}-12$ & $4.63 \mathrm{E}-13$ & $<1 \mathrm{E}-10$ & $<1 \mathrm{E}-10$ \\
\hline
\end{tabular}


HNF-1844, Rev. 0

Table 28. Routine Radiological Impacts for Truck Shipments of Separated Isotopes from the $\mathbf{3 2 5}$ Building to Pasco Airport

\begin{tabular}{|c|c|c|c|c|c|c|c|}
\hline \multirow[t]{2}{*}{ Isotope* } & \multirow{2}{*}{$\begin{array}{l}\text { Estimated } \\
\text { number of } \\
\text { annual } \\
\text { shipments }\end{array}$} & \multicolumn{2}{|c|}{$\begin{array}{c}\text { Radiological impacts } \\
\text { per shipment }\end{array}$} & \multicolumn{2}{|c|}{$\begin{array}{l}\text { Annual radiological } \\
\text { impacts }\end{array}$} & \multicolumn{2}{|c|}{ Annual health effects } \\
\hline & & $\begin{array}{c}\text { Crew } \\
\text { (person-rem/ } \\
\text { shipment) }\end{array}$ & $\begin{array}{l}\text { Public } \\
\text { (person-rem/ } \\
\text { shipment) }\end{array}$ & $\begin{array}{c}\text { Crew } \\
\text { (person-rem/ } \\
\text { year) }\end{array}$ & $\begin{array}{c}\text { Public } \\
\text { (person-rem/ } \\
\text { year) }\end{array}$ & 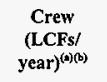 & $\begin{array}{l}\text { Public } \\
\text { (LCFs/ } \\
\text { year) }^{(\omega)(b)}\end{array}$ \\
\hline Th-229 & 1 & See Th-228 & See Th-228 & See Th-228 & See Th-228 & See Th-228 & See Th-228 \\
\hline$W-188$ & 1 & $3.02 \mathrm{E}-04$ & $5.06 \mathrm{E}-05$ & $3.02 \mathrm{E}-04$ & $5.06 \mathrm{E}-05$ & $1.21 \mathrm{E}-07$ & $2.53 \mathrm{E}-08$ \\
\hline $\mathrm{Xe}-127$ & 3 & $2.64 \mathrm{E}-08$ & $4.43 \mathrm{E}-09$ & $6.61 \mathrm{E}-08$ & $1.11 \mathrm{E}-08$ & $<1 \mathrm{E}-10$ & $<1 \mathrm{E}-10$ \\
\hline$Y-91$ & 1 & $5.24 \mathrm{E}-05$ & $8.79 \mathrm{E}-06$ & $5.24 \mathrm{E}-05$ & 8.79E-06 & $2.10 \mathrm{E}-08$ & $4.40 \mathrm{E}-09$ \\
\hline
\end{tabular}

(a) Calculated using the methodology prescribed in ICRP 60 .

(b) Accident impacts are less than $1 \mathrm{E}-10$ health effects; insignificant contributors to annual and life-cycle transportation impacts.

(c) Dose Factors for Os-194 were not included in the MICROSHIELD libraries; therefore, a TI of $13 \mathrm{mrem} / \mathrm{hr}$ was assumed.

(d) P-32 and P-33 decay does not emit gamma radiation. 
HNF-1844, Rev. 0

Table 29. Routine Radiological Impacts for Truck Shipments of Medical Isotopes from Boston, Ma. Airport to Dupont-Merck

\begin{tabular}{|c|c|c|c|c|c|c|c|}
\hline \multirow[t]{2}{*}{ Isotope* } & \multirow{2}{*}{$\begin{array}{l}\text { Estimated } \\
\text { Number } \\
\text { of Annual } \\
\text { Shipments }\end{array}$} & \multicolumn{2}{|c|}{$\begin{array}{l}\text { Radiological Impacts } \\
\text { per Shipment }\end{array}$} & \multicolumn{2}{|c|}{$\begin{array}{l}\text { Annual Radiological } \\
\text { Impacts }\end{array}$} & \multicolumn{2}{|c|}{ Annual Health Effects } \\
\hline & & $\begin{array}{c}\text { Crew } \\
\text { (person- } \\
\text { rem/ } \\
\text { shipment) }\end{array}$ & $\begin{array}{l}\text { Public } \\
\text { (person- } \\
\text { rem/ } \\
\text { shipment) }\end{array}$ & $\begin{array}{c}\text { Crew } \\
\text { (person- } \\
\text { rem/ year) }\end{array}$ & $\begin{array}{c}\text { Public } \\
\text { (person- } \\
\text { rem/ year) }\end{array}$ & 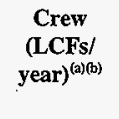 & $\begin{array}{c}\text { Public } \\
(\mathbf{L C F} / \\
\text { year) }^{(\mathrm{a})(\mathrm{b})}\end{array}$ \\
\hline Ac- 227 & 1 & $5.43 \mathrm{E}-13$ & 1.33E-12 & $5.43 \mathrm{E}-13$ & $1.33 \mathrm{E}-12$ & $<1 \mathrm{E}-10$ & $<1 \mathrm{E}-10$ \\
\hline $\mathrm{Au}-198$ & 25 & $1.02 \mathrm{E}-05$ & $2.51 \mathrm{E}-05$ & $2.55 \mathrm{E}-04$ & $6.27 \mathrm{E}-04$ & $1.02 \mathrm{E}-07$ & $3.14 \mathrm{E}-07$ \\
\hline Cd-109 & 1 & $1.69 \mathrm{E}-25$ & $4.14 \mathrm{E}-25$ & $1.69 \mathrm{E}-25$ & $4.14 \mathrm{E}-25$ & $<1 \mathrm{E}-10$ & $<1 \mathrm{E}-10$ \\
\hline $\mathrm{Cu}-64$ & 25 & $5.61 \mathrm{E}-06$ & $1.38 \mathrm{E}-05$ & $1.40 \mathrm{E}-04$ & $3.44 \mathrm{E}-04$ & $5.61 \mathrm{E}-08$ & $1.72 \mathrm{E}-07$ \\
\hline Cu-67 & 25 & $4.35 \mathrm{E}-14$ & $1.07 \mathrm{E}-13$ & $1.09 \mathrm{E}-12$ & $2.67 \mathrm{E}-12$ & $<1 \mathrm{E}-10$ & $<1 \mathrm{E}-10$ \\
\hline Gd-153 & 1 & $1.16 \mathrm{E}-22$ & $2.86 \mathrm{E}-22$ & $1.16 \mathrm{E}-22$ & $2.86 \mathrm{E}-22$ & $<1 \mathrm{E}-10$ & $<1 \mathrm{E}-10$ \\
\hline Ho-166 & 25 & $3.55 \mathrm{E}-05$ & $8.72 \mathrm{E}-05$ & $8.88 \mathrm{E}-04$ & $2.18 \mathrm{E}-03$ & 3.55E-07 & $1.09 \mathrm{E}-06$ \\
\hline I-125 & 1 & $1.92 \mathrm{E}-24$ & $4.72 \mathrm{E}-24$ & $1.92 \mathrm{E}-24$ & $4.72 \mathrm{E}-24$ & $<1 \mathrm{E}-10$ & $<1 \mathrm{E}-10$ \\
\hline $\mathrm{I}-131$ & 10 & $2.51 \mathrm{E}-05$ & $6.16 \mathrm{E}-05$ & $2.51 \mathrm{E}-04$ & $6.16 \mathrm{E}-04$ & $1.00 \mathrm{E}-07$ & $3.08 \mathrm{E}-07$ \\
\hline Ir-192 & 1 & $5.93 \mathrm{E}-05$ & $1.46 \mathrm{E}-04$ & $5.93 \mathrm{E}-05$ & $1.46 \mathrm{E}-04$ & $2.37 \mathrm{E}-08$ & $7.28 \mathrm{E}-08$ \\
\hline Lu-177 & 10 & 8.85 E-19 & $2.17 \mathrm{E}-18$ & $8.85 \mathrm{E}-18$ & $2.17 \mathrm{E}-17$ & $<1 \mathrm{E}-10$ & $<1 \mathrm{E}-10$ \\
\hline Mo-99 & 25 & $5.93 \mathrm{E}-05$ & $1.46 \mathrm{E}-04$ & $1.48 \mathrm{E}-03$ & $3.64 \mathrm{E}-03$ & $5.93 \mathrm{E}-07$ & $1.82 \mathrm{E}-06$ \\
\hline Os-194(c) & 1 & $5.93 \mathrm{E}-05$ & $1.46 \mathrm{E}-04$ & 5.93E-05 & $1.46 \mathrm{E}-04$ & $2.37 \mathrm{E}-08$ & $7.28 \mathrm{E}-08$ \\
\hline $\mathrm{P}-32^{(\mathrm{d})}$ & 5 & $0.00 \mathrm{E}+00$ & $0.00 \mathrm{E}+00$ & $0.00 \mathrm{E}+00$ & $0.00 \mathrm{E}+00$ & $0.00 \mathrm{E}+00$ & $0.00 \mathrm{E}+00$ \\
\hline$P-33^{(d)}$ & 3 & $0.00 \mathrm{E}+00$ & $0.00 \mathrm{E}+00$ & $0.00 \mathrm{E}+00$ & $0.00 \mathrm{E}+00$ & $0.00 \mathrm{E}+00$ & $0.00 \mathrm{E}+00$ \\
\hline $\mathrm{Pd}-103$ & 5 & $6.16 \mathrm{E}-14$ & $1.51 \mathrm{E}-13$ & $3.08 \mathrm{E}-13$ & $7.56 \mathrm{E}-13$ & $<1 \mathrm{E}-10$ & $<1 \mathrm{E}-10$ \\
\hline Pt-195m & 5 & $1.55 \mathrm{E}-10$ & $3.81 \mathrm{E}-10$ & $7.75 \mathrm{E}-10$ & $1.90 \mathrm{E}-09$ & $<1 \mathrm{E}-10$ & $<1 \mathrm{E}-10$ \\
\hline $\operatorname{Re}-186$ & 10 & 5.93E-05 & $1.46 \mathrm{E}-04$ & $5.93 \mathrm{E}-04$ & $1.46 \mathrm{E}-03$ & $2.37 \mathrm{E}-07$ & $7.28 \mathrm{E}-07$ \\
\hline $\mathrm{Sc}-47$ & 25 & $4.25 \mathrm{E}-19$ & $1.04 \mathrm{E}-18$ & $1.06 \mathrm{E}-17$ & $2.61 \mathrm{E}-17$ & $<1 \mathrm{E}-10$ & $<1 \mathrm{E}-10$ \\
\hline Se-75 & 1 & $1.49 \mathrm{E}-07$ & $3.66 \mathrm{E}-07$ & $1.49 \mathrm{E}-07$ & $3.66 \mathrm{E}-07$ & $<1 \mathrm{E}-10$ & $1.83 \mathrm{E}-10$ \\
\hline Sm-145 & 1 & $3.01 \mathrm{E}-07$ & $7.40 \mathrm{E}-07$ & $3.01 \mathrm{E}-07$ & $7.40 \mathrm{E}-07$ & $1.21 \mathrm{E}-10$ & $3.70 \mathrm{E}-10$ \\
\hline Sm-153 & 25 & $4.61 \mathrm{E}-07$ & $1.13 \mathrm{E}-06$ & 1.15E-05 & $2.83 \mathrm{E}-05$ & 4.61E-09 & $1.41 \mathrm{E}-08$ \\
\hline
\end{tabular}


HNF-1844, Rev. 0

Table 29. Routine Radiological Impacts for Truck Shipments of Medical Isotopes from Boston, Ma. Airport to Dupont-Merck

\begin{tabular}{|c|c|c|c|c|c|c|c|}
\hline \multirow[t]{2}{*}{ Isotope* } & \multirow{2}{*}{$\begin{array}{l}\text { Estimated } \\
\text { Number } \\
\text { of Annual } \\
\text { Shipments }\end{array}$} & \multicolumn{2}{|c|}{$\begin{array}{l}\text { Radiological Impacts } \\
\text { per Shipment }\end{array}$} & \multicolumn{2}{|c|}{$\begin{array}{l}\text { Annual Radiological } \\
\text { Impacts }\end{array}$} & \multicolumn{2}{|c|}{ Annual Health Effects } \\
\hline & & $\begin{array}{c}\text { Crew } \\
\text { (person- } \\
\text { rem/ } \\
\text { shipment) }\end{array}$ & $\begin{array}{c}\text { Public } \\
\text { (person- } \\
\text { rem/ } \\
\text { shipment) }\end{array}$ & $\begin{array}{c}\text { Crew } \\
\text { (person- } \\
\text { rem/ year) }\end{array}$ & $\begin{array}{c}\text { Public } \\
\text { (person- } \\
\text { rem/ year) }\end{array}$ & $\begin{array}{c}\text { Crew } \\
\text { (LCFs/ } \\
\text { year) }^{(\mathrm{a})(\mathrm{b})}\end{array}$ & $\begin{array}{c}\text { Public } \\
\text { (LCFs/ }^{\text {year) }}{ }^{\text {(a)(b) }}\end{array}$ \\
\hline $\mathrm{Sn}-117 \mathrm{~m}$ & 5 & $2.80 \mathrm{E}-23$ & $6.87 \mathrm{E}-23$ & $1.40 \mathrm{E}-22$ & $3.43 \mathrm{E}-22$ & $<1 \mathrm{E}-10$ & $<1 \mathrm{E}-10$ \\
\hline Sr-85 & 1 & $1.66 \mathrm{E}-05$ & $4.08 \mathrm{E}-05$ & $1.66 \mathrm{E}-05$ & 4.08E-05 & $6.64 \mathrm{E}-09$ & $2.04 \mathrm{E}-08$ \\
\hline Sr-89 & 3 & $4.65 \mathrm{E}-07$ & $1.14 \mathrm{E}-06$ & $1.16 \mathrm{E}-06$ & $2.86 \mathrm{E}-06$ & $4.65 \mathrm{E}-10$ & $1.43 \mathrm{E}-09$ \\
\hline Th-228 & 1 & $5.43 \mathrm{E}-13$ & $1.33 \mathrm{E}-12$ & $5.43 \mathrm{E}-13$ & $1.33 \mathrm{E}-12$ & $<1 \mathrm{E}-10$ & $<1 \mathrm{E}-10$ \\
\hline Th-229 & 1 & See Th-228 & See $T h-228$ & See Th-228 & See Th-228 & See Th- 228 & $\begin{array}{c}\text { See } \\
\text { Th-228 }\end{array}$ \\
\hline W-188 & 1 & $5.93 \mathrm{E}-05$ & $1.46 \mathrm{E}-04$ & $5.93 \mathrm{E}-05$ & $1.46 \mathrm{E}-04$ & 2.37E-08 & $7.28 \mathrm{E}-08$ \\
\hline $\mathrm{Xe}-127$ & 3 & $5.20 \mathrm{E}-09$ & $1.28 \mathrm{E}-08$ & $1.30 \mathrm{E}-08$ & $3.19 \mathrm{E}-08$ & $<1 \mathrm{E}-10$ & $<1 \mathrm{E}-10$ \\
\hline Y-91 & 1 & $1.03 \mathrm{E}-05$ & $2.53 \mathrm{E}-05$ & $1.03 \mathrm{E}-05$ & $2.53 \mathrm{E}-05$ & $4.12 \mathrm{E}-09$ & $1.27 \mathrm{E}-08$ \\
\hline
\end{tabular}

(a) Calculated using the methodology prescribed in ICRP 60.

(b) Accident impacts are less than $1 \mathrm{E}-10$ health effects; insignificant contributors to annual and life-cycle transportation impacts.

(c) Dose Factors for Os-194 were not included in the MICROSHIELD libraries; therefore, a TI of $13 \mathrm{mrem} / \mathrm{hr}$ was assumed.

(d) P-32 and P-33 decay does not emit gamma radiation. 
HNF-1844, Rev, 0

Table 30. Routine Radiological Impacts for Truck Shipments of Medical Isotopes from Chicago, II. Airport to Amersham Mediphysics

\begin{tabular}{|c|c|c|c|c|c|c|c|}
\hline \multirow[t]{2}{*}{ Isotope* } & \multirow{2}{*}{$\begin{array}{c}\text { Estimated } \\
\text { Number } \\
\text { of Annual } \\
\text { Shipments }\end{array}$} & \multicolumn{2}{|c|}{$\begin{array}{c}\text { Radiological Impacts } \\
\text { per Shipment }\end{array}$} & \multicolumn{2}{|c|}{$\begin{array}{l}\text { Annual Radiological } \\
\text { Impacts }\end{array}$} & \multicolumn{2}{|c|}{ Annual Health Effects } \\
\hline & & $\begin{array}{c}\text { Crew } \\
\text { (person- } \\
\text { rem/ } \\
\text { shipment) }\end{array}$ & $\begin{array}{c}\text { Public } \\
\text { (person- } \\
\text { rem/ } \\
\text { shipment) }\end{array}$ & $\begin{array}{c}\text { Crew } \\
\text { (person- } \\
\text { rem/ year) }\end{array}$ & $\begin{array}{c}\text { Public } \\
\text { (person- } \\
\text { rem/ year) }\end{array}$ & 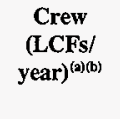 & 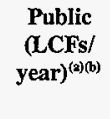 \\
\hline Ac- 227 & 1 & $5.37 \mathrm{E}-12$ & $8.59 \mathrm{E}-13$ & $5.37 \mathrm{E}-12$ & $8.59 \mathrm{E}-13$ & $<1 \mathrm{E}-10$ & $<1 \mathrm{E}-10$ \\
\hline $\mathrm{Au}-198$ & 25 & $1.01 \mathrm{E}-04$ & $1.62 \mathrm{E}-05$ & $2.53 \mathrm{E}-03$ & $4.04 \mathrm{E}-04$ & $1.01 \mathrm{E}-06$ & $2.02 \mathrm{E}-07$ \\
\hline Cd-109 & 1 & $1.67 \mathrm{E}-24$ & $2.67 \mathrm{E}-25$ & $1.67 \mathrm{E}-24$ & $2.67 \mathrm{E}-25$ & $<1 \mathrm{E}-10$ & $<1 \mathrm{E}-10$ \\
\hline $\mathrm{Cu}-64$ & 25 & $5.55 \mathrm{E}-05$ & $8.88 \mathrm{E}-06$ & $1.39 \mathrm{E}-03$ & $2.22 \mathrm{E}-04$ & $5.55 \mathrm{E}-07$ & $1.11 \mathrm{E}-07$ \\
\hline $\mathrm{Cu}-67$ & 25 & $4.30 \mathrm{E}-13$ & $6.89 \mathrm{E}-14$ & $1.08 \mathrm{E}-11$ & $1.72 \mathrm{E}-12$ & $<1 E-10$ & $<1 \mathrm{E}-10$ \\
\hline Gd-153 & 1 & $1.15 \mathrm{E}-21$ & $1.84 \mathrm{E}-22$ & $1.15 \mathrm{E}-21$ & $1.84 \mathrm{E}-22$ & $<1 E-10$ & $<1 \mathrm{E}-10$ \\
\hline Ho-166 & 25 & $3.51 \mathrm{E}-04$ & $5.62 \mathrm{E}-05$ & $8.78 \mathrm{E}-03$ & $1.41 \mathrm{E}-03$ & $3.51 \mathrm{E}-06$ & 7.03E-07 \\
\hline I- 125 & 1 & $1.90 \mathrm{E}-23$ & $3.04 \mathrm{E}-24$ & $1.90 \mathrm{E}-23$ & $3.04 \mathrm{E}-24$ & $<1 \mathrm{E}-10$ & $<1 \mathrm{E}-10$ \\
\hline I-131 & 10 & $2.48 \mathrm{E}-04$ & $3.97 \mathrm{E}-05$ & $2.48 \mathrm{E}-03$ & $3.97 \mathrm{E}-04$ & $9.92 \mathrm{E}-07$ & $1.99 \mathrm{E}-07$ \\
\hline Ir-192 & 1 & $5.86 \mathrm{E}-04$ & 9.39E-0S & $5.86 \mathrm{E}-04$ & $9.39 \mathrm{E}-05$ & $2.35 \mathrm{E}-07$ & $4.69 \mathrm{E}-08$ \\
\hline Lü-177 & 10 & $8.75 \mathrm{E}-18$ & $1.40 \mathrm{E}-18$ & $8.75 \mathrm{E}-17$ & $1.40 \mathrm{E}-17$ & $<1 \mathrm{E}-10$ & $<1 \mathrm{E}-10$ \\
\hline Mo-99 & 25 & $5.86 \mathrm{E}-04$ & $9.39 \mathrm{E}-05$ & $1.47 \mathrm{E}-02$ & $2.35 \mathrm{E}-03$ & $5.86 \mathrm{E}-06$ & $1.17 \mathrm{E}-06$ \\
\hline Os $-194^{(c)}$ & 1 & $5.86 \mathrm{E}-04$ & $9.39 \mathrm{E}-05$ & $5.86 \mathrm{E}-04$ & $9.39 \mathrm{E}-05$ & $2.35 \mathrm{E}-07$ & $4.69 \mathrm{E}-08$ \\
\hline P-32 (d) & 5 & $0.00 \mathrm{E}+00$ & $0.00 \mathrm{E}+00$ & $0.00 \mathrm{E}+00$ & $0.00 \mathrm{E}+00$ & $0.00 \mathrm{E}+00$ & $0.00 \mathrm{E}+00$ \\
\hline $\mathrm{P}-33^{(d)}$ & 3 & $0.00 \mathrm{E}+00$ & $0.00 \mathrm{E}+00$ & $0.00 \mathrm{E}+00$ & $0.00 \mathrm{E}+00$ & $0.00 \mathrm{E}+00$ & $0.00 \mathrm{E}+00$ \\
\hline Pd-103 & 5 & $6.09 \mathrm{E}-13$ & $9.75 \mathrm{E}-14$ & $3.04 \mathrm{E}-12$ & $4.87 \mathrm{E}-13$ & $<1$ E- 10 & $<1 \mathrm{E}-10$ \\
\hline Pt-195m & 5 & $1.53 \mathrm{E}-09$ & $2.45 \mathrm{E}-10$ & $7.67 \mathrm{E}-09$ & $1.23 \mathrm{E}-09$ & $<1 \mathrm{E}-10$ & $<1 \mathrm{E}-10$ \\
\hline Re-186 & 10 & $5.86 \mathrm{E}-04$ & $9.39 \mathrm{E}-05$ & $5.86 \mathrm{E}-03$ & 9.39E-04 & 2.35E-06 & $4.69 \mathrm{E}-07$ \\
\hline Sc-47 & 25 & $4.21 \mathrm{E}-18$ & $6.74 \mathrm{E}-19$ & $1.05 \mathrm{E}-16$ & $1.68 \mathrm{E}-17$ & $<1 \mathrm{E}-10$ & $<1 \mathrm{E}-10$ \\
\hline Se-75 & 1 & $1.47 \mathrm{E}-06$ & $2.36 \mathrm{E}-07$ & $1.47 \mathrm{E}-06$ & $2.36 \mathrm{E}-07$ & $5.90 \mathrm{E}-10$ & $1.18 \mathrm{E}-10$ \\
\hline Sm-145 & 1 & $2.98 \mathrm{E}-06$ & $4.77 \mathrm{E}-07$ & $2.98 \mathrm{E}-06$ & $4.77 \mathrm{E}-07$ & $1.19 \mathrm{E}-09$ & $2.39 \mathrm{E}-10$ \\
\hline $\mathrm{Sm}-153$ & 25 & $4.56 \mathrm{E}-06$ & $7.29 \mathrm{E}-07$ & $1.14 \mathrm{E}-04$ & $1.82 \mathrm{E}-05$ & $4.56 \mathrm{E}-08$ & $9.12 \mathrm{E}-09$ \\
\hline
\end{tabular}


HNF-1844, Rev. 0

Table 30. Routine Radiological Impacts for Truck Shipments of Medical Isotopes from Chicago, II. Airport to Amersham Mediphysics

\begin{tabular}{|c|c|c|c|c|c|c|c|}
\hline \multirow[t]{2}{*}{ Isotope* } & \multirow{2}{*}{$\begin{array}{l}\text { Estimated } \\
\text { Number } \\
\text { of Annual } \\
\text { Shipments }\end{array}$} & \multicolumn{2}{|c|}{$\begin{array}{l}\text { Radiological Impacts } \\
\text { per Shipment }\end{array}$} & \multicolumn{2}{|c|}{$\begin{array}{l}\text { Annual Radiological } \\
\text { Impacts }\end{array}$} & \multicolumn{2}{|c|}{ Annual Health Effects } \\
\hline & & $\begin{array}{c}\text { Crew } \\
\text { (person- } \\
\text { rem/ } \\
\text { shipment) }\end{array}$ & $\begin{array}{c}\text { Public } \\
\text { (person- } \\
\text { rem/ } \\
\text { shipment) }\end{array}$ & $\begin{array}{c}\text { Crew } \\
\text { (person- } \\
\text { rem/ year) }\end{array}$ & $\begin{array}{c}\text { Public } \\
\text { (person- } \\
\text { rem/ year) }\end{array}$ & $\begin{array}{c}\text { Crew } \\
\text { (LCFs/ } \\
{\text { year })^{(\mathrm{a})(\mathrm{b})}}^{\text {(n) }}\end{array}$ & $\begin{array}{c}\text { Public } \\
\text { (LCFs/ }^{(a) b} \\
\text { year }^{(\mathrm{a})(\mathrm{b})}\end{array}$ \\
\hline $\mathrm{Sn}-117 \mathrm{~m}$ & 5 & $2.76 \mathrm{E}-22$ & $4.43 \mathrm{E}-23$ & $1.38 \mathrm{E}-21$ & $2.21 \mathrm{E}-22$ & $<1 \mathrm{E}-10$ & $<1 \mathrm{E}-10$ \\
\hline $\mathrm{Sr}-85$ & 1 & $1.64 \mathrm{E}-04$ & $2.63 \mathrm{E}-05$ & $1.64 \mathrm{E}-04$ & $2.63 \mathrm{E}-05$ & $6.57 \mathrm{E}-08$ & $1.31 \mathrm{E}-08$ \\
\hline Sr-89 & 3 & $4.60 \mathrm{E}-06$ & $7.36 \mathrm{E}-07$ & $1.15 \mathrm{E}-05$ & $1.84 \mathrm{E}-06$ & $4.60 \mathrm{E}-09$ & $9.21 \mathrm{E}-10$ \\
\hline Th-228 & 1 & $5.37 \mathrm{E}-12$ & $8.59 \mathrm{E}-13$ & $5.37 \mathrm{E}-12$ & $8.59 \mathrm{E}-13$ & $<1 \mathrm{E}-10$ & $<1 \mathrm{E}-10$ \\
\hline $\operatorname{Th}-229$ & 1 & See Th- 228 & See Th-228 & See Th-228 & See Th-228 & See Th- 228 & $\begin{array}{c}\text { See } \\
\text { Th-228 }\end{array}$ \\
\hline W-188 & 1 & $5.86 \mathrm{E}-04$ & $9.39 \mathrm{E}-05$ & $5.86 \mathrm{E}-04$ & 9.39E-05 & $2.35 \mathrm{E}-07$ & $4.69 \mathrm{E}-08$ \\
\hline Xe-127 & 3 & $5.14 \mathrm{E}-08$ & 8.23E-09 & $1.29 \mathrm{E}-07$ & $2.06 \mathrm{E}-08$ & $<1 \mathrm{E}-10$ & $<1 \mathrm{E}-10$ \\
\hline Y-91 & 1 & $1.02 \mathrm{E}-04$ & $1.63 \mathrm{E}-05$ & $1.02 \mathrm{E}-04$ & $1.63 \mathrm{E}-05$ & $4.08 \mathrm{E}-08$ & $8.16 \mathrm{E}-09$ \\
\hline
\end{tabular}

(a) Calculated using the methodology prescribed in ICRP 60

(b) Accident impacts are less than $1 \mathrm{E}-10$ health effects; insignificant contributors to annual and life-cycle transportation impacts.

(c) Dose Factors for Os-194 were not included in the MICROSHIELD libraries; therefore, a TI of $13 \mathrm{mrem} / \mathrm{hr}$ was assumed.

(d) P-32 and P-33 decay does not emit gamma radiation. 
HNF-1844, Rev. 0

Table 31. Routine Radiological Impacts for Truck Shipments of Medical Isotopes from St. Louis, Mo. Airport to Malinckrodt

\begin{tabular}{|c|c|c|c|c|c|c|c|}
\hline \multirow[t]{2}{*}{ Isotope* } & \multirow{2}{*}{$\begin{array}{l}\text { Estimated } \\
\text { Number } \\
\text { of Annual } \\
\text { Shipments }\end{array}$} & \multicolumn{2}{|c|}{$\begin{array}{c}\text { Radiological Impacts } \\
\text { per Shipment }\end{array}$} & \multicolumn{2}{|c|}{$\begin{array}{l}\text { Annual Radiological } \\
\text { Impacts }\end{array}$} & \multicolumn{2}{|c|}{ Annual Health Effects } \\
\hline & & $\begin{array}{c}\text { Crew } \\
\text { (person- } \\
\text { rem/ } \\
\text { shipment) }\end{array}$ & $\begin{array}{l}\text { Public } \\
\text { (person- } \\
\text { rem/ } \\
\text { shipment) }\end{array}$ & $\begin{array}{c}\text { Crew } \\
\text { (person- } \\
\text { rem/ year) }\end{array}$ & $\begin{array}{c}\text { Public } \\
\text { (person- } \\
\text { rem/ year) }\end{array}$ & 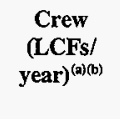 & $\begin{array}{c}\text { Public } \\
\text { (LCFs/ } \\
\text { year) }^{(2)(b)}\end{array}$ \\
\hline Ac-227 & 1 & $2.14 \mathrm{E}-12$ & $6.84 \mathrm{E}-13$ & $2.14 \mathrm{E}-12$ & $6.84 \mathrm{E}-13$ & $<1 \mathrm{E}-10$ & $<1 \mathrm{E}-10$ \\
\hline $\mathrm{Au}-198$ & 25 & $4.03 \mathrm{E}-05$ & $1.29 \mathrm{E}-05$ & $1.01 \mathrm{E}-03$ & $3.22 \mathrm{E}-04$ & $4.03 \mathrm{E}-07$ & $1.61 \mathrm{E}-07$ \\
\hline Cd-109 & 1 & $6.66 \mathrm{E}-25$ & $2.13 \mathrm{E}-25$ & $6.66 \mathrm{E}-25$ & $2.13 \mathrm{E}-25$ & $<1 \mathrm{E}-10$ & $<1 \mathrm{E}-10$ \\
\hline $\mathrm{Cu}-64$ & 25 & $2.21 \mathrm{E}-05$ & $7.07 \mathrm{E}-06$ & $5.54 \mathrm{E}-04$ & $1.77 \mathrm{E}-04$ & $2.21 \mathrm{E}-07$ & $8.84 \mathrm{E}-08$ \\
\hline $\mathrm{Cu}-67$ & 25 & $1.72 \mathrm{E}-13$ & $5.49 \mathrm{E}-14$ & $4.29 \mathrm{E}-12$ & $1.37 \mathrm{E}-12$ & $<1 E-10$ & $<1 \mathrm{E}-10$ \\
\hline Gd-153 & 1 & $4.59 \mathrm{E}-22$ & $1.47 \mathrm{E}-22$ & $4.59 \mathrm{E}-22$ & $1.47 \mathrm{E}-22$ & $<1 E-10$ & $<1 \mathrm{E}-10$ \\
\hline Ho-166 & 25 & $1.40 \mathrm{E}-04$ & $4.48 \mathrm{E}-05$ & $3.51 \mathrm{E}-03$ & $1.12 \mathrm{E}-03$ & $1.40 \mathrm{E}-06$ & $5.60 \mathrm{E}-07$ \\
\hline $\mathrm{I}-125$ & 1 & $7.58 \mathrm{E}-24$ & $2.42 \mathrm{E}-24$ & $7.58 \mathrm{E}-24$ & $2.42 \mathrm{E}-24$ & $<1 \mathrm{E}-10$ & $<1 \mathrm{E}-10$ \\
\hline I-131 & 10 & $9.90 \mathrm{E}-05$ & $3.16 \mathrm{E}-05$ & $9.90 \mathrm{E}-04$ & $3.16 \mathrm{E}-04$ & $3.96 \mathrm{E}-07$ & $1.58 \mathrm{E}-07$ \\
\hline Ir-192 & 1 & $2.34 \mathrm{E}-04$ & $7.48 \mathrm{E}-05$ & $2.34 \mathrm{E}-04$ & $7.48 \mathrm{E}-05$ & $9.36 \mathrm{E}-08$ & $3.74 \mathrm{E}-08$ \\
\hline Lu-177 & 10 & $3.49 \mathrm{E}-18$ & $1.12 \mathrm{E}-18$ & $3.49 \mathrm{E}-17$ & $1.12 \mathrm{E}-17$ & $<1 \mathrm{E}-10$ & $<1 \mathrm{E}-10$ \\
\hline Mo-99 & 25 & $2.34 \mathrm{E}-04$ & $7.48 \mathrm{E}-05$ & $5.85 \mathrm{E}-03$ & $1.87 \mathrm{E}-03$ & $2.34 \mathrm{E}-06$ & $9.34 \mathrm{E}-07$ \\
\hline Os-194(c) & 1 & $2.34 \mathrm{E}-04$ & $7.48 \mathrm{E}-05$ & $2.34 \mathrm{E}-04$ & $7.48 \mathrm{E}-05$ & $9.36 \mathrm{E}-08$ & $3.74 \mathrm{E}-08$ \\
\hline $\mathrm{P}-32^{(\mathrm{d})}$ & 5 & $0.00 \mathrm{E}+00$ & $0.00 \mathrm{E}+00$ & $0.00 \mathrm{E}+00$ & $0.00 \mathrm{E}+00$ & $0.00 \mathrm{E}+00$ & $0.00 \mathrm{E}+00$ \\
\hline$P-33^{(d)}$ & 3 & $0.00 \mathrm{E}+00$ & $0.00 \mathrm{E}+00$ & $0.00 \mathrm{E}+00$ & $0.00 \mathrm{E}+00$ & $0.00 \mathrm{E}+00$ & $0.00 \mathrm{E}+00$ \\
\hline Pd-103 & 5 & $2.43 \mathrm{E}-13$ & $7.76 \mathrm{E}-14$ & $1.22 \mathrm{E}-12$ & $3.88 \mathrm{E}-13$ & $<1 \mathrm{E}-10$ & $<1 \mathrm{E}-10$ \\
\hline Pt-195m & 5 & $6.12 \mathrm{E}-10$ & $1.96 \mathrm{E}-10$ & $3.06 \mathrm{E}-09$ & $9.78 \mathrm{E}-10$ & $<1 \mathrm{E}-10$ & $<1 \mathrm{E}-10$ \\
\hline Re-186 & 10 & $2.34 \mathrm{E}-04$ & $7.48 \mathrm{E}-05$ & $2.34 \mathrm{E}-03$ & $7.48 \mathrm{E}-04$ & $9.36 \mathrm{E}-07$ & $3.74 \mathrm{E}-07$ \\
\hline Sc- 47 & 25 & $1.68 \mathrm{E}-18$ & $5.36 \mathrm{E}-19$ & $4.20 \mathrm{E}-17$ & $1.34 \mathrm{E}-17$ & $<1 \mathrm{E}-10$ & $<1 \mathrm{E}-10$ \\
\hline Se-75 & 1 & $5.89 \mathrm{E}-07$ & $1.88 \mathrm{E}-07$ & $5.89 \mathrm{E}-07$ & $1.88 \mathrm{E}-07$ & $2.35 \mathrm{E}-10$ & $<1 \mathrm{E}-10$ \\
\hline Sm-145 & 1 & $1.19 \mathrm{E}-06$ & $3.80 \mathrm{E}-07$ & $1.19 \mathrm{E}-06$ & $3.80 \mathrm{E}-07$ & $4.76 \mathrm{E}-10$ & $1.90 \mathrm{E}-10$ \\
\hline $\mathrm{Sm}-153$ & 25 & $1.82 \mathrm{E}-06$ & $5.81 \mathrm{E}-07$ & $4.55 \mathrm{E}-05$ & $1.45 \mathrm{E}-05$ & $1.82 \mathrm{E}-08$ & $7.26 \mathrm{E}-09$ \\
\hline
\end{tabular}


HNF-1844, Rev. 0

Table 31. Routine Radiological Impacts for Truck Shipments of Medical Isotopes from St. Louis, Mo. Airport to Malinckrodt

\begin{tabular}{|c|c|c|c|c|c|c|c|}
\hline \multirow[t]{2}{*}{ Isotope* } & \multirow{2}{*}{$\begin{array}{l}\text { Estimated } \\
\text { Number } \\
\text { of Annual } \\
\text { Shipments }\end{array}$} & \multicolumn{2}{|c|}{$\begin{array}{c}\text { Radiological Impacts } \\
\text { per Shipment }\end{array}$} & \multicolumn{2}{|c|}{$\begin{array}{l}\text { Annual Radiological } \\
\text { Impacts }\end{array}$} & \multicolumn{2}{|c|}{ Annual Health Effects } \\
\hline & & $\begin{array}{c}\text { Crew } \\
\text { (person- } \\
\text { rem/ } \\
\text { shipment) }\end{array}$ & $\begin{array}{c}\text { Public } \\
\text { (person- } \\
\text { rem/ } \\
\text { shipment) }\end{array}$ & $\begin{array}{c}\text { Crew } \\
\text { (person- } \\
\text { rem/ year) }\end{array}$ & $\begin{array}{c}\text { Public } \\
\text { (person- } \\
\text { rem/ year) }\end{array}$ & 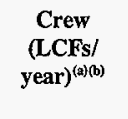 & 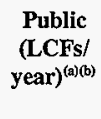 \\
\hline Sn-117m & 5 & $1.10 \mathrm{E}-22$ & $3.52 \mathrm{E}-23$ & $5.52 \mathrm{E}-22$ & $1.76 \mathrm{E}-22$ & $<1 E-10$ & $<1 \mathrm{E}-10$ \\
\hline St-85 & 1 & $6.55 \mathrm{E}-05$ & 2.09E-05 & $6.55 \mathrm{E}-05$ & $2.09 \mathrm{E}-05$ & $2.62 \mathrm{E}-08$ & $1.05 \mathrm{E}-08$ \\
\hline $\mathrm{Sr}-89$ & 3 & $1.84 \mathrm{E}-06$ & $5.87 \mathrm{E}-07$ & $4.59 \mathrm{E}-06$ & $1.47 \mathrm{E}-06$ & $1.84 \mathrm{E}-09$ & $7.33 \mathrm{E}-10$ \\
\hline Th-228 & 1 & $2.14 \mathrm{E}-12$ & $6.84 \mathrm{E}-13$ & $2.14 \mathrm{E}-12$ & $6.84 \mathrm{E}-13$ & $<1 \mathrm{E}-10$ & $<1 \mathrm{E}-10$ \\
\hline Th-229 & 1 & See $T h-228$ & See Th-228 & See Th-228 & See Th-228 & See Th-228 & $\begin{array}{c}\text { See } \\
\text { Th-228 }\end{array}$ \\
\hline W-188 & 1 & $2.34 \mathrm{E}-04$ & $7.48 \mathrm{E}-05$ & $2.34 \mathrm{E}-04$ & $7.48 \mathrm{E}-05$ & $9.36 \mathrm{E}-08$ & $3.74 \mathrm{E}-08$ \\
\hline $\mathrm{Xe}-127$ & 3 & $2.05 \mathrm{E}-08$ & $6.56 \mathrm{E}-09$ & $5.13 \mathrm{E}-08$ & $1.64 \mathrm{E}-08$ & $<1 \mathrm{E}-10$ & $<1 \mathrm{E}-10$ \\
\hline$Y-91$ & 1 & $4.07 \mathrm{E}-05$ & $1.30 \mathrm{E}-05$ & $4.07 \mathrm{E}-05$ & $1.30 \mathrm{E}-05$ & $1.63 \mathrm{E}-08$ & $6.50 \mathrm{E}-09$ \\
\hline
\end{tabular}

(a) Calculated using the methodology prescribed in ICRP 60

(b) Accident impacts are less than $1 \mathrm{E}-10$ health effects; insignificant contributors to annual and life-cycle transportation impacts.

(c) Dose Factors for Os-194 were not included in the MICROSHIELD libraries; therefore, a TI of $13 \mathrm{mrem} / \mathrm{hr}$ was assumed.

(d) P-32 and P-33 decay does not emit gamma radiation.

5.2.2.1 Radiological Impacts due to Routine Transportation by Air. The potential routine radiological impacts have been estimated for air shipments isotope products from the 325 Building to the distributors. The input data used to characterize each air shipment (e.g, population densities, and shipment speed and distances) are shown in Tables 14 and 15.

The results of the transportation impact calculations for commercial air shipments of medical isotopes are summarized in Table 32 (air transport to Boston), 33 (Chicago), and 34 (St. Louis). The tables present the routine exposures on a per-shipment basis. The tables present the results in units of person-rem/shipment and latent health effects. The latent health effects were calculated by multiplying the radiation exposures in person-rem by a conversion factor ( $5 \times 10^{-4}$ latent health effects per person-rem) taken from ICRP 60 . 
The air transportation impact results presented in the table are truncated at $1 \mathrm{E}-10$ health effects. Medical isotope shipments below this value are not expected to contribute significantly to total annual or total life-cycle health effects as they will be dominated by medical isotopes that result in higher per-shipment impacts.

Table 32. Routine Air Transportation Impacts for Medical Isotope Shipments from Pasco, Wa. to Boston, Ma.

\begin{tabular}{|c|c|c|c|c|c|c|c|}
\hline \multirow[t]{2}{*}{ Isotope* } & \multirow{2}{*}{$\begin{array}{l}\text { Number } \\
\text { of } \\
\text { Shipments } \\
\text { per Year }\end{array}$} & \multicolumn{2}{|c|}{$\begin{array}{l}\text { Radiological Impacts } \\
\text { per Shipment }\end{array}$} & \multicolumn{2}{|c|}{$\begin{array}{l}\text { Annual Radiological } \\
\text { Impacts }\end{array}$} & \multicolumn{2}{|c|}{ Annual Health Effects } \\
\hline & & $\begin{array}{c}\text { Crew } \\
\text { (person- } \\
\text { rem/ } \\
\text { shipment) }\end{array}$ & $\begin{array}{c}\text { Public } \\
\text { (person- } \\
\text { rem/ } \\
\text { shipment) }\end{array}$ & $\begin{array}{c}\text { Crew } \\
\text { (person- } \\
\text { rem/year) }\end{array}$ & $\begin{array}{c}\text { Public } \\
\text { (person- } \\
\text { rem/year) }\end{array}$ & 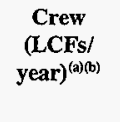 & $\begin{array}{c}\text { Public } \\
\text { (LCFs/ }^{(\text {Lear) }}\end{array}$ \\
\hline Ac-227 & 1 . & $2.08 \mathrm{E}-09$ & $1.05 \mathrm{E}-09$ & $2.08 \mathrm{E}-09$ & $1.05 \mathrm{E}-09$ & $<1 \mathrm{E}-10$ & $<1 \mathrm{E}-10$ \\
\hline $\mathrm{Au}-198$ & 25 & $3.92 \mathrm{E}-02$ & $1.98 \mathrm{E}-02$ & $9.80 \mathrm{E}-01$ & 4.96E-01 & $3.92 \mathrm{E}-04$ & $2.48 \mathrm{E}-04$ \\
\hline Cd-109 & 1 & $6.48 \mathrm{E}-22$ & $3.28 \mathrm{E}-22$ & $6.48 \mathrm{E}-22$ & $3.28 \mathrm{E}-22$ & $<1 \mathrm{E}-10$ & $<1 \mathrm{E}-10$ \\
\hline $\mathrm{Cu}-64$ & 25 & $2.15 \mathrm{E}-02$ & $1.09 \mathrm{E}-02$ & $5.38 \mathrm{E}-01$ & $2.72 \mathrm{E}-01$ & $2.15 \mathrm{E}-04$ & $1.36 \mathrm{E}-04$ \\
\hline $\mathrm{Cu}-67$ & 25 & $1.67 \mathrm{E}-10$ & $8.45 \mathrm{E}-11$ & $4.17 \mathrm{E}-09$ & $2.11 \mathrm{E}-09$ & $<1 \mathrm{E}-10$ & $<1 \mathrm{E}-10$ \\
\hline Gd-153 & 1 & $4.46 \mathrm{E}-19$ & $2.26 \mathrm{E}-19$ & $4.46 \mathrm{E}-19$ & $2.26 \mathrm{E}-19$ & $<1 \mathrm{E}-10$ & $<1 \mathrm{E}-10$ \\
\hline Ho-166 & 25 & $1.36 \mathrm{E}-01$ & $6.90 \mathrm{E}-02$ & $3.41 E+00$ & $1.72 \mathrm{E}+00$ & $1.36 \mathrm{E}-03$ & $8.62 \mathrm{E}-04$ \\
\hline $\mathrm{l}-125$ & 1 & $7.37 \mathrm{E}-21$ & $3.73 \mathrm{E}-21$ & $7.37 \mathrm{E}-21$ & $3.73 \mathrm{E}-21$ & $<1 \mathrm{E}-10$ & $<1 \mathrm{E}-10$ \\
\hline $\mathrm{I}-131$ & 10 & $9.63 \mathrm{E}-02$ & $4.87 \mathrm{E}-02$ & $9.63 \mathrm{E}-01$ & $4.87 \mathrm{E}-01$ & $3.85 \mathrm{E}-04$ & 2.43E-04 \\
\hline Ir-192 & 1 & $2.28 \mathrm{E}-01$ & $1.15 \mathrm{E}-01$ & $2.28 \mathrm{E}-01$ & $1.15 \mathrm{E}-01$ & $9.10 \mathrm{E}-05$ & $5.75 \mathrm{E}-05$ \\
\hline Lu-177 & 10 & $3.40 \mathrm{E}-15$ & 1.72E-15 & $3.40 \mathrm{E}-14$ & $1.72 \mathrm{E}-14$ & $<1 \mathrm{E}-10$ & $<1 \mathrm{E}-10$ \\
\hline Mo-99 & 25 & $2.28 \mathrm{E}-01$ & 1.15E-01 & $5.69 \mathrm{E}+00$ & $2.88 \mathrm{E}+00$ & $2.28 \mathrm{E}-03$ & $1.44 \mathrm{E}-03$ \\
\hline Os-194 & 1 & $2.28 \mathrm{E}-01$ & $1.15 \mathrm{E}-01$ & $2.28 \mathrm{E}-01$ & $1.15 \mathrm{E}-01$ & $9.10 \mathrm{E}-05$ & $5.75 \mathrm{E}-05$ \\
\hline$P-32^{(d)}$ & 5 & $0.00 \mathrm{E}+00$ & $0.00 \mathrm{E}+00$ & $0.00 \mathrm{E}+00$ & $0.00 \mathrm{E}+00$ & $0.00 \mathrm{E}+00$ & $0.00 \mathrm{E}+00$ \\
\hline P-33 ${ }^{(d)}$ & 3 & $0.00 \mathrm{E}+00$ & $0.00 \mathrm{E}+00$ & $0.00 \mathrm{E}+00$ & $0.00 \mathrm{E}+00$ & $0.00 \mathrm{E}+00$ & $0.00 \mathrm{E}+00$ \\
\hline Pd-103 & 5 & $2.36 \mathrm{E}-10$ & $1.20 \mathrm{E}-10$ & $1.18 \mathrm{E}-09$ & $5.98 \mathrm{E}-10$ & $<1 \mathrm{E}-10$ & $<1 \mathrm{E}-10$ \\
\hline Pt-195 & 5 & 5.95E-07 & $3.01 \mathrm{E}-07$ & $2.98 \mathrm{E}-06$ & $1.51 \mathrm{E}-06$ & $1.19 \mathrm{E}-09$ & $7.53 \mathrm{E}-10$ \\
\hline Re-186 & 10 & $2.28 \mathrm{E}-01$ & $1.15 \mathrm{E}-01$ & $2.28 \mathrm{E}+00$ & $1.15 \mathrm{E}+00$ & $9.10 \mathrm{E}-04$ & $5.75 \mathrm{E}-04$ \\
\hline Sc- 47 & 25 & 1.63E-15 & $8.26 \mathrm{E}-16$ & $4.08 \mathrm{E}-14$ & $2.07 \mathrm{E}-14$ & $<1 \mathrm{E}-10$ & $<1 \mathrm{E}-10$ \\
\hline
\end{tabular}


HNF-1844, Rev. 0

Table 32. Routine Air Transportation Impacts for Medical Isotope Shipments from Pasco, Wa. to Boston, Ma.

\begin{tabular}{|c|c|c|c|c|c|c|c|}
\hline \multirow[t]{2}{*}{ Isotope* } & \multirow{2}{*}{$\begin{array}{c}\begin{array}{c}\text { Number } \\
\text { of }\end{array} \\
\text { Shipments } \\
\text { per Year }\end{array}$} & \multicolumn{2}{|c|}{$\begin{array}{l}\text { Radiological Impacts } \\
\text { per Shipment }\end{array}$} & \multicolumn{2}{|c|}{$\begin{array}{l}\text { Annual Radiological } \\
\text { Impacts }\end{array}$} & \multicolumn{2}{|c|}{ Annual Health Effects } \\
\hline & & $\begin{array}{c}\text { Crew } \\
\text { (person- } \\
\text { rem/ } \\
\text { shipment) }\end{array}$ & $\begin{array}{c}\text { Public } \\
\text { (person- } \\
\text { rem/ } \\
\text { shipment) }\end{array}$ & $\begin{array}{c}\text { Crew } \\
\text { (person- } \\
\text { rem/year) }\end{array}$ & $\begin{array}{c}\text { Public } \\
\text { (person- } \\
\text { rem/year) }\end{array}$ & $\begin{array}{c}\text { Crew } \\
\text { (LCFs/ }^{\text {year) }}{ }^{(\mathrm{a})(\mathrm{b})}\end{array}$ & $\begin{array}{c}\text { Public } \\
(\text { LCFs/ } \\
\text { year) }^{(a)(b)}\end{array}$ \\
\hline $\mathrm{Se}-75$ & 1 & $5.72 \mathrm{E}-04$ & $2.90 \mathrm{E}-04$ & $5.72 \mathrm{E}-04$ & $2.90 \mathrm{E}-04$ & $2.29 \mathrm{E}-07$ & $1.45 \mathrm{E}-07$ \\
\hline $\mathrm{Sm}-145$ & 1 & $1.16 \mathrm{E}-03$ & $5.85 \mathrm{E}-04$ & $1.16 \mathrm{E}-03$ & $5.85 \mathrm{E}-04$ & $4.63 \mathrm{E}-07$ & $2.93 \mathrm{E}-07$ \\
\hline Sm-153 & 25 & 1.77E-03 & $8.94 \mathrm{E}-04$ & $4.42 \mathrm{E}-02$ & $2.24 \mathrm{E}-02$ & $1.77 \mathrm{E}-05$ & $1.12 \mathrm{E}-05$ \\
\hline Sn-117 & 5 & $1.07 \mathrm{E}-19$ & $5.43 \mathrm{E}-20$ & $5.37 \mathrm{E}-19$ & $2.71 \mathrm{E}-19$ & $<1 \mathrm{E}-10$ & $<1 \mathrm{E}-10$ \\
\hline Sr-85 & 1 & $6.37 \mathrm{E}-02$ & $3.22 \mathrm{E}-02$ & $6.37 \mathrm{E}-02$ & $3.22 \mathrm{E}-02$ & $2.55 \mathrm{E}-05$ & $1.61 \mathrm{E}-05$ \\
\hline Sr-89 & 3 & $1.79 \mathrm{E}-03$ & $9.03 \mathrm{E}-04$ & $4.46 \mathrm{E}-03$ & $2.26 \mathrm{E}-03$ & $1.79 \mathrm{E}-06$ & $1.13 \mathrm{E}-06$ \\
\hline Th-228 & 1 & $2.08 \mathrm{E}-09$ & $1.05 \mathrm{E}-09$ & $2.08 \mathrm{E}-09$ & $1.05 \mathrm{E}-09$ & $<1 \mathrm{E}-10$ & $<1 \mathrm{E}-10$ \\
\hline Th-229 & 1 & See Th-228 & See Th-228 & See Th-228 & See Th-228 & See Th-228 & $\begin{array}{c}\text { See Th- } \\
228\end{array}$ \\
\hline W-188 & 1 & $2.28 \mathrm{E}-01$ & $1.15 \mathrm{E}-01$ & $2.28 \mathrm{E}-01$ & $1.15 \mathrm{E}-01$ & $9.10 \mathrm{E}-05$ & $5.75 \mathrm{E}-05$ \\
\hline $\mathrm{Xe}-127$ & 3 & $2.00 \mathrm{E}-05$ & $1.01 \mathrm{E}-05$ & $4.99 \mathrm{E}-05$ & $2.52 \mathrm{E}-05$ & $2.00 \mathrm{E}-08$ & $1.26 \mathrm{E}-08$ \\
\hline Y-91 & 1 & $3.96 \mathrm{E}-02$ & $2.00 \mathrm{E}-02$ & $3.96 \mathrm{E}-02$ & $2.00 \mathrm{E}-02$ & $1.58 \mathrm{E}-05$ & $1.00 \mathrm{E}-05$ \\
\hline
\end{tabular}

(a) Calculated using the methodology prescribed in ICRP 60.

(b) Accident impacts are less than 1E-10 health effects; insignificant contributors to annual and life-cycle transportation impacts.

(c) Dose Factors for Os-194 were not included in the MICROSHIELD libraries; therefore, a TI of $13 \mathrm{mrem} / \mathrm{hr}$ was assumed.

(d) P-32 and P-33 do not emit gamma radiation; package shielding reduces dose rate to $0.0 \mathrm{mrem} / \mathrm{hr}$. 
HNF-1844, Rev. 0

Table 33. Routine Air Transportation Impacts for Medical Isotope Shipments from Pasco, Wa. to Chicago, Il.

\begin{tabular}{|c|c|c|c|c|c|c|c|}
\hline \multirow[t]{2}{*}{ Isotope } & \multirow{2}{*}{$\begin{array}{l}\text { Number of } \\
\text { Shipments } \\
\text { per Year }\end{array}$} & \multicolumn{2}{|c|}{$\begin{array}{l}\text { Radiological Impacts } \\
\text { per Shipment }\end{array}$} & \multicolumn{2}{|c|}{$\begin{array}{l}\text { Annual Radiological } \\
\text { Impacts }\end{array}$} & \multicolumn{2}{|c|}{ Annual Health Effects } \\
\hline & & $\begin{array}{c}\text { Crew } \\
\text { (person- } \\
\text { rem/ } \\
\text { shipment) }\end{array}$ & $\begin{array}{c}\text { Public } \\
\text { (person- } \\
\text { rem/ } \\
\text { shipment) }\end{array}$ & $\begin{array}{c}\text { Crew } \\
\text { (person- } \\
\text { rem/year) }\end{array}$ & $\begin{array}{c}\text { Public } \\
\text { (person- } \\
\text { rem/year) }\end{array}$ & $\begin{array}{c}\text { Crew } \\
(\text { LCFs/ } \\
\text { year })^{(a)(b)}\end{array}$ & $\begin{array}{c}\text { Public } \\
\text { (LCFs/ } \\
\text { year) }^{(a)(b)}\end{array}$ \\
\hline Ac-227 & 1 & $1.83 \mathrm{E}-09$ & $9.26 \mathrm{E}-10$ & $1.83 \mathrm{E}-09$ & $9.26 \mathrm{E}-10$ & $<1 \mathrm{E}-10$ & $<1 \mathrm{E}-10$ \\
\hline Au-198 & 25 & $3.45 \mathrm{E}-02$ & $1.74 \mathrm{E}-02$ & $8.61 \mathrm{E}-01$ & $4.36 \mathrm{E}-01$ & $3.45 \mathrm{E}-04$ & $2.18 \mathrm{E}-04$ \\
\hline Cd-109 & 1 & $5.69 \mathrm{E}-22$ & $2.88 \mathrm{E}-22$ & $5.69 \mathrm{E}-22$ & $2.88 \mathrm{E}-22$ & $<1 \mathrm{E}-10$ & $<1 \mathrm{E}-10$ \\
\hline $\mathrm{Cu}-64$ & 25 & $1.89 \mathrm{E}-02$ & $9.57 \mathrm{E}-03$ & 4.73E-01 & $2.39 \mathrm{E}-01$ & $1.89 \mathrm{E}-04$ & $1.20 \mathrm{E}-04$ \\
\hline $\mathrm{Cu}-67$ & 25 & $1.47 \mathrm{E}-10$ & 7.42E-11 & $3.67 \mathrm{E}-09$ & $1.86 \mathrm{E}-09$ & $<1 \mathrm{E}-10$ & $<1 \mathrm{E}-10$ \\
\hline Gd-153 & 1 & $3.92 \mathrm{E}-19$ & $1.98 \mathrm{E}-19$ & $3.92 \mathrm{E}-19$ & $1.98 \mathrm{E}-19$ & $<1 \mathrm{E}-10$ & $<1 \mathrm{E}-10$ \\
\hline Ho-166 & 25 & $1.20 \mathrm{E}-01$ & $6.06 \mathrm{E}-02$ & $3.00 \mathrm{E}+00$ & $1.52 \mathrm{E}+00$ & $1.20 \mathrm{E}-03$ & $7.58 \mathrm{E}-04$ \\
\hline I-125 & 1 & $6.48 \mathrm{E}-21$ & $3.28 \mathrm{E}-21$ & $6.48 \mathrm{E}-21$ & $3.28 \mathrm{E}-21$ & $<1 \mathrm{E}-10$ & $<1 \mathrm{E}-10$ \\
\hline $1-131$ & 10 & $8.46 \mathrm{E}-02$ & $4.28 \mathrm{E}-02$ & $8.46 \mathrm{E}-01$ & $4.28 \mathrm{E}-01$ & $3.38 \mathrm{E}-04$ & $2.14 \mathrm{E}-04$ \\
\hline Ir-192 & 1 & $2.00 \mathrm{E}-01$ & $1.01 \mathrm{E}-01$ & $2.00 \mathrm{E}-01$ & $1.01 \mathrm{E}-01$ & $8.00 \mathrm{E}-05$ & $5.06 \mathrm{E}-05$ \\
\hline Lu-177 & 10 & $2.98 \mathrm{E}-15$ & $1.51 \mathrm{E}-15$ & $2.98 \mathrm{E}-14$ & $1.51 \mathrm{E}-14$ & $<1 \mathrm{E}-10$ & $<1 \mathrm{E}-10$ \\
\hline Mo-99 & 25 & $2.00 \mathrm{E}-01$ & $1.01 \mathrm{E}-01$ & $5.00 \mathrm{E}+00$ & $2.53 \mathrm{E}+00$ & $2.00 \mathrm{E}-03$ & $1.26 \mathrm{E}-03$ \\
\hline Os- $194^{(\mathrm{c})}$ & 1 & $2.00 \mathrm{E}-01$ & $1.01 \mathrm{E}-01$ & $2.00 \mathrm{E}-01$ & $1.01 \mathrm{E}-01$ & $8.00 \mathrm{E}-05$ & $5.06 \mathrm{E}-05$ \\
\hline $\mathrm{P}-32^{(\infty)}$ & 5 & $0.00 \mathrm{E}+00$ & $0.00 \mathrm{E}+00$ & $0.00 \mathrm{E}+00$ & $0.00 \mathrm{E}+00$ & $0.00 \mathrm{E}+00$ & $0.00 \mathrm{E}+00$ \\
\hline$P-33^{(d)}$ & 3 & $0.00 \mathrm{E}+00$ & $0.00 \mathrm{E}+00$ & $0.00 \mathrm{E}+00$ & $0.00 \mathrm{E}+00$ & $0.00 \mathrm{E}+00$ & $0.00 \mathrm{E}+00$ \\
\hline Pd-103 & 5 & $2.08 \mathrm{E}-10$ & $1.05 \mathrm{E}-10$ & $1.04 \mathrm{E}-09$ & $5.25 \mathrm{E}-10$ & $<$ IE- 10 & $<1 \mathrm{E}-10$ \\
\hline Pt-195m & 5 & $5.23 \mathrm{E}-07$ & $2.65 \mathrm{E}-07$ & $2.61 \mathrm{E}-06$ & $1.32 \mathrm{E}-06$ & $1.05 \mathrm{E}-09$ & $6.61 \mathrm{E}-10$ \\
\hline Re-186 & 10 & $2.00 \mathrm{E}-01$ & $1.01 \mathrm{E}-01$ & $2.00 \mathrm{E}+00$ & $1.01 \mathrm{E}+00$ & $8.00 \mathrm{E}-04$ & $5.06 \mathrm{E}-04$ \\
\hline Sc-47 & 25 & $1.44 \mathrm{E}-15$ & $7.26 \mathrm{E}-16$ & $3.59 \mathrm{E}-14$ & $1.81 \mathrm{E}-14$ & $<1 \mathrm{E}-10$ & $<1 \mathrm{E}-10$ \\
\hline $\mathrm{Se}-75$ & 1 & $5.03 \mathrm{E}-04$ & $2.54 \mathrm{E}-04$ & $5.03 \mathrm{E}-04$ & $2.54 \mathrm{E}-04$ & $2.01 \mathrm{E}-07$ & $1.27 \mathrm{E}-07$ \\
\hline $\mathrm{Sm}-145$ & 1 & $1.02 \mathrm{E}-03$ & $5.14 \mathrm{E}-04$ & $1.02 \mathrm{E}-03$ & 5.14E-04 & $4.07 \mathrm{E}-07$ & $2.57 \mathrm{E}-07$ \\
\hline $\mathrm{Sm}-153$ & 25 & $1.55 \mathrm{E}-03$ & $7.86 \mathrm{E}-04$ & $3.88 \mathrm{E}-02$ & $1.96 \mathrm{E}-02$ & $1.55 \mathrm{E}-05$ & $9.82 \mathrm{E}-06$ \\
\hline
\end{tabular}


HNF-1844, Rev. 0

Table 33. Routine Air Transportation Impacts for Medical Isotope Shipments from Pasco, Wa. to Chicago, Il.

\begin{tabular}{|c|c|c|c|c|c|c|c|}
\hline \multirow[t]{2}{*}{ Isotope } & \multirow{2}{*}{$\begin{array}{l}\text { Number of } \\
\text { Shipments } \\
\text { per Year }\end{array}$} & \multicolumn{2}{|c|}{$\begin{array}{c}\text { Radiological Impacts } \\
\text { per Shipment }\end{array}$} & \multicolumn{2}{|c|}{$\begin{array}{c}\text { Annual Radiological } \\
\text { Impacts }\end{array}$} & \multicolumn{2}{|c|}{ Annual Health Effects } \\
\hline & & $\begin{array}{c}\text { Crew } \\
\text { (person- } \\
\text { rem/ } \\
\text { shipment) }\end{array}$ & $\begin{array}{c}\text { Public } \\
\text { (person- } \\
\text { rem/ } \\
\text { shipment) }\end{array}$ & $\begin{array}{c}\text { Crew } \\
\text { (person- } \\
\text { rem/year) }\end{array}$ & $\begin{array}{c}\text { Public } \\
\text { (person- } \\
\text { rem/year) }\end{array}$ & 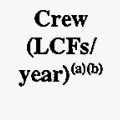 & $\begin{array}{l}\text { Public } \\
\text { (LCFs/ } \\
\text { year) }^{(a)(b)}\end{array}$ \\
\hline Sn-117m & 5 & $9.43 \mathrm{E}-20$ & $4.77 \mathrm{E}-20$ & $4.71 \mathrm{E}-19$ & $2.38 \mathrm{E}-19$ & $<1 \mathrm{E}-10$ & $<1 \mathrm{E}-10$ \\
\hline $\mathrm{Sr}-85$ & 1 & $5.60 \mathrm{E}-02$ & $2.83 \mathrm{E}-02$ & $5.60 \mathrm{E}-02$ & $2.83 \mathrm{E}-02$ & $2.24 \mathrm{E}-05$ & $1.42 \mathrm{E}-05$ \\
\hline Sr-89 & 3 & $1.57 \mathrm{E}-03$ & $7.94 \mathrm{E}-04$ & $3.92 \mathrm{E}-03$ & $1.98 \mathrm{E}-03$ & $1.57 \mathrm{E}-06$ & $9.92 \mathrm{E}-07$ \\
\hline Th-228 & 1 & $1.83 \mathrm{E}-09$ & $9.26 \mathrm{E}-10$ & $1.83 \mathrm{E}-09$ & $9.26 \mathrm{E}-10$ & $<1 \mathrm{E}-10$ & $<1 \mathrm{E}-10$ \\
\hline Th-229 & 1 & See Th-228 & See $T h-228$ & See Th- 228 & See Th-228 & See Th-228 & $\begin{array}{l}\text { See Th- } \\
228\end{array}$ \\
\hline $\mathrm{W}-188$ & 1 & $2.00 \mathrm{E}-01$ & $1.01 \mathrm{E}-01$ & $2.00 \mathrm{E}-01$ & $1.01 \mathrm{E}-01$ & $8.00 \mathrm{E}-05$ & $5.06 \mathrm{E}-05$ \\
\hline $\mathrm{Xe}-127$ & 3 & $1.75 \mathrm{E}-05$ & $8.87 \mathrm{E}-06$ & $4.38 \mathrm{E}-05$ & $2.22 \mathrm{E}-05$ & $1.75 \mathrm{E}-08$ & 1.11E-08 \\
\hline $\mathrm{Y}-91$ & 1 & $3.48 \mathrm{E}-02$ & $1.76 \mathrm{E}-02$ & $3.48 \mathrm{E}-02$ & $1.76 \mathrm{E}-02$ & $1.39 \mathrm{E}-05$ & $8.79 \mathrm{E}-06$ \\
\hline
\end{tabular}

(a) Calculated using the methodology prescribed in ICRP 60

(b) Accident impacts are less than $1 \mathrm{E}-10$ health effects; insignificant contributors to annual and life-cycle transportation impacts.

(c) Dose Factors for Os-194 were not included in the MICROSHIELD libraries; therefore, a Tl of $13 \mathrm{mrem} / \mathrm{hr}$ was assumed.

(d) P-32 and P-33 do not emit gamma radiation; package shielding reduces dose rate to $0.0 \mathrm{mrem} / \mathrm{hr}$. 
HNF-1844, Rev. 0

Table 34. Routine Air Transportation Impacts for Medical Isotope Shipments from Pasco, Wa. to St. Louis, Mo.

\begin{tabular}{|c|c|c|c|c|c|c|c|}
\hline \multirow[t]{2}{*}{ Isotope* } & \multirow{2}{*}{$\begin{array}{l}\text { Number } \\
\text { of } \\
\text { Shipments } \\
\text { per Year }\end{array}$} & \multicolumn{2}{|c|}{$\begin{array}{c}\text { Radiological Impacts } \\
\text { per Shipment }\end{array}$} & \multicolumn{2}{|c|}{$\begin{array}{l}\text { Annual Radiological } \\
\text { Impacts }\end{array}$} & \multicolumn{2}{|c|}{ Annual Health Effects } \\
\hline & & $\begin{array}{c}\text { Crew } \\
\text { (person- } \\
\text { rem/ } \\
\text { shipment) }\end{array}$ & $\begin{array}{c}\text { Public } \\
\text { (person- } \\
\text { rem/ } \\
\text { shipment) }\end{array}$ & $\begin{array}{c}\text { Crew } \\
\text { (person- } \\
\text { rem/ year) }\end{array}$ & $\begin{array}{c}\text { Public } \\
\text { (person- } \\
\text { rem/ year) }\end{array}$ & $\begin{array}{c}\text { Crew } \\
(\text { LCFs/ } \\
\text { year) }^{(a)(b)}\end{array}$ & $\begin{array}{c}\text { Public } \\
(\text { LCFs/ } \\
\text { year })^{(a)(b)}\end{array}$ \\
\hline Ac-227 & 1 & $1.80 \mathrm{E}-09$ & $9.10 \mathrm{E}-10$ & $1.80 \mathrm{E}-09$ & $9.10 \mathrm{E}-10$ & $<1 \mathrm{E}-10$ & $<1 \mathrm{E}-10$ \\
\hline Au-198 & 25 & $3.39 \mathrm{E}-02$ & $1.71 \mathrm{E}-02$ & $8.47 \mathrm{E}-01$ & $4.28 \mathrm{E}-01$ & $3.39 \mathrm{E}-04$ & $2.14 \mathrm{E}-04$ \\
\hline Cd-109 & 1 & $5.59 \mathrm{E}-22$ & $2.83 \mathrm{E}-22$ & $5.59 \mathrm{E}-22$ & $2.83 \mathrm{E}-22$ & $<1 \mathrm{E}-10$ & $<1 E-10$ \\
\hline $\mathrm{Cu}-64$ & 25 & $1.86 \mathrm{E}-02$ & $9.41 \mathrm{E}-03$ & $4.65 \mathrm{E}-01$ & $2.35 \mathrm{E}-01$ & $1.86 \mathrm{E}-04$ & $1.18 \mathrm{E}-04$ \\
\hline $\mathrm{Cu}-67$ & 25 & $1.44 \mathrm{E}-10$ & $7.30 \mathrm{E}-11$ & $3.61 \mathrm{E}-09$ & $1.82 \mathrm{E}-09$ & $<1 \mathrm{E}-10$ & $<1 \mathrm{E}-10$ \\
\hline Gd-153 & 1 & $3.86 \mathrm{E}-19$ & $1.95 \mathrm{E}-19$ & $3.86 \mathrm{E}-19$ & $1.95 \mathrm{E}-19$ & $<1 \mathrm{E}-10$ & $<1 \mathrm{E}-10$ \\
\hline Нo-166 & 25 & $1.18 \mathrm{E}-01$ & $5.96 \mathrm{E}-02$ & $2.94 \mathrm{E}+00$ & $1.49 \mathrm{E}+00$ & $1.18 \mathrm{E}-03$ & $7.45 \mathrm{E}-04$ \\
\hline $\mathrm{I}-125$ & 1 & $6.37 \mathrm{E}-21$ & $3.22 \mathrm{E}-21$ & $6.37 \mathrm{E}-21$ & $3.22 \mathrm{E}-21$ & $<1 \mathrm{E}-10$ & $<1 \mathrm{E}-10$ \\
\hline $\mathrm{I}-131$ & 10 & $8.32 \mathrm{E}-02$ & $4.21 \mathrm{E}-02$ & $8.32 \mathrm{E}-01$ & $4.21 \mathrm{E}-01$ & 3.33E-04 & 2.10E-04: \\
\hline Ir -192 & 1 & $1.97 \mathrm{E}-01$ & $9.94 \mathrm{E}-02$ & $1.97 \mathrm{E}-01$ & $9.94 \mathrm{E}-02$ & $7.86 \mathrm{E}-05$ & $4.97 \mathrm{E}-05$ \\
\hline Lu-177 & 10 & $2.93 \mathrm{E}-15$ & $1.48 \mathrm{E}-15$ & $2.93 \mathrm{E}-14$ & $1.48 \mathrm{E}-14$ & $<1 E-10$ & $<1 \mathrm{E}-10$ \\
\hline Mo-99 & 25 & $1.97 \mathrm{E}-01$ & $9.94 \mathrm{E}-02$ & $4.91 \mathrm{E}+00$ & $2.49 \mathrm{E}+00$ & $1.97 \mathrm{E}-03$ & $1.24 \mathrm{E}-03$ \\
\hline Os-194 & 1 & $1.97 \mathrm{E}-01$ & $9.94 \mathrm{E}-02$ & $1.97 \mathrm{E}-01$ & $9.94 \mathrm{E}-02$ & $7.86 \mathrm{E}-05$ & $4.97 \mathrm{E}-05$ \\
\hline$P-32^{(d)}$ & 5 & $0.00 \mathrm{E}+00$ & $0.00 \mathrm{E}+00$ & $0.00 \mathrm{E}+00$ & $0.00 \mathrm{E}+00$ & $0.00 \mathrm{E}+00$ & $0.00 \mathrm{E}+00$ \\
\hline P-33 (d) & 3 & $0.00 \mathrm{E}+00$ & $0.00 \mathrm{E}+00$ & $0.00 \mathrm{E}+00$ & $0.00 \mathrm{E}+00$ & $0.00 \mathrm{E}+00$ & $0.00 \mathrm{E}+00$ \\
\hline Pd-103 & 5 & $2.04 \mathrm{E}-10$ & $1.03 \mathrm{E}-10$ & $1.02 \mathrm{E}-09$ & $5.16 \mathrm{E}-10$ & $<1 \mathrm{E}-10$ & $<1 \mathrm{E}-10$ \\
\hline Pt-195 & 5 & $5.14 \mathrm{E}-07$ & $2.60 \mathrm{E}-07$ & $2.57 \mathrm{E}-06$ & $1.30 \mathrm{E}-06$ & $1.03 \mathrm{E}-09$ & $6.50 \mathrm{E}-10$ \\
\hline $\operatorname{Re}-186$ & 10 & $1.97 \mathrm{E}-01$ & $9.94 \mathrm{E}-02$ & $1.97 \mathrm{E}+00$ & $9.94 \mathrm{E}-01$ & $7.86 \mathrm{E}-04$ & $4.97 \mathrm{E}-04$ \\
\hline Sc-47 & 25 & $1.41 \mathrm{E}-15$ & $7.14 \mathrm{E}-16$ & $3.53 \mathrm{E}-14$ & $1.78 \mathrm{E}-14$ & $<1 \mathrm{E}-10$ & $<1 E-10$ \\
\hline $\mathrm{Se}-75$ & 1 & $4.94 \mathrm{E}-04$ & $2.50 \mathrm{E}-04$ & $4.94 \mathrm{E}-04$ & $2.50 \mathrm{E}-04$ & $1.98 \mathrm{E}-07$ & $1.25 \mathrm{E}-07$ \\
\hline Sm-145 & 1 & $9.99 \mathrm{E}-04$ & $5.06 \mathrm{E}-04$ & $9.99 \mathrm{E}-04$ & $5.06 \mathrm{E}-04$ & $4.00 \mathrm{E}-07$ & $2.53 \mathrm{E}-07$ \\
\hline Sm-153 & 25 & $1.53 \mathrm{E}-03$ & $7.72 \mathrm{E}-04$ & $3.82 \mathrm{E}-02$ & $1.93 \mathrm{E}-02$ & $1.53 \mathrm{E}-05$ & $9.66 \mathrm{E}-06$ \\
\hline
\end{tabular}


HINF-1844, Rev. 0

Table 34. Routine Air Transportation Impacts for Medical Isotope Shipments from Pasco, Wa. to St. Louis, Mo.

\begin{tabular}{|c|c|c|c|c|c|c|c|}
\hline \multirow[t]{2}{*}{ Isotope* } & \multirow{2}{*}{$\begin{array}{l}\text { Number } \\
\text { of } \\
\text { Shipments } \\
\text { per Year }\end{array}$} & \multicolumn{2}{|c|}{$\begin{array}{l}\text { Radiological Impacts } \\
\text { per Shipment }\end{array}$} & \multicolumn{2}{|c|}{$\begin{array}{c}\text { Annual Radiological } \\
\text { Impacts }\end{array}$} & \multicolumn{2}{|c|}{ Annual Health Effects } \\
\hline & & $\begin{array}{c}\text { Crew } \\
\text { (person- } \\
\text { rem/ } \\
\text { shipment) }\end{array}$ & $\begin{array}{c}\text { Public } \\
\text { (person- } \\
\text { rem/ } \\
\text { shipment) }\end{array}$ & $\begin{array}{c}\text { Crew } \\
\text { (person- } \\
\text { rem/ year) }\end{array}$ & $\begin{array}{c}\text { Public } \\
\text { (person- } \\
\text { rem/ year) }\end{array}$ & 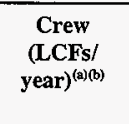 & 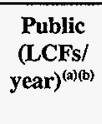 \\
\hline Sn-117 & 5 & $9.27 \mathrm{E}-20$ & $4.69 \mathrm{E}-20$ & $4.63 \mathrm{E}-19$ & $2.34 \mathrm{E}-19$ & $<1 \mathrm{E}-10$ & $<1 \mathrm{E}-10$ \\
\hline $\mathrm{Sr}-85$ & 1 & $5.50 \mathrm{E}-02$ & $2.78 \mathrm{E}-02$ & $5.50 \mathrm{E}-02$ & $2.78 \mathrm{E}-02$ & $2.20 \mathrm{E}-05$ & $1.39 \mathrm{E}-05$ \\
\hline $\mathrm{Sr}-89$ & 3 & $1.54 \mathrm{E}-03$ & $7.80 \mathrm{E}-04$ & $3.86 \mathrm{E}-03$ & $1.95 \mathrm{E}-03$ & $1.54 \mathrm{E}-06$ & $9.75 \mathrm{E}-07$ \\
\hline Th-228 & 1 & $1.80 \mathrm{E}-09$ & $9.10 \mathrm{E}-10$ & $1.80 \mathrm{E}-09$ & $9.10 \mathrm{E}-10$ & $<1 \mathrm{E}-10$ & $<1 \mathrm{E}-10$ \\
\hline Th-229 & 1 & See Th-228 & See Th-228 & See Th-228 & See Th-228 & See Th-228 & $\begin{array}{l}\text { See Th- } \\
228\end{array}$ \\
\hline W-188 & 1 & $1.97 \mathrm{E}-01$ & $9.94 \mathrm{E}-02$ & $1.97 \mathrm{E}-01$ & $9.94 \mathrm{E}-02$ & $7.86 \mathrm{E}-05$ & $4.97 \mathrm{E}-05$ \\
\hline $\mathrm{Xe}-127$ & 3 & $1.72 \mathrm{E}-05$ & $8.72 \mathrm{E}-06$ & $4.31 \mathrm{E}-05$ & $2.18 \mathrm{E}-05$ & $1.72 \mathrm{E}-08$ & $1.09 \mathrm{E}-08$ \\
\hline $\mathrm{Y}-91$ & 1 & $3.42 \mathrm{E}-02$ & $1.73 \mathrm{E}-02$ & $3.42 \mathrm{E}-02$ & $1.73 \mathrm{E}-02$ & $1.37 \mathrm{E}-05$ & $8.64 \mathrm{E}-06$ \\
\hline
\end{tabular}

(a) Calculated using the methodology prescribed in ICRP 60

(b) Accident impacts are less than $1 \mathrm{E}-10$ health effects; insignificant contributors to annual and life-cycle transportation impacts.

(c) Dose Factors for Os-194 were not included in the MICROSHIELD libraries; therefore, a TI of $13 \mathrm{mrem} / \mathrm{hr}$ was assumed.

(d) P-32 and P-33 do not emit gamma radiation; package shielding reduces dose rate to $0.0 \mathrm{mrem} / \mathrm{hr}$.

\subsubsection{Summary of Radiological Routine or Incident Free Transportation Impacts.}

The routine or incident free radiological transportation impacts for the production, separation, and distribution of an isotope is the summation of the truck and air transportation impacts (see Table 35). The results in the table represent the sum of the impacts of shipping irradiated targets by truck from FFTF to the 325 Building, separated isotopes by truck from the 325 Building to the Tri-Cities Airport, separated isotopes by air from the Tri-Cities Airport to destination airports near the pharmaceutical distributors, and truck shipments from the destination airports to the nearby pharmaceutical distributors. It was observed that the summed exposures for each isotope shipment are dominated by the air transport legs. This is primarily because the truck legs are a few percent of the total one-way distance traveled. 
Table 35. Summary of Routine or Incident Free Transportation Impacts ${ }^{(\mathrm{a})(\mathrm{b})}$

\begin{tabular}{|c|c|c|c|c|c|c|c|}
\hline \multirow[t]{3}{*}{ Isotope* } & \multirow{3}{*}{$\begin{array}{c}\text { Number } \\
\text { of } \\
\text { Shipments } \\
\text { per Year }\end{array}$} & \multicolumn{6}{|c|}{$\begin{array}{l}\text { Summary of Annual Health Effects Associated with Truck and Air } \\
\text { Transport to Pharmaceutical Distributors (LCFs/year) }\end{array}$} \\
\hline & & \multicolumn{2}{|c|}{ DuPont } & \multicolumn{2}{|c|}{ Amersham } & \multicolumn{2}{|c|}{ Malinckrodt } \\
\hline & & 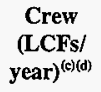 & 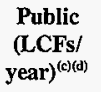 & $\begin{array}{c}\text { Crew } \\
(\text { LCFs/ } \\
\text { year) })^{(\mathbf{c})(d)}\end{array}$ & $\begin{array}{c}\text { Public } \\
\text { (LCFs/ } \\
\text { year) }^{(\mathbf{c})(d)}\end{array}$ & $\begin{array}{c}\text { Crew } \\
\text { (LCFs/ }^{\text {year })^{(c)(d)}}\end{array}$ & 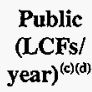 \\
\hline Ac-227 & 1 & $6.5 \mathrm{E}-10$ & $<1 \mathrm{E}-10$ & $6.5 \mathrm{E}-10$ & $<1 \mathrm{E}-10$ & $6.5 \mathrm{E}-10$ & $<1 \mathrm{E}-10$ \\
\hline $\mathrm{Au}-198$ & 25 & $3.9 \mathrm{E}-04$ & $2.5 \mathrm{E}-04$ & $3.5 \mathrm{E}-04$ & 2.2E-04 & $3.4 \mathrm{E}-04$ & $2.1 \mathrm{E}-04$ \\
\hline Cd-109 & 1 & $7.6 \mathrm{E}-10$ & $<1 \mathrm{E}-10$ & $7.6 \mathrm{E}-10$ & $<1 \mathrm{E}-10$ & $7.6 \mathrm{E}-10$ & $<1 \mathrm{E}-10$ \\
\hline $\mathrm{Cu}-64$ & 25 & $2.2 \mathrm{E}-04$ & $1.4 \mathrm{E}-04$ & $1.9 \mathrm{E}-04$ & $1.2 \mathrm{E}-04$ & $1.9 \mathrm{E}-04$ & 1.2E-04 \\
\hline $\mathrm{Cu}-67$ & 25 & $2.5 \mathrm{E}-08$ & $1.5 \mathrm{E}-09$ & $2.5 \mathrm{E}-08$ & $1.5 \mathrm{E}-09$ & $2.5 \mathrm{E}-08$ & $1.5 \mathrm{E}-09$ \\
\hline Gd- 153 & 1 & $5.1 \mathrm{E}-08$ & $3.1 \mathrm{E}-09$ & $5.1 \mathrm{E}-08$ & 3.1E-09 & $5.1 \mathrm{E}-08$ & 3.1E-09 \\
\hline Ho-166 & 25 & $1.4 \mathrm{E}-03$ & $8.6 \mathrm{E}-04$ & $1.2 \mathrm{E}-03$ & 7.6E-04 & $1.2 \mathrm{E}-03$ & $7.5 \mathrm{E}-04$ \\
\hline I-125 & 1 & $6.8 \mathrm{E}-10$ & $<1 \mathrm{E}-10$ & $6.8 \mathrm{E}-10$ & $<1 \mathrm{E}-10$ & $6.8 \mathrm{E}-10$ & $<1 \mathrm{E}-10$ \\
\hline $\mathrm{I}-131$ & 10 & $3.9 \mathrm{E}-04$ & $2.4 \mathrm{E}-04$ & $3.4 \mathrm{E}-04$ & $2.1 \mathrm{E}-04$ & 3.3E-04 & 2.1E-04 \\
\hline $\operatorname{Ir}-192$ & 1 & $9.1 \mathrm{E}-05$ & $5.8 \mathrm{E}-05$ & $8.0 \mathrm{E}-05$ & $5.1 \mathrm{E}-05$ & $7.9 \mathrm{E}-05$ & 5.0E-05 \\
\hline Lu-177 & 10 & $6.5 \mathrm{E}-09$ & $3.9 \mathrm{E}-10$ & $6.5 \mathrm{E}-09$ & $3.9 \mathrm{E}-10$ & $6.5 \mathrm{E}-09$ & $3.9 \mathrm{E}-10$ \\
\hline Mo-99 & 25 & $2.3 \mathrm{E}-03$ & $1.4 \mathrm{E}-03$ & $2.0 \mathrm{E}-03$ & $1.3 \mathrm{E}-03$ & $2.0 \mathrm{E}-03$ & $1.2 \mathrm{E}-03$ \\
\hline Os-194 & 1 & $9.1 \mathrm{E}-05$ & $5.8 \mathrm{E}-05$ & $8.0 \mathrm{E}-05$ & $5.1 \mathrm{E}-05$ & $7.9 \mathrm{E}-05$ & $5.0 \mathrm{E}-05$ \\
\hline $\mathrm{P}-32$ & 5 & $5.0 \mathrm{E}-09$ & $3.0 \mathrm{E}-10$ & $5.0 \mathrm{E}-09$ & $3.0 \mathrm{E}-10$ & $5.0 \mathrm{E}-09$ & $3.0 \mathrm{E}-10$ \\
\hline P-33 & 3 & $2.5 \mathrm{E}-09$ & $1.5 \mathrm{E}-10$ & $2.5 \mathrm{E}-09$ & $1.5 \mathrm{E}-10$ & $2.5 \mathrm{E}-09$ & 1.5E-10 \\
\hline Pd-103 & 5 & $5.0 \mathrm{E}-09$ & $3.0 \mathrm{E}-10$ & $5.0 \mathrm{E}-09$ & $3.0 \mathrm{E}-10$ & $5.0 \mathrm{E}-09$ & $3.0 \mathrm{E}-10$ \\
\hline Pt-195m & 5 & 4.4E-09 & $9.5 \mathrm{E}-10$ & $4.3 \mathrm{E}-09$ & $8.6 \mathrm{E}-10$ & 4.3E-09 & $8.5 \mathrm{E}-10$ \\
\hline $\operatorname{Re}-186$ & 10 & $9.1 \mathrm{E}-04$ & $5.8 \mathrm{E}-04$ & $8.0 \mathrm{E}-04$ & 5.1E-04 & $7.9 \mathrm{E}-04$ & $5.0 \mathrm{E}-04$ \\
\hline Sc- 47 & 25 & $2.5 \mathrm{E}-08$ & $1.5 \mathrm{E}-09$ & $2.5 \mathrm{E}-08$ & $1.5 \mathrm{E}-09$ & $2.5 \mathrm{E}-08$ & $1.5 \mathrm{E}-09$ \\
\hline Se-75 & 1 & $2.3 \mathrm{E}-07$ & $1.5 \mathrm{E}-07$ & $2.0 \mathrm{E}-07$ & $1.3 \mathrm{E}-07$ & $2.0 \mathrm{E}-07$ & 1.3E-07 \\
\hline Sm-145 & 1 & $4.6 \mathrm{E}-07$ & $2.9 \mathrm{E}-07$ & $4.1 \mathrm{E}-07$ & $2.6 \mathrm{E}-07$ & $4.0 \mathrm{E}-07$ & 2.5E-07 \\
\hline Sm-153 & 25 & $1.8 \mathrm{E}-05$ & $1.1 \mathrm{E}-05$ & $1.6 \mathrm{E}-05$ & $9.8 \mathrm{E}-06$ & $1.5 \mathrm{E}-05$ & $9.7 \mathrm{E}-06$ \\
\hline
\end{tabular}


HNF-1844, Rev. 0

Table 35. Summary of Routine or Incident Free Transportation Impacts ${ }^{(a)(b)}$

\begin{tabular}{|c|c|c|c|c|c|c|c|}
\hline \multirow[t]{3}{*}{ Isotope* } & \multirow{3}{*}{$\begin{array}{c}\text { Number } \\
\text { of } \\
\text { Shipments } \\
\text { per Year }\end{array}$} & \multicolumn{6}{|c|}{$\begin{array}{l}\text { Summary of Annual Health Effects Associated with Truck and Air } \\
\text { Transport to Pharmaceutical Distributors (LCFs/year) }\end{array}$} \\
\hline & & \multicolumn{2}{|c|}{ DuPont } & \multicolumn{2}{|c|}{ Amersham } & \multicolumn{2}{|c|}{ Malinckrodt } \\
\hline & & 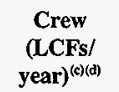 & 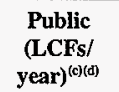 & 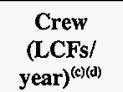 & $\begin{array}{c}\text { Public } \\
\text { (LCFs/ } \\
\text { year) }^{(\mathbf{c})(d)}\end{array}$ & $\begin{array}{c}\text { Crew } \\
(\text { LCFs/ } \\
\text { year) }^{(c)(d)}\end{array}$ & 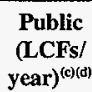 \\
\hline $\mathrm{Sn}-117 \mathrm{~m}$ & 5 & $5.0 \mathrm{E}-09$ & $3.0 \mathrm{E}-10$ & $5.0 \mathrm{E}-09$ & $3.0 \mathrm{E}-10$ & 5.0E-09 & $3.0 \mathrm{E}-10$ \\
\hline $\mathrm{Sr}-85$ & 1 & $2.6 \mathrm{E}-05$ & $1.6 \mathrm{E}-05$ & 2.2E-0S & $1.4 \mathrm{E}-05$ & $2.2 \mathrm{E}-05$ & $1.4 \mathrm{E}-05$ \\
\hline Sr-89 & 3 & $1.8 \mathrm{E}-06$ & $1.1 \mathrm{E}-06$ & $1.6 \mathrm{E}-06$ & $9.9 \mathrm{E}-07$ & $1.5 \mathrm{E}-06$ & $9.8 \mathrm{E}-07$ \\
\hline Th-228 & 1 & $6.5 \mathrm{E}-10$ & $<1 \mathrm{E}-10$ & $6.5 \mathrm{E}-10$ & $<1 \mathrm{E}-10$ & $6.5 \mathrm{E}-10$ & $<1 \mathrm{E}-10$ \\
\hline Th-229 & 1 & See $\operatorname{Th}-228$ & See Th-228 & See Th-228 & See Th-228 & See Th-228 & $\begin{array}{c}\text { See } \\
\text { Th-228 }\end{array}$ \\
\hline W-188 & 1 & $9.1 \mathrm{E}-05$ & $5.8 \mathrm{E}-05$ & $8.0 \mathrm{E}-05$ & $5.1 \mathrm{E}-05$ & $7.9 \mathrm{E}-05$ & $5.0 \mathrm{E}-05$ \\
\hline $\mathrm{Xe}-127$ & 3 & $2.2 \mathrm{E}-08$ & $1.3 \mathrm{E}-08$ & $2.0 \mathrm{E}-08$ & $1.1 \mathrm{E}-08$ & $2.0 \mathrm{E}-08$ & $1.1 \mathrm{E}-08$ \\
\hline$Y-91$ & 1 & $1.6 \mathrm{E}-05$ & $1.0 \mathrm{E}-05$ & $1.4 \mathrm{E}-05$ & $8.8 \mathrm{E}-06$ & $1.4 \mathrm{E}-05$ & 8.7E-06 \\
\hline
\end{tabular}

(a) See Tables 27 through 34 for radiological impacts 2.0E-07 LCFs/year for the crew and public, respectively.

(c) Calculated using the methodology prescribed in ICRP 60 .

(d) Accident impacts are less than 1E-10 health effects; insignificant contributors to annual and life-cycle transportation impacts.

Comparisons to the radiation exposures received from natural background radiation were developed to place the calculated routine doses from transportation of medical isotopes in perspective. The RADTRAN 4 computer code integrates population exposures out to $400 \mathrm{~m}$ on either side of a highway or a strip $800 \mathrm{~m}$ wide along the entire trip length. This can be used to calculate the affected area along a particular transportation corridor. The number of potentially-exposed persons in this area was calculated by summing the products of the transport distance through rural, suburban, and urban population zones, the transport corridor width $(0.8 \mathrm{~km})$, and population density in each respective population zone. The resulting number of potentially-affected persons was then multiplied by the average annual effective dose equivalent from natural background radiation, including cosmic, terrestrial, inhaled, and in-the-body sources, to calculate the average annual natural background exposures to the population that is potentially-affected by the medical isotope shipments. The average individual exposure to natural background radiation in the United States is $300 \mathrm{mrem} / \mathrm{yr}$ (NCRP 1987). The resulting natural background exposures are directly comparable to the 
annual integrated population doses received from medical isotope shipments. The calculated natural background exposures are:

- The 325 Building to Tri-Cities Airport: 1000 person-rem/yr (0.5 LCFs/yr)

- Chicago Airport to Amersham: 13,000 person-rem/yr (6 LCFs/yr)

- Boston Airport to DuPont: 9,000 person-rem/yr (5 LCFs/yr)

- St. Louis Airport to Malinckrodt: 4000 person-rem/yr (2 LCFs/yr).

These estimates were developed for the truck transport links and do not include exposures to medical isotope shipments or natural background exposures to persons on aircraft during the air transport segments. However, the estimated health effects from natural background radiation to persons exposed along the truck transport corridor are significantly greater than the health effects associated with the combined truck and air shipments of medical isotopes shown in Table 35.

5.2.2 Non-Radiological Impacts due to Incident-Free Transportation Activities. Impacts to the public from non-radiological causes were also evaluated. This included fatalities resulting from fugitive emissions or pollutants emitted from the vehicles during normal transportation. Based on the information contained in Rao et al. (1982), the types of pollutants that are present and can impact the public are sulfur oxides $\left(\mathrm{SO}_{\mathrm{x}}\right)$, particulates, nitrogen oxides $\left(\mathrm{NO}_{x}\right)$, carbon monoxide $(\mathrm{CO})$, hydrocarbons $(\mathrm{HC})$, and photochemical oxidants $\left(\mathrm{O}_{x}\right)$. Of these pollutants, Rao et al. (1982) determined that the majority of the health effects are due to $\mathrm{SO}_{\mathrm{x}}$ and the particulates. Unit risk factors (fatalities per kilometer) for truck shipments were developed by Rao et al. (1982) for travel in urban population zones. The unit risk factor is $1.0 \mathrm{E}-07$ fatalities $/ \mathrm{km}$ for truck shipments. 
HNF-1844, Rev. 0

The nonradiological incident-free impacts were calculated based on the travel distances shown in Table 5. The results are shown in Table 30.

Table 36. Nonradiological Impacts due to Routine or Incident Free Transportation

\begin{tabular}{|l|l|}
\hline \multicolumn{1}{|c|}{ Transportation Segment } & \multicolumn{1}{|c|}{$\begin{array}{c}\text { Estimated } \\
\text { Fatalities/Year } \\
\text { (public) }\end{array}$} \\
\hline Target material from ORNL to the 300 Area ${ }^{(0)}$ & $1.2 \mathrm{E}-04$ \\
\hline Unirradiated targets from the 300 Area to FFTF(c) & $1.5 \mathrm{E}-06$ \\
\hline Irradiated targets from FFTF to the 325 Building ${ }^{(c)}$ & $1.5 \mathrm{E}-06$ \\
\hline Isotope products from 325 Building to Pasco Airport & $2.5 \mathrm{E}-05$ \\
\hline $\begin{array}{l}\text { Isotope products from destination Airport to Distributor (maximum } \\
\text { consequence) }\end{array}$ & $4.3 \mathrm{E}-04$ \\
\hline Solid and liquid waste from the 300 Area to 200 East Area & Tot) \\
\hline \multicolumn{1}{|c|}{ Total for all isotope shipments, including waste } & $8.2 \mathrm{E}-06$ \\
\hline
\end{tabular}

(a) Caculated impacts are for round trip distances

(b) Not applicable to Ac-227, Ra-226 target material is at the 325 Building.

(c) No travel in urban population zones

(d) Shipments from Boston Airport to Du-Pont (2.8E-04 fatalities)

Shipments from Chicago Airport to Amersham (4.3E-04 fatalities)

Shipments from St. Louis Airport to Malinckrodt (1.4E-04 fatalities) 
HNF-1844, Rev. 0

\subsection{REFERENCES}

10 CFR 71. 1993. U.S. Nuclear Regulatory Commission, "Packaging and Transportation of Radioactive Material." U.S. Code of Federal Regulations.

49 CFR 173. 1993. U.S. Department of Transportation, "Shippers - General Requirements for Shipments and Packages." U.S. Code of Federal Regulations.

49 CFR 175. 1993. U.S. Department of Transportation, "Carriage by Aircraft." U.S. Code of Federal Regulations.

Adams, K. G. 1990. Literature Review of Crud Spallation Source with Application to a Nuclear Repository. SAND90-0365. Sandia National Laboratories, Albuquerque, New Mexico.

Clarke, R. K., J. T. Foley, W. F. Hartman, and D. W. Larson, 1976, Severities of Transportation Accidents, Volume 1 - Summary. SLA-74-001, Sandia National Laboratories, Albuquerque, New Mexico.

Dennis, A. W., J. T. Foley, W. F. Hartman, and D. W. Larson, 1978, Severities of Transportation Accidents Involving Large Packages. SAND77-0001, Sandia National Laboratories, Albuquerque, New Mexico.

Fischer, L. F., C. K. Chou, M. A. Gerhard, C. Y. Kimura, R. W. Martin, R. W. Mensing, M. E. Mount, and M. C. Witte. 1987. Shipping Container Response to Severe Highway and Railway Accident Conditions. NUREG/CR-4829. U. S. Nuclear Regulatory Commission, Washington D.C.

Green, J. R. 1995. Transportation Impact Analysis for the Shipment of Low Specific Activity Nitric Acid. WHC-SD-TP-RPT-015, Rev. 1. Westinghouse Hanford Company, Richland, Washington.

Grove Engineering. 1996. MicroShield Version 5.0 User's Manual. Rockville, Maryland.

International Commission on Radiological Protection (ICRP). 1991. 1990 Recommendations of the International Commission on Radiological Protection. ICRP Publication 60, Pergamon Press, Oxford.

Johnson, P. E., D. S. Joy, D. B. Clarke, and J. M. Jacobi. 1993. HIGHWAY 3.1 - An Enhanced Highway Routing Model: Program Description. Methodology, and Revised User's Manual. ORNL/TM-12124. Oak Ridge National Laboratory, Oak Ridge, Tennessee. 
HNF-1844, Rev. 0

Madsen, M. M., E. L. Wilmot, and J. M. Taylor. 1983. RADTRAN II User's Guide. SAND82-2681. Sandia National Laboratories, Albuquerque, New Mexico.

Madsen, M. M., J. M. Taylor, R. M. Ostmeyer, and P. C. Reardon. 1986. RADTRAN III. SAND84-0036. Sandia National Laboratories, Albuquerque, New Mexico.

Napier, B. A., D. L. Strenge, R. A. Peloquin, and J. V. Ramsdell. 1988. GENII -The Hanford Environmental Radiation Dosimetry Software System. PNL-6584, Vol. 1 Conceptual Representation, Vol. 2 - Users' Manual, Vol. 3 - Code Maintenance Manual. Pacific Northwest Laboratory, Richland, Washington.

National Council on Radiological Protection and Measurements (NCRP). 1987. Exposure of the Population in the United States and Canada from Natural Background Radiation, Report No. 94. National Council on Radiological Protection and Measurements, Bethesda, Maryland.

Neuhauser, K. S. and F. L. Kanipe. 1992. RADTRAN 4: Volume 3 -- User Guide. SAND89-2370, Vol. 3. Sandia National Laboratories, Albuquerque, New Mexico.

Neuhauser, K. S. and F. L. Kanipe. 1995. RADTRAN 4: Volume 2 -- Technical Manual. SAND89-2370, Vol 2. Sandia National Laboratories, Albuquerque, New Mexico.

Pacific Northwest National Laboratory (PNNL). 1996. Safety Analysis Report for the 325 Building. PNL-SAR-325. Richland, Washington.

Rao, R. K., E. L. Wilmot, and R. E. Luna. 1982. Nonradiological Impacts of Transporting Radioactive Material. SAND81-1703. Sandia National Laboratories, Albuquerque, New Mexico.

Ross, 1994. Transportation Evaluation Report. Ross Aviation, Inc., Albuquerque, New Mexico.

Saricks, C. and T. Kvitek. 1994. Longitudinal Review of State-Level Accident Statistics for Carriers of Interstate Freight. ANL/ESD/TM-68. Argonne National Laboratory, Argonne, Illinois.

Taylor, J. M. and S. L. Daniel. 1982. RADTRAN II: A Revised Computer Code To Analyze Transportation of Radioactive Material. SAND80-1943, Sandia National Laboratories, Albuquerque, New Mexico.

U.S. Department of Energy (DOE). 1994. Department of Energy Programmatic Spent Nuclear Fuel Management and Idaho National Engineering Laboratory Environmental 
Restoration and Waste Management Programs Draft Environment Impact Statement. DOE/EIS-0203-D. U.S. Department of Energy, Washington, D.C.

U.S. Department of Energy (DOE). 1996. Medical Isotope Production Project:

Molybdenum-99 and Related Isotopes, Environmental Impact Statement, DOE/EIS-0249F. U.S. Department of Energy, Washington, D.C.

U.S. Environmental Protection Agency (EPA). 1988. Limiting Values of Radionuclide Intake and Air Concentration and Dose Conversion Factors for Inhalation. Submersion, and Ingestion. Federal Guidance Report No.11. EPA 5201/1-88-020. U.S. Environmental Protection Agency, Washington, D.C.

U.S. Nuclear Regulatory Commission (NRC). 1977. Final Environmental Impact Statement on the Transportation of Radioactive Material by Air and Other Modes. NUREG-0170. Washington D.C.

U.S. Nuclear Regulatory Commission (NRC). 1993. Directory of Certificates of Compliance for Radioactive Materials Packages. NUREG-0383. Washington D.C.

Wilmot, E. L. 1981. Transportation Accident Scenarios for Commercial Spent Fuel. SAND80-2124. Sandia National Laboratory, Albuquerque, New Mexico. 


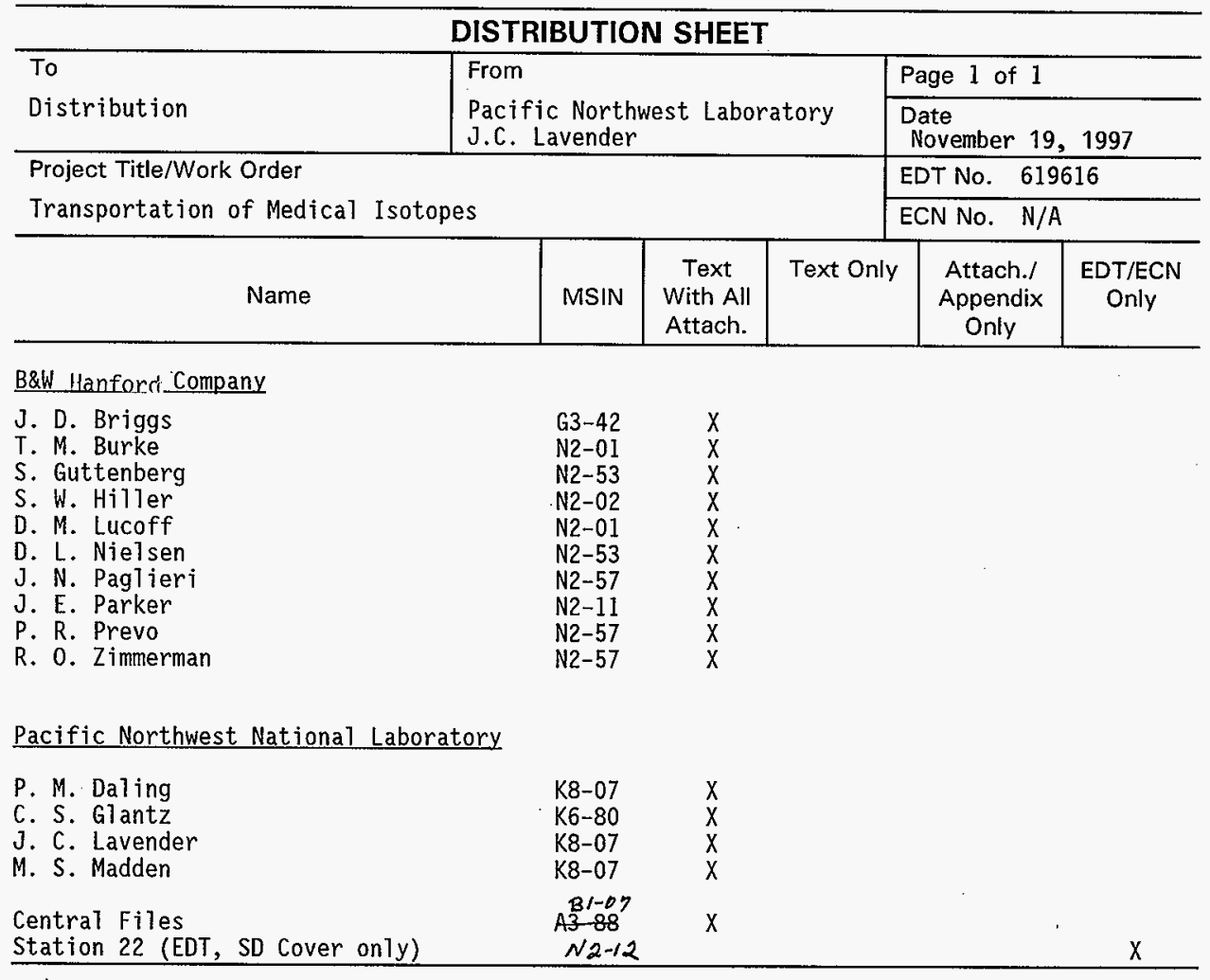

DOES NOT CONTAIN CLASSIFIED OR

UNCLASSIFIED CONTROLLED

NUCLEAR INFORMATION

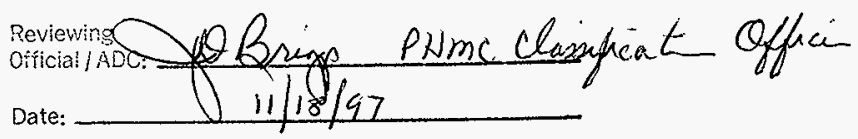

